


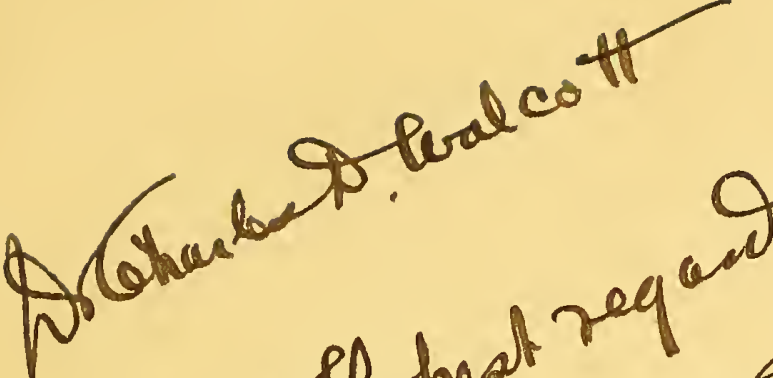

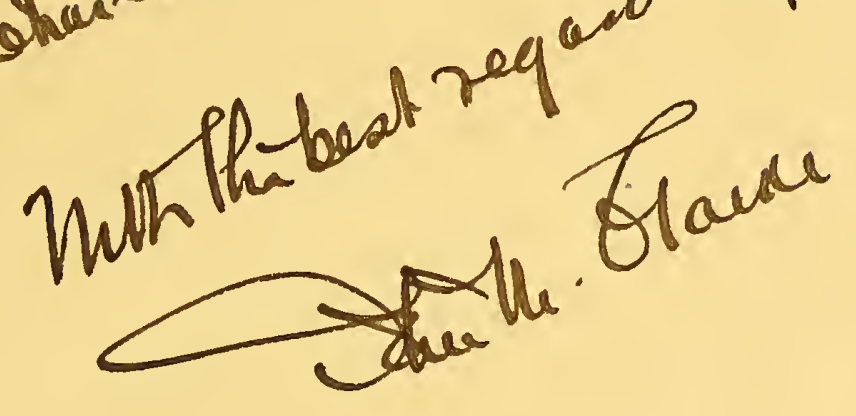



Organic Dependence and Disease. 



\title{
Organic Dependence and Disease: Their Origin and Significance.
}

\author{
By John M. Clarke, \\ D.Sc., Colgate, Chicago, Princeton \\ LL.D., Amherst, Johns Hopkins \\ Member of the National Academy of Sciences \\ New York State Paleontologist
}
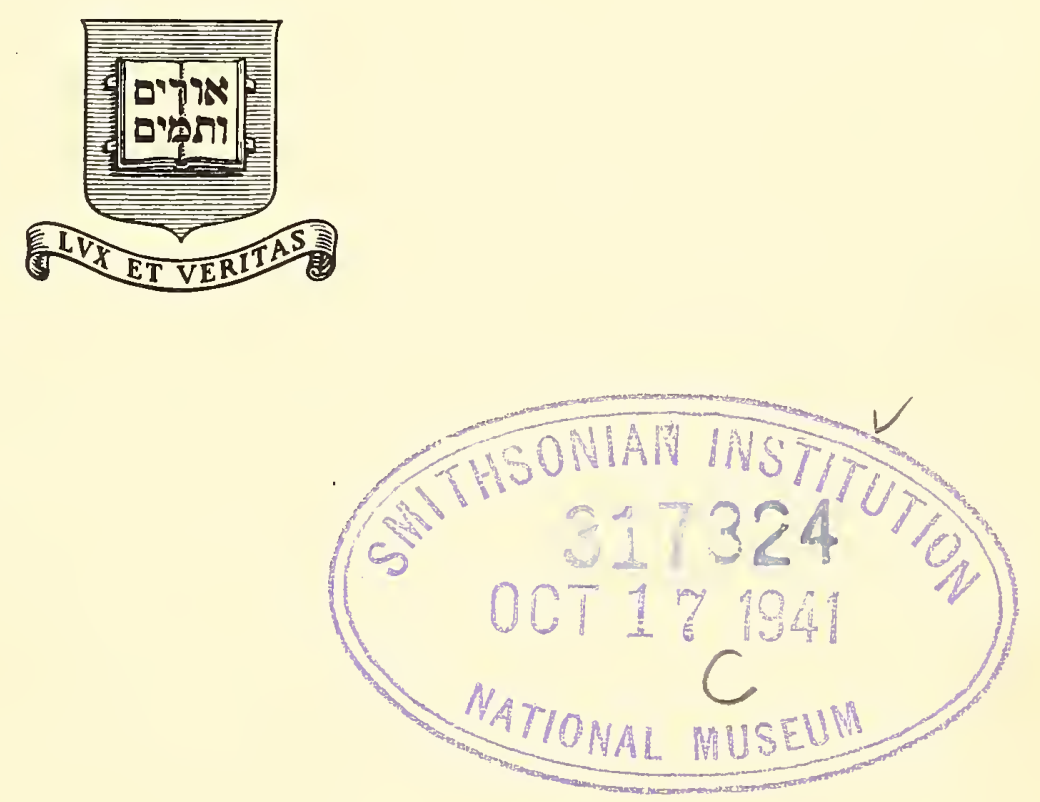

New Haven:

Yale University Press.

London, Humphrey Milford, Oxford University Press.

Mdeccexxi. 
Copyright, 1921, by

Yale University Press. 


\section{CONTENTS}

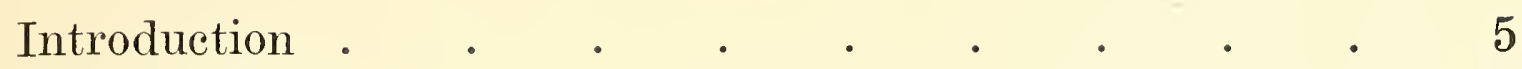

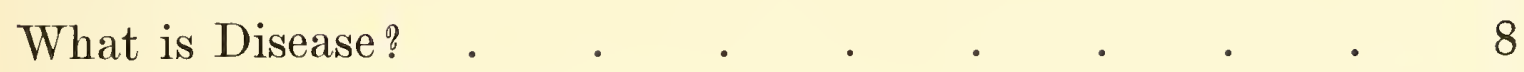

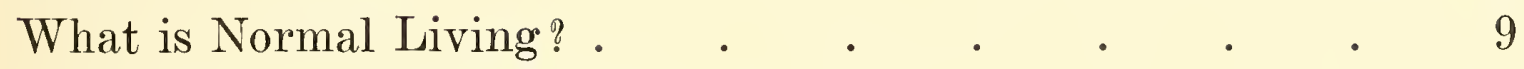

The Meaning of Abnormal Living . . . . . 10

Protective Covering a Basic Factor in Dependence . . 15

Proper Understanding of the Shell or External Skeleton 20

Stabilization, Longevity and Dissolution . . . . 23

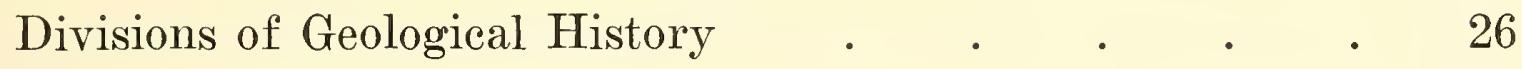

Independence of the First Fauna . • • • • • 28

General Survey of the Cambrian Fauna of North America • 29

The Cambrian Fauna Generally . . . . . . 32

Precambrian Life . . . $\quad . \quad$. $\quad . \quad$. 32

The Beginnings of Symbiosis and Parasitism . . . 35

Complex Character of Parasitism . . . . $\quad$. 37

Beginnings of Symbiosis . . . . . . . 37

Relation of Symbiosis to Parasitism . . . . 38

Illustrations of Primitive Parasitism $\quad$. $\quad$. $\quad$ • $\quad 39$

The Case of the Annelids . $\quad$. $\quad$. $\quad$. $\quad$. $\quad 39$

The Barnacles . . $\quad . \quad$. $\quad . \quad$. $\quad .61$

Early Parasitism of the Snails upon the Crinoids . . 64

Symbiotic Conjunction of Crinoids and Starfishes . 78

The Work of Pseudoparasitic Boring Organisms • • 80

The Distinction between Protozoan and Metazoan Parasitism 104

Sporozoan and Bacterial Parasitism in Geological His-

tory . . . . . . . . . 107

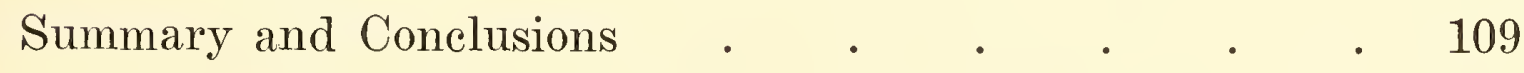





\section{Organic Dependence and Disease: Their Origin and Significance.}

\section{INTRODUCTION}

T

HE purpose of this essay is to set forth a basis of fact and reasonable inference bearing on the comprehension of the control which governs the historical origin of dependent and abnormal conditions in the living world.

The facts and their interpretations, together with their higher intimations as here presented, are based upon paleontological knowledge, that is to say, biological knowledge with the added element of unlimited time through which the life factors have worked. These are prime factors; they together remove our subject and its conclusions from the field of purely modern biology.

The knowledge we have little by little acquired in the special field-indicated by our title does not as yet make a great sheaf and it is not likely that the facts, in spite of their profound interest to us, can have any immediate value in the application of remedial measures in the correction of abnormal physiology. This statement is, however, not made without some reserve; a real clue to the inception of any abnormal physiology in nature must lead to interpretations of wide moment.

For a good many years the writer has endeavored to gather together from the earliest assemblages of life on the earth as preserved in the ancient rocks, such organic remains as might shed light, not primarily on the introduction of disease, as we loosely employ that term, but upon 
the existence and earliest appearances among these elementary expressions of life, of conditions which show an actual mutual dependence of creatures one upon another; that is to say, of the conditions commonly known variously as symbiosis, mutualism and parasitism. Such evidences are not easy to acquire among primitive forms of life as preserved in the rocks of the earth's historic record, but persistent and long-continued search with the aid of a variety of special procedures adapted to the extraction of the peculiar character of the material employed, enlarged by the inspection of many great museum collections and joined with the help of generous colleagues and the special support of the National Academy of Sciences, has resulted in even so much light on these significant paleopathologic problems as is here set forth.

The writer desires to present his facts without embarrassing detail and his conclusions without bias. In his own justification for both he may urge a long acquaintance with nature's modes in the preservation of such materials in the fossil state and reasonable familiarity, based upon comparative morphology, with the forms of life that go to make up the earlier faunas and floras of the earth.

It will be observed, and special emphasis is put on this, that these chapters deal with the lower forms of life, the invertebrates among animals and cryptogams among the plants. The actual outstanding evidences of pathological and traumatic lesions among extinct animals of the vertebrate type are not comprehended within this discussion as such phenomena are registered only among faunas of the earth too late and too specialized for our consideration. Such lesions have been noted by several students of vertebrate paleontology and most interestingly brought together by Dr. Roy L. Moodie, whose investigations into the history of such registered conditions and of the possible effect of disease in the extermination of races of the higher animals through the later ages of the earth are very suggestive to 
anyone concerned with the origin of our actual inheritance of specific pathological conditions. ${ }^{1}$

It hardly seems necessary to premise that pathological conditions, or diseases, to speak specifically, are as much a matter of evolution as the human hand or the bird's wing. The statement of so obvious a fact here would have seemed superfluous except for the sharp citation recently served upon his colleagues by an eminent physician, that "human maladies are but a narrow fringe along the border line of disease," " which would seem to intimate that repetitive emphasis may wisely be laid upon this statement.

In the ancient rock formations and the life assemblages with which we are here dealing there are few of these higher creatures, the vertebrates, and among them specialization in organs and function has gone so far as to becloud the record we are seeking to disclose. Here the effort is to take the simplest and least differentiated expressions of life conditions in their earliest appearance, before the living world had become so inexpressibly complicated as it is today or so indelibly stamped by the accumulated heritage of boundless ages. It may be said that these investigations, which rest upon the certain results of the laws of life, lead the reflective mind into passages tangent to human concerns of high moment.

We shall need for the immediate purpose a clear understanding of what is meant by disease, as the term is here used. Our employment of the word is a rather loose one; probably no physiologist or pathologist would be satisfied with it, if indeed the term could be adapted to modern pathological use. It has at best only a popular value and its application is without scientific exactness. Thus, tuberculosis

1 Roy L. Moodie. 1916, American Journal of Science, v. 41:530-31; 1916, Science, v. 43: 425; 1917, “Annals of Medical History,' pp. 374-93.

2 R. G. Eccles. "The Scope of Disease," Medical Record, March 8, 1913. The reader is also referred to Doctor Eccles's other important papers in this field: "Disease and Geneties," op. cit., August 2, 1913; "Parasitism and Natural Selection,', op. cit., July 31, 1909. 
is a pathological condition involving the normal growth of a living creature, the Bacillus tuberculosis. This condition is a disease only from the point of view of the host of the. parasite, that is, of the sufferer. To the parasite it is the normal, though adjusted, mode of life. This, however, is an advanced and complicated example whose history, when worked out, must be determined on the basis of causes producing such adaptation of parasite to host, and the study of such adaptations must always keep in view the ease with which adaptations have constantly been and are constantly being made. Let us discuss this matter more at length.

\section{WHAT IS DISEASE?}

We must answer this question in terms of the original use of the word-disease is discomfort; it is thus the early English writers employed it and we must not forget this simple meaning which is not observed in common usages. But in the specific application of the term to physical discomfort we shall find Huxley's definition broad and clear: "Disease . . . is a perturbation of the normal activities of a living body." In this expression by the great English physiologist there is a definite implication that disease means disorder of specific function, as we generally understand it. But the broader idea in this definition is clear; that disease is any departure from normal living. It may be a departure in a single function or it may involve several functions of physiology; and such an abnormal condition may permeate so many functions as to create a general impairment or maladjustment of the entire anatomical machinery. It is elementary, as well as scriptural, to say that seldom can one organic function become impaired without involving others, for no member of the body can say to another, "I have no need of thee."

There is, however, a still broader conception that we can draw from Huxley's definition and which is of the first im- 
portance for our purposes. It is this: That the entire body, organism or creature and the entire race or stock to which it belongs may become abnormal through subjection to an abnormal or perturbed mode of life. Such body, creature, race or stock is therefore in a state of disease.

This condition has so frequently entered upon the life modes of the animals and plants as to form an essential basis of their classification and it is the mightiest single influence in the separation of them into grades of excellence. We hesitate to call such animals and such entire races of animals and plants "diseased," but their mode of life is obviously disordered and we have no choice but to term it abnormal and consequent upon a "perturbation of normal activities." Illustrations of this will presently be given.

\section{WHAT IS NORMAL LIVING?}

With the help of the light drawn from a study of the early faunas of the earth, that is, the assemblages of animals which were the first to people the salt waters of the ocean, we can find an answer to this question which I think would hardly be fully possible from the study of existing animals alone. Normal living, in the broad sense in which we desire to be understood, means full activity of an unimpaired physiology inclusive of the function of locomotion or mobility. This is not a very complete definition as it leaves out of consideration the primitive development of the locomotive function, which must have worked itself out gradually just as other organs have developed in response to the demands for their functions. Except for that, the definition does very well, and it implies that normal living means independent living; it means that every creature which is in itself a perfect physiological mechanism and has in itself the essential basis of progress in grade, in which lies any "hope of salvation," must maintain to ma- 
turity an independent life, whatever may happen to it in the period of its waning.

At the risk of stating our conclusions before we have fully marshalled the evidence, deductively, then, normal living is, in terms of biology, correct living, that is to say, righteous living, and in so far as dependence invades the mode of life whether in organ or individual, such living is unrighteous, disordered and diseased; in better phrase, biologically, is without hope, for such perturbation or disease is beyond voluntary or casual rectification. These ideas apply not to the individual only but to the species, the race, the stock, even to the broadest divisions of life, the subkingdoms themselves.

In speaking thus of dependent life as an expression of perturbation of function, it is easy to fall into misapprehension, for in writing on the subject of parasitism the mind of the reader is likely to turn involuntarily to the overwhelming invasion of all the earth by protozoan and protophytic parasites, parents of "germ diseases" and infestations, sponsors for the deadly assaults upon humanity whose victims count up more than all other causes of death combined. We shall presently endeavor to indicate the elemental and historical differences between such unicellular parasitism and metazoan parasitism; the latter involving the mutual somatic relations of multicellular differentiated and well-defined animals or plants. The present statements are made with special reference to metazoan dependence.

\section{THE MEANING OF ABNORMAL LIVING}

From the world about us volumes have been filled with examples of these departures from the normal mode of living. It is safe to say that a vast majority of all life of the world is permeated by this loss of original excellence, which is, in more explicit terms, a condition of dependence and degeneration. We can not get a more impressive conception of its effect throughout all nature than in its elemental ex- 
pression; the primary division of the whole kingdom of life is based upon the interpretation of this fact. Let us consider the plant world, the trees of the forest and the lilies of the field. They are clothed in a majesty and beauty before which the attainments of the animal kingdom pale. In the earliest life ages of the world, the days that geologists have called the Proterozoic, the multicellular progeny of the earliest unicellular beings whose simplest beginnings we are slowly coming to know, determined through adaptation the entire subsequent course of life upon the earth. With our present understanding I believe it safe to say that the career of the life record on earth was laid down, "conceived in the lowest parts of the earth," when some of these progeny found it to their material advantage to anchor themselves and to draw sustenance out of the soil or sea bottom where they stood, while to other's fell the lot to seek, or being of more pronounced excitation and reaction, chose to seek their food from place to place. Those became dependent, the latter retained their independence; and there came the great cleft in the world of life, a cleft so deep and so enduring that time has had no power to heal it. A great tree may well be of more service to the community than a man, some human derelict, but a tree will never become a man, nor anything else than a tree. In all the bewildering developments of the plant kingdom in which we find organs and fluids for the digestion of flesh, organs of special sense implying a nerve system that yields to and perhaps interprets the impacts of touch and of light, functions which have led undisciplined philosophers to the fancy that this apparent assumption of special functions indicates a refinement of anatomy which approaches the bridging of the abyss between plant and animal, the plant in its most impressive attainment still remains anchored and rooted, sometimes tossed about or floated by the waters but essentially devoid of independent motion.

The significant fact, supported by the most tangible and 
obvious of evidence, of the primitive divergence of the two great subkingdoms of life, lays elemental emphasis on the distinction between normal independent living and abnormal dependent living; between what we may with perfect propriety term, in biological sense, right living and wrong living. Out of the first of these groups have come all the great triumphs of life; the races of life which, by keeping individual and racial independence, have persistently climbed upward. The second group has been hampered and rooted from the beginning, hopeless of ever throwing off its chains or of arriving at any end beyond a certain refined functional specialization within its own limitations. The giants of the redwood forests are the hoary and venerable obelisks of power shackled beyond redemption; the gardens of flowers are blossoms of a hope never to be attained. In any sound philosophy of nature this great fact, even though its inceptive cause is still veiled to us, must lie close to the base of all deductive reasoning. Lest these sentences be suspected of a teleological taint, let me express the conviction that, in any interpretation of such phenomena as those here considered, the materialistic formulas of adaptation and subjection to environment give way to recognition of purposeful activity which can be interpreted only in terms of psychology.

As there are evidences of limited freedom in the plant world (as in the amoeboid movements in the Slime-fungi, the Flagellates and many Bacteria) so, by contrast, the animal world is shot through with races of dependent creatures, and in so vast degree that it may safely be said the foundation races of animal life, the invertebrates, have in greater or less measure fallen by the wayside in the course of their journey through the ages; few indeed have kept to their charted course and to these few, linked together in the successive ages of the world, following one upon the heel of another, we owe all the enduring progress and attainment which our present life has reached. 
On this point our present knowledge permits us to lay emphasis, namely, that on the whole, in the survey of the earth and the sum total of its multitudinous and inconceivably variant groups of life, there has been a strong minimum, a redeeming minority, of competent upward evolution; and wise students of nature, in reflecting on this thought, have broken out into exclamations of wonder and amazement at the slender thread of chance by which we who call ourselves men have come to this estate, in a world where for millions of years the temptation to the easier way and the obstacles to independent living were constantly against us.

Let us look at a most common illustration of the general fact of dependence among existing races of animal life, of very ancient ancestry. The oyster is early attached firmly to the sea bottom, to the rock or to the shell of a brother oyster and never stirs from its moorings for the rest of its life. It opens its hard valves a little way to let its servants, the food-bearing water currents, deliver their nutrient supplies and it defends itself in the struggle against enemies, not by standing out in the open and meeting force with force but simply by closing its doors and shutting itself up in its calcareous caisson. To the attacks of sharptoothed fishes and the relentless starfish the oyster has little defense. The nonresistant, flaccid, pacific creature within, fully equipped with the organs of special physiology, is essentially the same in habit as he was those millions of years ago when the oysters began to show themselves in the salt waters of the Carboniferous age. The knell of its progress was struck when first it settled down to a fixed immobile existence and, hopeless as the ox, the future holds for it no promise of improvement. And yet even today the embryo oysters have a brief period of locomotive freedom, proof enough in the laws of ontogeny that a free life was once the ancestral condition of the race. With the oyster's cousin, the clam, the case is similar ; less degenerate in phys- 
iology than the oyster and very rarely attached solidly to the sea bottom, yet the same degenerative effect upon the animal has been produced by burying itself in the mud with only the tips of the valves or a pair of fleshy tubes extruded upward to reach the moving food supply in the water currents, while the burial helps out in large measure the defensive purpose of the solid armature of the shell. The clam is a much older creature than the oyster and in specific functions it has, broadly speaking, degenerated less, but it serves to bring out the important fact that the habit of burial in the mud, from which it does not easily release itself and never for long, is tantamount to fixation and involves the organic stagnation in which these creatures have lain for ages which can not be counted. This is hardly the place in which to restate well-known paleontological facts, but such cases as these and the extensive catalog of like instances must serve to remind us that such adjustments, early formed and perduring through the ages, have been attended with the least possible variation in proportion as the adjustment is perfect. The longest lived of all creatures, then, are those which have lived in most perfect adjustment and in which therefore readjustment is most hopeless.

We have very direct evidence of the early formation and long endurance of specific habits of life in these adjusted dependents. The starfish of the Devonian age fed upon contemporary mollusks in the same way and by the same mode of attack that the starfish uses today upon the oyster's of Long Island sound; surrounding the tightly closed valves with their strong-armed rays, pulling steadily against the strained muscle contraction of the mollusk until the weary shell-fish, muscularly tired out, gives up, the valves relax and open and the extrusive maw of the radiate enters. ${ }^{1}$

\footnotetext{
1 Clarke. Jour. Acad. Nat. Sci., Philadelphia, v. 15, 2d ser. Centenary num-
} ber. 


\section{PROTECTIVE COVERING A BASIC FACTOR IN DEPENDENCE}

A knight in armor is a protected fighter and by his protection increases his viability. A man "on his own," who fights with his "dukes," risks his viability but nevertheless increases his physical vigor and exalts his bodily prowess. A recent writer on the morale of our army in France brings out the fact that a man who could defend himself with his fists made a better soldier than the one who depended alone on the weapon he carried in his hand.

Nature has given to a large part of the animal world one or the other of two solid supports for the soft organs and flesh of the body; an inside skeleton, like that on which our own soft anatomy is hung, or an outside skeleton or shell, to which we may here give special attention. I have used the expression, nature has given, meaning that the necessity of support to the body having early shown itself, such supports developed in response to external impacts and internal stresses; the historical course of development of these calcareous supports makes the fact sufficiently obvious that they are a determined sequence and not a chemical reaction or a casual device.

A rhizopod, a speck of soft protoplasm with the marvellous special function of eliminating the silica from its solution in the sea, exudes this mineral matter in the form of an outside shell of wondrous delicacy and symmetry. The unprotected soft tissue in the primitive ancestry of all the great tribe of the Mollusca or shell-fish, tossed haphazard on the sea bottom and hopeless against attack except through concealment or powers of rapid self-propulsion, acquires the special function of eliminating from the sea the salts of lime, carbonate or phosphate, and with them builds up its outside shell. We have just noticed that even today the young of such hard-shelled mollusks, in stages when their shells are but beginning to grow, are free swim- 
mel's for a while; their ontogeny or individual history here, as often, reflecting the successive phases of development through which their entire race has come.

This ontogenetic fact referred to is so generally repeated in other groups of the lesser animals that it may safely be said of all which live their mature life encased in shells or moored to other objects, that it is in their infancy alone their normal life is expressed, and we know as well that the pervasion which has set in to change a life of freedom and independence has likewise set up changes of anatomy and physiology which make the mature creature only the more dependent by adjustment to his abnormal life. The development history of the individual is an important record for interpreting the status of that individual, whatever kind of creature he may be. The boy is father to the man in a very true sense when we apply it to ourselves or to any animal that keeps its independence throughout life. But the boy, the young, the infant stage, is the only faithful reflection of the dignified past in the case of such creatures as have lost their grip on normal living and have resorted to the sheltered life.

With these statements of cause and effect it is easy and natural to ask and answer once more that venerable question whether the perfection of life lies in the perfection of adjustment. Independent living, freedom of locomotion and range expose the individual to ever new dangers. These the individual must quickly overcome or outwit; otherwise succumb. The choice is quick, imperious and final. To live is, for such independent creatures, an escape or a victory. To call it a "struggle" for existence is to designate it subjectively but very often it is exactly that, a quick reaction of refined innervation or "wits," of the weak against the strong. But to the larger problem, that of those which have sought and found the easier way and which have snuggled into personal comfort, as contrasted with the struggles of the pathfinders of creation, there are 
many angles of approach. The common clam is the perfect adjustment; buried in the mud and fortified by its coat of mail it is difficult to find a creature better adapted and protected. It is a natural sequence, then, that the race of clam has abounded in all the seas since almost the earliest ages. Again, the pea crab hides himself in the living oyster, and the hermit crab backs himself into an empty conch-shell or periwinkle, hiding away his soft degenerate abdominal joints and tail and using the mouth of his bombproof for offensive as well as defensive purposes. Neither of these inquilines comes out; neither would dare to expose his softened mature body outside; but his adjustment is competent notwithstanding the fact that he is a degenerate whose ancestors were hard-shelled and who, succumbing to the outside struggle, found this protection inside the shells of the mollusks. The paleontologist Ruedemann has beautifully shown that far back in Ordovician time or earlier, the acorn barnacles, whose hard-shelled descendants of today coat the submerged reefs of the sea and the hulls of befouled ships, were derived from the free-swimming crustaceans of the phyllopod type, through attachment by their backs; a process which seems to have started first as a partial burial of the carapace, leaving the food-grasping organs and gills exposed above the mud; eventually becoming an actual solid fixation because of the distinct advantage in protection and ease of feeding which the animal had discovered. Lateral stresses, Ruedemann thinks, the play of the currents against the carapace and the strains against its side walls, developed the sutures which divide the peculiar shell of the Acorn barnacle. The other great class of barnacles, Lepas, or the commonly known Goose barnacles, whose clusters are found today in places where the other barnacles grow, seem to have had a like origin at a like period of earth history, through a cementation, not by the back of the phyllopod ancestor, but rather by its head. These are most venerable degenerates of most adequate adjustment. They 
started so many millions of years ago that a half of the whole period of life on earth has passed over their degradation and the whole race to which the barnacles belong, the entire class of cirripede crustacea, have taken this course. With a thousand like cases, they speak only of extreme adaptation of their physiology to their adjusted requirements. Substantially protected, their longevity has been thereby ensured. We do not need to raise the question as to whether these protected and adjusted creatures have been the source or starting point of any progressive development in the animal world, for they are, as we have said, the most obvious degenerates, out of which nothing better has been derived and from which nothing can be hoped for; on the contrary, which are moving slowly under their protection into an ever more hopeless state. Examples quite as explicit in their teaching permeate the more progressed groups of life. Here we are dealing with the simple and less specialized because in them the laws of life can be read most clearly.

It would be trite to say that a perfectly adjusted life is an unprogressive one. The adjusted life makes for conservatism and reduces the chances of variation to its lowest terms. It stabilizes the organism in all its physiology; it anchors the type. Speaking for the moment in higher terms for the individual the adjusted life is likely to carry with it the highest content of happiness. To progress in organic development it is the undeniable foe, but to the conservatism of intellectual and spiritual ideals the undoubted friend. In the reading of this law of adjustment we must estimate its worth in terms of the end subserved.

Today the world is rattling with uneasiness; it has entered a period of explosive evolution in human ideals directly comparable to the compulsions which again and again in the history of life have brought quick climaxes and acute outbursts of culmination after slow ages of ac- 
cumulating dynamism. The parallel is a true one. The insects branched into being from out of the scorpion stock of the early Paleozoic age. Slowly they made their way ahead, attaining the endowments of agility which life in the air imparts; quick nerve reaction and refinement. Suddenly today they have reached a point where their intense vitality is an actual menace to the mammal life on the earth, whose future salvation seems in no small measure to be up in the air between these insects and their aërial enemies, the birds. The great reptilian bubble swelled up and burst in the days of the Jurassic and Cretaceous periods, leaving behind a few crocodiles and lizards for today, and that great agile race of highest variability - the birds. The alligators and salamanders and their scattered kin alone retain the type of structure so painfully worked out through the long ages before the days of the collapse and there is no chance, not the faintest promise in the history of Nature that she will, in such an earth as has now come into being, again experiment with this type of structure. Out of the crash of the reptilian overgrowth and extravagances only the birds seem to have emerged with a promise still ahead. Our own stock, the line down which we have come, travelled clear of these excesses in development, and while the reptilian blood is in mankind it is not that of the reptilian climaxes, the dinosaur or the brontosaur. It is the surest thing that the minorities of those ancient days saved the day for us. And in the convulsion of ideas which has burst upon the present world through the lifting of the lid to pent-up and restrained bizarreries of impulse, there will remain behind, if Nature is true to her standards, a stalwart conservation of the type, minority though it may be, which has been worked out through the ages and in which must lie the enduring germ of future advance. The froth is a scum of bubbles, the relief of a tension it is well to be rid of. 
The Proper Understanding of the Shell or External Skeleton. It is well recognized throughout the evolution of organic beings that a feature acquired as an advantage in the fight for existence is easily carried beyond the point of advantage into a disqualification or obstacle in the same struggle. The elephant's tusks, the narwhal's horn, the moose's antlers, the sabre-toothed tiger's canines, bony collars and dorsal crests in the ancient reptiles, stony spines on head and body in infinite variety among invertebrates, are ready representatives of this fact. It is specialization-development carried from usefulness into disadvantage. The hardening of the outside coat of primitive organisms or the creation of an external shell was, in its inception, a definite protective advantage so adjusted by secretion that it could not impair the activity of any function. In many of the simpler expressions of life, the Radiolaria, the Foraminifera and sponges, these mineral deposits were not permitted to interfere with the easy movements of the protoplasmic or simple cell contents, and so if the scattered mineral particles became united into a solid framework, there were definite openings and holes left for such movements. As networks of minute rods or stars or little burrs, or in other forms of beauty and symmetry, built up by an unexplained directive process, the mineral matter is often disseminated through epithelial or epidermal walls, as in the sponges, or compactly joined together into definite continuity, as in the corals. The starfish and the crinoids have aggregated the skin deposits about centers out of which growth has often developed solid plates which press against one another without uniting and so produce a covering with some degree of elasticity.

In the type of external skeleton shown by the mollusks, to which we have referred, the clam, the snail, the nautilus and their allies, the epithelium or mantle builds up by spicular calcification a hard continuous covering which actually embraces or is competent to embrace the entire animal; an 
impenetrable and typically unjointed armor. ${ }^{1}$ With them is to be grouped the vast army of brachiopods which thronged the early seas of the earth, a group whose organic station has been much debated, whose historic position and anatomy separate them too widely from the mollusks to justify speculations as to their degeneration or derivation from that stock.

This form of protective covering represents almost the extreme of defensive personal armor; a complete adjustment accompanied by, or resulting in, a stabilized inheritance. All groups of the Mollusca have not permitted this development to go to so great an extreme as in the lamellibranchs, or clams, for the snail and the nautilus travel about carrying their coiled shells with them, quick to withdraw into them whenever danger comes and often to close the door behind with a shelly plate or hardened skin. Squids and cuttlefish, late representatives of the nautilus stock, have followed a divergent path in this development by which their outer shell has been enfolded within the body substance. These creatures, too, maintain an active mobility, flying like darts through the ocean waters. Pteropods, a very ancient and active molluscan type, and the translucent scaphopods are the surface swimmers of the deep seas. Both carry light external shells and all these together seem to portray the result of long struggle against the general enchainment of their class and to typify in a measure what the Mollusca might all have been had not subjection of close encasement been sought or thrust upon them. Among them all, the most palpable change, progress and variation of expression are within the active groups.

A very much less seclusive body-cover was developed by the great group of articulated animals, the Arthropods, represented by the shrimps, crabs, lobsters and insects. In

1 Except chiton and such multivalvular mollusks, whose articulated shell appears to be a response to the coiling habit which the animal had in much the same degree as the trilobite and the sow bug. 
simplest expression such animals are constituted of a succession, from head to tail, of a series of transverse body segments, each of which is to be interpreted as a somatic unit. Specialization among these somatic elements early appeared by adaptation to definite functions, and advance in specialization was followed by coalescence of the anterior segments as we see them in the carapace of the lobster or the head of the trilobite. But regarding this type in its inception, we have to deal with a repetitive series of elementary like parts, comparable only to and probably derivable only from the ancestral segmented worms. The epithelium of this group was so vitalized that it could eliminate from the water carbonate and phosphate salts of lime, combining with them a certain proportion of organic matter which may have been in part derived from the epithelium itself. Thus we find the members of the group for the most part thin-shelled, with the shelly cover of plates delicately jointed one with another, so that the motion of the parts, except for such as are fused together, and of the appendages of the parts, similarly covered and jointed, is in no way impeded. And in the normal expression of these creatures there is no impairment of locomotion.

This is a protection by an exoskeleton which is a perfectly advantageous adjustment, as it involves no interior constraint of organic function. The arthropods may put on an infinitude of shape and be found adapted to all media of life; they may present innumerable expressions of extreme degeneracy, subservience and adapted solid protection acquired by boring or burial; but in all these conditions the type of epidermal protection is not fundamentally altered.

The external shell on any creature, whether snail or soldier, is then a structure which, in the idea and the inception, helps, not hinders, in the fight against untoward conditions. Kept in subjection to the high function of locomotion, it has accelerated and helped to ensure progress. Used intem- 
perately and in easy surrender it has exceeded its first purpose and finally walled up its owners against a fighting chance for improvement.

\section{STABILIZATION, LONGEVITY AND DISSOLUTION}

Over and over again in the history of the earth we find the evidence of a methuselan stability among living creatures, usually shown in definite species but sometimes permeating an entire assemblage or fauna. Ruedemann has shown in great detail the extraordinary number of conservative types or "radicles" which have been perpetuated through the geological ages. It is a remarkable rôle of delinquents. ${ }^{1}$

Such illustrations as these will serve: There are the protoplasmic Foraminifera which appeared in the Ordovician and Silurian and have kept their generic characters over the lapse of millions of years, to the best of our knowledge, into the present seas (Saccamina, Lagena, Nodosaria). The brachiopod Lingula lives abundantly in the existing seas; its life began in the early Ordovician, and though students of this group believe they see some divergence in structure between the ancient and the existing Lingula, yet the type is but slightly altered and the line is unbroken over this enormous range of the ages. The brachiopod Crania has had a like career, and another brachiopod species, Leptad . rhomboidalis appeared in the Ordovician seas and continued as a specific type through the Silurian, the Devonian and Carboniferous, thus caught in the world-wide continental disturbances which brought to its close the long Paleozoic era. It varied indeed within limitations but retained its essential specific character's without dissolution for a period probably ten thousand times as long as the

1 R. Ruedemann. "Paleontology of Arrested Evolution'; Presidential address before The Paleontological Society. (N. Y. State Mus. But. 196, 1916, pp. 107-34.) 
Christian era. It would be only a long guess to tell why Leptaena rhomboidalis lived long and was more quickly adaptive than others of its congeneric associates. Not a feature of structure observed or deducible points to the explanation. Another brachiopod, Atrypa reticularis, lived through the millions of years from the Silurian into the Carboniferous with but indifferent modifications of its specific type. Some paleontologists may say that these statements fail to recognize the chronologic differences in these stabilized types, and that to identify living Foraminifera, for instance, with those of the Mesozoic and of the Silurian is hasty and incompetent. It is an a priori statement without demonstration. For the brachiopods at least, the Lingulas, the Leptaenas, the Atrypas, the fact remains after careful scrutiny that the differences have not proved permanently translatable in terms of time and change, are hence negligible, and that other distinctive generic names that have been applied to them are not of much account. These are long-lived creatures, and, while exceptional in their longevity, we must try to realize that by virtue of structural and functional constitution they acquired an adjustment or resistance to change which made them as nearly permanent and as completely stabilized as life, it would seem, can ever become. Their endurance without change can be expressed only in millions of years. Armored or protected, they were the more competent for this long life. But even Methuselah died, and Leptaena rhomboidalis died at last, as a species, through some revolutionary maladjustment which would no longer permit its endurance. These are patriarchal life periods; but for the multitude of species of the past that have kept their characters unaltered through a single geological system or a major subdivision of it, we must think of their days in thousands of thousands of years and not in any terms of easy conception that we might use in our conventional expressions of time. 
There is also a stabilization that affects an entire fauna when the members of the assemblage are all in balance with their external and internal control; and so a single fauna may endure for a long period without change of complexion. Thus the invertebrate shelled fauna of the Mississippian or Lower Carboniferous marine limestones which spread over Colorado, New Mexico and northern Texas, shows such uniformity of character through a very long lapse of time; and in the Middle Devonian Hamilton period, when shallower water prevailed, there is a similar continuity of organic character without variation, throughout nearly a thousand feet of shale which must represent a period of many thousand years. The fauna must, however, eventually succumb, that is, yield by evolutionary or intrinsic variation, or by extrinsic change; shallowing or deepening of the sea, change of climate, a hundred outside influences, to its surroundings; just as many of the long-lived species must yield, or at any rate have yielded, to a resistance too great even for their conservatism to overcome. It is again to be emphasized that it is protected, encased and immobile life alone that achieves such long endurance; the conservative and sheltered types. The mobile and locomotory animals have at no time in the earth's history evinced long life without change.

These conclusions are so well established that we may rightly look to them for light upon the interpretation of certain tendencies to rest and unrest, conservatism and impulsive change, in human society, and while it may not seem very appropriate to speculate on the further bearing of this theme, it must be said in looking back over the field of organic history, that the value of the product must be in terms of the worth of the type conserved or broken; that is, worth in the sense of highest attainment in functional grade and in the approach to mentality. In such a sense a lobster is better than an oyster because it is of a vastly more refined grade of structure; and though the oyster has 
had the longer life, its type was locked up almost from the start, and except for the lesson it teaches of stagnation and decline, we might say, without impiety, that its conservation has been a waste of time. And it is a type, too, that was won, not by the arduous struggles of the ages, but arrived at early and with ease. Therefore its lessened worth.

\section{DIVISIONS OF GEOLOGICAL HISTORY}

We cannot well proceed with this discussion without a succinct statement here of the stages of geological history, in which special emphasis is laid upon those earlier divisions with which we are especially concerned. The table that follows is a condensed one of standard acceptance; it begins at the top of the latest life-bearing rocks and ends with the oldest. As to the estimates of time represented for the deposition of these sediments and for the existence of the life of the earth, this must be said: Ten years ago there was considerable variance of opinion between the physicists who were estimating the age of the planet on the basis of the external disturbances to which it was subjected in our planetary system, and the geologists who sought to approach this problem from measurements of the rate of deposition and erosion of water-laid sediments ; but a conservative conclusion had been provisionally attained which was tacitly accepted by most geologists as somewhere between sixty and one hundred million years for the sum of all water-laid rocks and perhaps from forty to sixty million years for those rocks which still carry the obvious remains of life. Since the discovery of radium and with a growing understanding of the significance of radium decomposition and radio-activity these estimates have been enormously outstripped, so vastly indeed that the very size of the figures seems to put them under suspicion. The time element in this is still a factor of much discussion and 
ORGANIC DEPENDENCE AND DISEASE

TABLE OF GEOLOGICAL DIVISIONS ADAPTED TO NORTH AMERICA

\begin{tabular}{clll}
\hline \multicolumn{1}{c}{ ERAS } & \multicolumn{1}{c}{ AGES } & PERIODS & \multicolumn{1}{c}{ CHARACTER OF LIFE } \\
\hline Psychozoic & Recent & Rise of intelligence and age of man. \\
\hline & Quaternary & $\begin{array}{l}\text { Pleistocene } \\
\text { (Glacial) }\end{array}$ & $\begin{array}{l}\text { Successive glaciation, wide extinction } \\
\text { of life through cold, followed by quick } \\
\text { readjustments and rapid evolution. }\end{array}$ \\
\cline { 2 - 4 } Cenozoic & Tertiary & $\begin{array}{l}\text { Pliocene } \\
\text { Miocene } \\
\text { Oligocene } \\
\text { Eocene }\end{array}$ & $\begin{array}{l}\text { The vertebrate stock approaches phys- } \\
\text { ical culmination; obscure mammals } \\
\text { achieve the erect position. The earlier } \\
\text { mammals are of simple type. }\end{array}$ \\
\hline
\end{tabular}

Diminutive and primitive marsupialUpper like mammals continue to the close of this period and start upon a specific Cretaceons upward progress. Lower after having governed the earth in infinite variety.

Mesozoic The reptiles at maximum development. Jurassic In the period of their earlier and more plastic expressions birdlike reptiles developed and started the race of birds, LWhile their origin-stock is represented

Triassic by the primitive dinosaur reptiles. Here are the first traces of the mammal stock.

Permian

Climax of Cryptogamous plants. Land

Carboniferous reptiles and Amphibians fully established. Stalked Eehinoderms (erinoids) at their maximum.

Cnlmination of lung and armored fishes

Devonian and primitive sharks. Beginning of forests.

Paleozoic

Silurian

Scorpionlike arachnids (Eurypterida) at their maximum.

Ordovician

Reign of invertebrates of all stocks, largely affected by dependence and loss

Cambrian of function except in Cephalopod mollusks and Crustacea, but locomotive independence was more generally retained in the older faunas.

Proterozoic

and

Archeozoic

Worms, Radiolaria, Calc-algae, Bacteria. 
study; it is too soon to determine its value and to discuss it here is inappropriate, but we must at least grant to these suggestions the probability that we have heretofore greatly underestimated the time required for the upbuilding of the fossiliferous rocks and for the evolution of life. In terms of millions of years time becomes incomprehensible and the sum total, whatever it may be, must be regarded as competent for all the evolutionary processes of life and work.

\section{INDEPENDENCE OF THE FIRST FAUNA}

We still stand in ignorance of the real primitive or inceptive fauna of the earth, and when we use the expression "first fauna," it is with the reservation which absence of facts compels. We may speak freely, however, of the first fauna known to us and with a fulness of knowledge that justifies, in good measure, deductions regarding the nature of its ancestors upon earth. The fauna of the Cambrian system represents to us the actually known first fauna, for evidences of organic life in the rocks before and below the Cambrian are desultory though positive. While we are considering the special nature of the Cambrian fauna from the point of view we have here taken, let it be not forgotten that this so-called "first fauna" must have been millions of years in the making, worked out by the slow and arduous advances with which first steps have ever been taken in the course of nature. Our "first fauna," then, is also the product of the ages; and in spite of its complexion of simplicity, the entire absence in it of the vertebrate type and of what we are wont to regard the more progressed of its invertebrate types, specialization in anatomical structure is perhaps, in view of our expectations, the most obvious fact that it sets forth. Let us keep this important fact in mind as we study its composition with reference to independent and dependent life. 


\section{GENERAL SURVEY OF THE CAMBRIAN FAUNA OF NORTH AMERICA}

The present registry of described species is now about 1200 , and they range from algae to crustaceans and annelids. This statement fairly represents the span of life in this fauna. It is a reach from an expression of perfect function with minimum of structural differentiation, as in the sponges, to the specialized organic structure of the trilobite.

Of the 1200 species, one-third (373) are brachiopods. Brachiopods are animals which we believe to be derived from a stock similar to, or identical with, that out of which the worms have come; and it is quite certain that the longlived "inarticulate" brachiopods represented by Lingula, retain pretty definite annelid resemblances. A vast number of Lingulas occur in this fauna and their form of attachment, if comparable with the living Lingula anatina, was like that of many contemporary worms-a burial in the mud, rather than a fixation to the sea bottom. The great array of Cambrian brachiopods presents at maturity a minimum of fixation by means of the pedicle, which was an organ not homologous with the byssus by which the mussel shells are attached but an adapted organ obviously of a different original function. Throughout the later Paleozoic story of these brachiopods, attachment by the pedicle was easily surrendered, and solid fixation by the substance of the shells easily assumed. The fact is to be emphasized that the brachiopods are a distinct order of creatures with no affiliations with the Mollusca and none except in semblance with the Molluscoida.

Of the Mollusca which swarmed in the Postcambrian seas, but few had then been developed or at least have been registered: less than 10 per cent of the whole fauna, and but 3 per cent of these are of the dependent type of the oyster 
and clam. The rest are free (gastropods 39, pteropods 32 species). The sponges of the Cambrian are as yet in a large measure undescribed but the material in the collections made by Dr. Walcott from the Burgess shale indicates the great abundance of the silicious sponges, while they retain a simplicity of form which is in contrast to the progressed species of the Devonian.

With the foregoing we may contrast the great outstanding army of independents-the Crustacea. Of the trilobites there are 502 species and of the Eucrustacea, the primitive shrimps, 89 species-together constituting one-half the entire list of described species of the fauna. These creatures were all elaborately innervated and highly locomotive throughout their entire life, and their anatomical and functional structure was a very advanced attainment in specialization. Such an enormous development of the single type of structure represented by the trilobites, which were here at the climax of their entire career on earth, gave material and opportunity for different degrees of progress, delay, decline and reversion, all of which are to be estimated in the construction of a true classification of the great group. No adequate conception of their specialization can be obtained without a study of the restorations of their ventral anatomy as shown by Neolenus, a late member of this Cambrian or "first fauna." This has been restored by C. D. Walcott on the basis of specimens collected by him in the Middle Cambrian of Burgess Pass, Alberta. The trilobite has maintained throughout its individual (ontogenic) and race (phylogenic) existence, complete freedom and full locomotor efficiency. And if this is true of them it is $a$ fortiori true of the Eucrustacea ${ }^{1}$ of this fauna of which

1 These Eucrustacea are creatures which to the casual observer show evident relationship to the "shrimps." It is interesting to a paleontologist to observe the unconscious solemnity with which biologists familiar alone with evident structures in the vast group of living arthropods or jointed invertebrates, and their classification, debate with themselves the position and affinities of these 
Walcott has brought out a most impressive number and variety.

As to the annelids or worms, speaking in broad and familiar terms, while the number of species actually recognized from the preserved parts is comparatively small, yet the rocks of this age are voluminously marked with their trails and borings, and we must conclude that these soft-bodied creatures were abundant. Deductively they must have been, for on evidence quite independent of fossil remains we look to these simply segmented creatures, or to some radicle constructed on a like pattern, as the starting point for several of the differentiated groups of the Cambrian; the specialized, partly stabilized and partly retrogressive brachiopods, the progressive crustaceans, and perhaps the echinoid holothurians and cystids. The worm radicle must therefore be very ancient and we have reason and evidence to predicate its abundance in the faunas of Precambrian time.

Here then, in essence, we have the significance of the Cambrian fauna in terms of its abundance and independence, retreat and advance. It enters later geologic stages of existence equipped to carry forward its great dependent groups to further expansion within the restraints of its induced limitations and a specialization into more perfected adjustments but without hope of any advance that will improve the grade of life; and to direct its independent groups, its segmented annelids, trilobites and crustaceans upward with the promise of quick developments which are

ancient creatures to those now living and their proper place in the scheme of living things; forgetting or overlooking the fact that these designs are unreckoned millions of years old and are in truth the parents of all such conjectures. They antedate classifications and the objects classified. Governor William Bradford, of the Plymouth colony, must have at least ten thousand living descendants in this land of ours, rejoicing under various patronymics which time and marriage have brought. To which does the old progenitor now belong, Smith, Jones or Robinson? All alike may claim him. 
to advance without restraint into higher but more transitory organisms.

\section{THE CAMBRIAN FAUNA GENERALLY}

The known Cambrian fauna of North America is representative of the total life of that age, as its lists are twice the size of all from the rest of the world. The additional species from Europe, Asia, Australia and South America, in which the proportions of immobile and mobile organisms are about as indicated above, make a sum total of approximately 1500 species. In this total the trilobites and other crustaceans constitute 58 per cent; for the North American fauna these latter figures are 58.7 per cent. But it is obvious that this fauna was an essentially independent congeries of animals in which we must reckon all the crustaceans, all the thin-shelled hyaline pteropods, all the annelids, practically all the thin phosphatic and allied brachiopods (in contrast to their descendents) and perhaps the limpetlike gastropods-a fully 90 per cent representation of locomotive freedom. It is an assemblage, too, which, so far as our knowledge extends, was essentially free of expressions of symbiosis, even of the most innocent form.

\section{PRECAMBRIAN LIFE (ARCHEOZOIC)}

Here lies the field still of greatest importance for future investigations of the beginnings of life. Out of it, thus far, little else than suggestions have been derived as to the actual living things of those vast ages. From the midst of its heaved and altered sediments have been rescued here and there a few tangible fragments of recognizable species of life. From the critical knowledge which is to help most in the unveiling of the progress of life, this difficult repository is of such high importance that it should enlist the concern of students who are well endowed with patient en- 
thusiasm, for no service to this science, whether in fact or philosophy, is more competent or more needed than the evidence which lies here buried. To Walcott, who has lifted the veil from the unsuspected specialization of the Cambrian fauna and, with Barrande, has taught us to regard that fauna, not as primitive but a venerable monument of life, we owe our best knowledge of life in the still earlier ages.

Out of the vast Precambrian ages and its great seas which, in view of the high specialization of the rich Cambrian fauna, must have laid down fossiliferous sediments for inconceivable ages, we know immense growths of lime deposits built up as reefs in the seas like the corals of today and in whose formation algal life seems to have played effective part. There has also been described a spongelike skeleton called Atikokamnia (A. lawsoni and A. irregularis Walcott) from the Steeprock series of Ontario, an organism so primitive in its skeletal characters that its reference even to the sponges lies in doubt. ${ }^{1}$

Walcott' has described as "Micrococcus sp. indet.," a bacterium from the Algonkian (Precambrian) of Gallatin county, Montana, which the bacteriologist Kligler ${ }^{3}$ regards as close to the existing Nitrosococcus which derives its nitrogen from ammonium salts. "The cell structure of the Algonkian and of the recent Nitrosococcus bacteria is very primitive and uniform in appearance, the protoplasm being naked or unprotected." With this point before us we are confronted by the impressive inference that this simplest of organic structures has defied change and the ages. The type at least has not failed to find its appropriate surroundings or to adjust itself readily to change in them. It is the

1 It appears from the comments of Walcott that we must not yet regard the horizon of this organism finally established, though Van Hise, Leith and the discoverer, Lawson, regard it as from true sediments of the Precambrian $\mathrm{Hu}$ ronian.

2 Proc. National Academy of Sciences, v. 1, p. 256, 1915.

3 See Osborn's "Origin and Evolution of Life,"' 1917, p. 85. 
true example of the deathless life wherein reproduction by division has carried the parent into all its uncountable progeny.

Once more it is well to enforce the fact that the simplest organisms have lived the longest and those that have so lived have been subjected to the minimum of change and the optimum of adaptation. While we recognize that to this the sessile condition and immobility arising from any other cause contribute, it is such persistent simple forms that Ruedemann has called "immortal types."

\section{THE COMPOSITION OF THE LOWER CAMBRIAN FAUNA IN NORTH AMERICA}

This is the "first fauna." The casual remnants of life that have been found in the Precambrian rocks cannot be characterized as fauna or flora. And this "first fauna," so far as known to us, must be regarded as an escape from unfavorable conditions, for its sediments have everywhere been easily liable to alteration by earth movements and destruction of its organic contents. So it is fair to say that much of the fauna is still to be uncovered. In its known composition, however, which is now numerically estimated at 243 species in North America, there is essentially the same relative prominence of groups of organisms as in the total Cambrian; thus the brachiopods (76) constitute about 30 per cent, the trilobites (110) almost 50 per cent. The Mollusca are represented chiefly by the gastropods (16 species), mostly of the simple, conical, limpet shapes and the free-swimming pteropods (12 species). Otherwise there are representatives of algae (2), sponges (1), corals (8), annelids (trails; soft bodies not retained), cystids (elementary echinoids) (2), pelecypods or clams (1), eucrustaceans or shrimps (5). That the percentage of locomotive

1 Op. cit., p. 116. 
independence here indicated is essentially that of the Cambrian fauna as a whole is an indication of how slowly subjection and dependence permeated the life of the earth.

\section{THE BEGINNINGS OF SYMBIOSIS AND PARASITISM}

In the foregoing we have endeavored to indicate that dependence is not a primitive but a secondary condition of organisms; that, as the alternate state to independence, it had involved in lesser degree even so early a fauna as the Cambrian; and in successive faunas to the present we have the full knowledge that it has vastly increased in its scope and effect. We have no reason to believe that the dependent habit of life once acquired has ever been fully removed or lost; it is safe to say that dependence, under the normal procedure of the organic law, is incurable; an adaptation without escape.

We are now to consider, not the expressions of race dependence, but those consociations among early animals which have led from conditions of mutual support and interdependence (symbiosis) into conditions of parasitism or absolute dependence of one animal or plant upon another's vital functions. From the protozoa and bacteria to man and the oak, nature is riddled with such expressions of dependence and surrender.

In the more innocent expressions of symbiosis termed mutualism and commensalism, where associations of organisms are purely social and apparently harmless or even mutually advantageous to the participants, it is probable that once fixed the outcome is infallibly deleterious.

The glass-rope sponge (Hyalonema) has its coil of rope by which it anchors itself to the sea bottom, incrusted and shielded by a coral (Palythoa), which spreads like a thin wrap of felt all about it, while its ally the Venus's Flower- 
basket (Euplectella) imprisons a crab in its interior behind the bars it throws across its aperture but feeds it with ever changing water currents; worms and anthozoan corals grow together, with the tubes of the former surrounded by the cells of the latter, both sweeping the water currents for food which may go to either mouth; dead snail shells in which hermit crabs have taken residence are often beset with sea anemones (Sagartia and Adamsia) whose stinging cells may scare away the enemies of the crab, while the crab favors the fixed anemones by moving his establishment from place to place, thus to new feeding grounds.

All these conditions seem on the surface entirely harmless or positively advantageous to all parties involved; that is, advantageous in the sense that they make life easier, less arduous, discourage activity and perfect adaptation.

The general effect of all symbiotic conditions is degenerative. They themselves arise from degenerate tendencies and could not exist save that degeneration had already set in. They are expressions of this condition and serve to confirm and transmit this tendency. The fact is tremendously evident that even the most innocent of symbiotic, dependent or attached conditions of growth is the leaven of progressive degeneracy.

It is well known that the critical methods of morphology and embryology have been requisite to determine the original ancestral independence of the most debased of parasites. While the doctors of the Middle Ages wondered over the barnacles and pictured them as growing on trees, dropping thence to the ground transformed into geese, their real nature as debased crustaceans was not unfolded till the life history of the creatures showed that their early stages were free and predatory, and the adult condition one of extreme adaptation by progressive loss of functions and organs. Thus the parasitic and dependent habit is, in metazoan life, preceded by a free and predatory condition. 
Once the dependent habit is established the capacity for reaction grows weaker; degenerative adaptation creeps still further back in the life of successive generations and the degradation of the adult state becomes more profound.

\section{Complex Character of Parasitism}

Symbiotic conditions reckoned in terms of the host are often helpful. There is a world full of benign parasites but they are not haphazard.

True parasitism as known amongst the existing animals and plants is in most cases exceedingly complicated. Moreover, when the infesting parasite requires a series of hosts, a different one for each phase of its development, and when in all its stages it is a soft-bodied creature, we must recognize the hopelessness of trying to unravel from the geologic record the history of such complex adjustments and be satisfied to take them as they are after human ingenuity has succeeded in deciphering them. The course of such perfected adjustments in evil living may be interesting knowledge, but the cause and origin of them can be deciphered only by the mode which we are following through the historic study of the more legible expressions of these associations: And it is altogether probable that such complicated careers, especially such as are best known because of their relation to man, are of quite recent adaptations.

\section{Beginnings of Symbiosis}

Our analysis of the Cambrian fauna has shown the degree to which it has been affected by dependence. So far, however, as our present acquaintance goes, there is no obvious record of symbiotic or commensal conditions in that fauna; if they occurred at all, they were conditions rarely recorded. This is a significant fact in its bearing on the origi- 
nal directness and independence of life and must be given important weight in the conclusion that life started unperturbed and with the best upward purpose; and even if the evidence is essentially negative it loses no force from this fact.

It would seem then that not until life had got in full swing did these organic combinations come into existence, even in their simplest commensal expressions. Regarding bacteria and sporozoa we have written on a later page, but among the invertebrates even the consociation of the annelids and the corals, which formed easily and early and has endured long under manifestations of various sorts, does not seem to have yet appeared with the opening of Ordovician time.

\section{Relation of Srmbiosis to Parasitism}

We have intimated, and it seems a natural presumption, that parasitism, by which is meant an adaptation in which one organism has become helplessly dependent on another for its existence, is the outcome of the innocent combinations of symbiosis. One would have little difficulty in believing that from such a complicated relation of the worms to the corals as shown in the Devonian by Pleurodictyum and its associates, which we shall presently describe, a condition of genuine parasitic dependence might well have resulted, even though the fact is not actually demonstrated. It would seem that we must continue to distinguish an innocent symbiosis from a dependent symbiosis or parasitism, but this is based only on our present understanding, and a statement that the latter can be independent of the former and not a consequence upon it seems so illogical that it is really not likely to stand up when the facts are more far-reaching. In parasitic symbiosis the host is the resisting, not the consenting or coöperating partner. 


\section{ILLUSTRATIONS OF PRIMITIVE PARASITISM}

\section{The Case of the Annelids}

One group of animals, the worms or annelids, is of prime interest in these considerations. The worms occur in vast variety in the existing fauna and their derived or secondary expressions are abundant. It is not with these that we are concerned. The primitive or archetypal worm is conceived as a simple fore-and-aft segmented structure in which the innervation is repetitive by segments and the alimentary and distributive organs simple and continuous. The worm has led a long career of ideal independence and it has been the architectural model for the higher creation. In the judgment of many morphologists there is, as we have already intimated, a convergence backward into the past toward the archetypal worm, of great differentiated stocks like the brachiopods and the echinoids, while we recognize in all segmented creatures the normal continuous progeny of the annelid prototype.

Worms, we may restate, were common enough in the Cambrian fauna, known both by their trails and burrows and by some highly specialized bodies; and it is probable that such evidences of their existence will not long be lacking in the Precambrian. The worm, however, had a soft body; its acquisition of a cover or shell which would enable its preservation was a secondary development. So we are confronted in all the early rocks by few actually fossilized worms but with a great abundance of their trails in the soft muds. The worm buried itself halfway or wholly in the mud; encased itself, at times, in tubes of its own making; thus ensuring a protection against adversaries. But it retained an active, vibratile vitalism and an entire freedom from attachment to its tube. The rocks of these formations are often filled with vertical worm tubes, and the surface of the same beds may be marked by fes- 
tooned and wavy markings in the sand, made by the occupants of these tubes as they swept the sea bottom with their extended bodies. They were eager commensals and in the Paleozoic faunas we find them in various associations, espe-

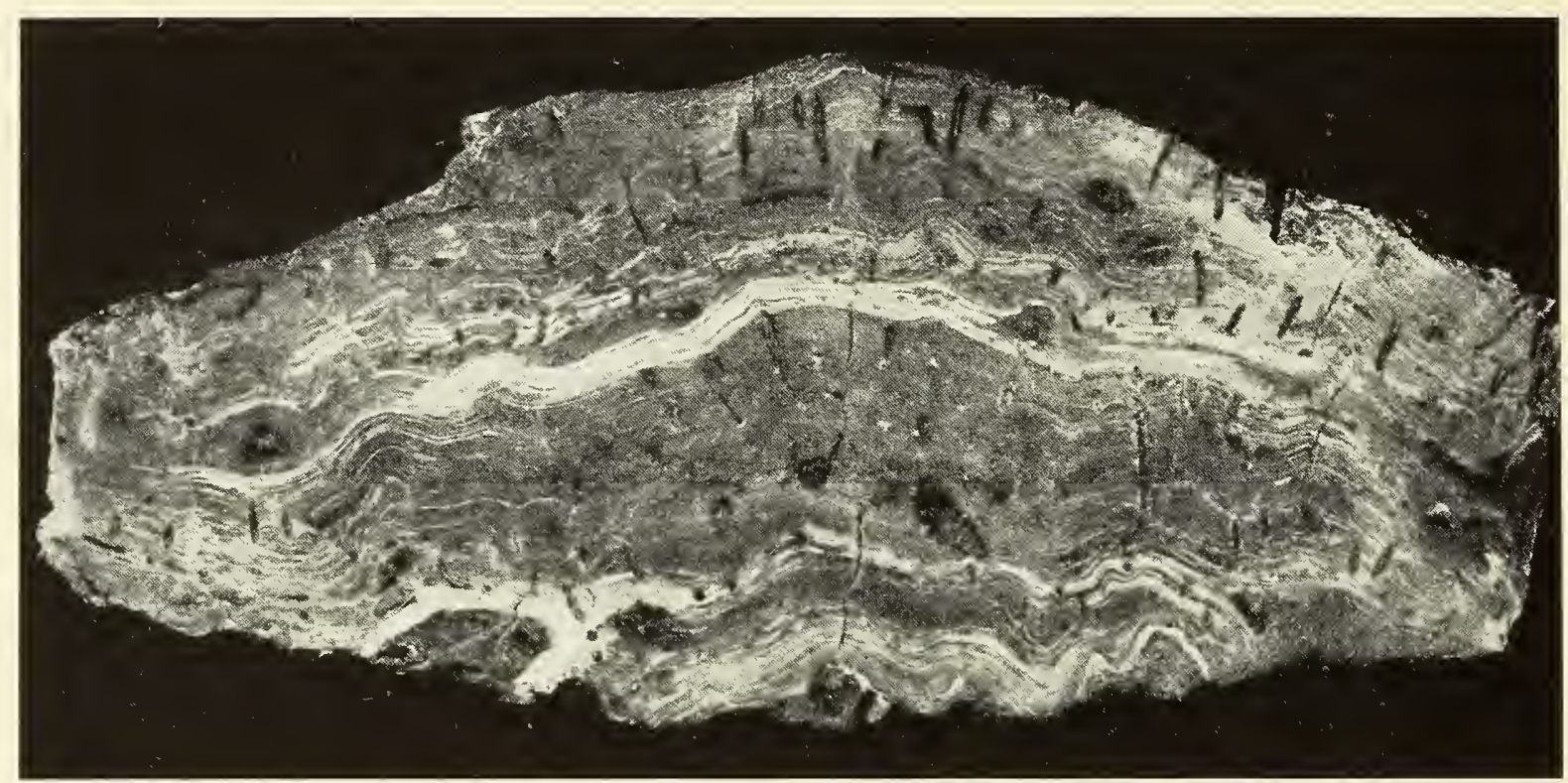

Fig. 1. Silicified mass of stromatoporoid coral full of straight wor'm tubes (Gitonia) which start at various levels in the coral growth. Onondaga limestone (Lower Devonian).

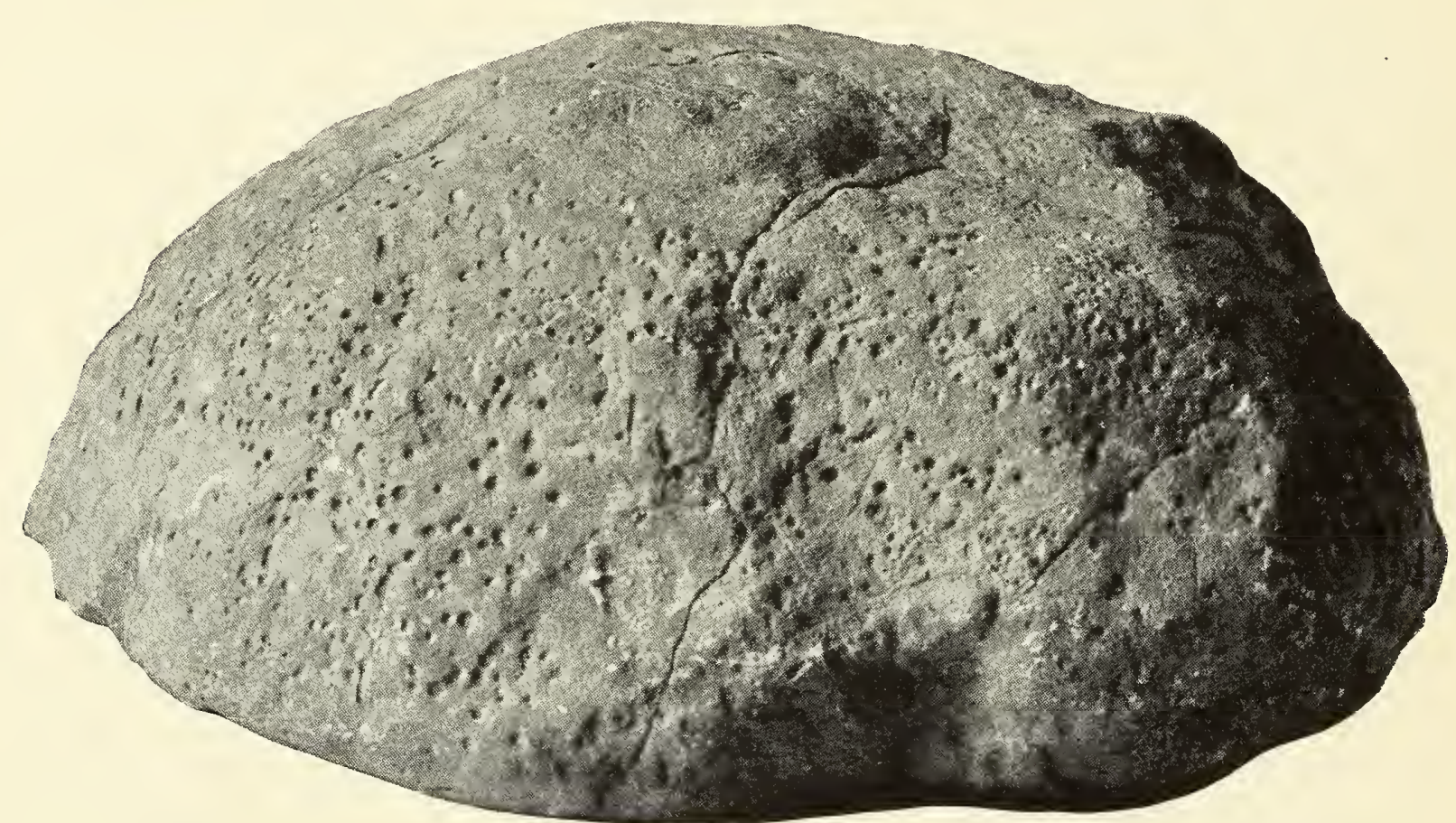

Fig. 2. A solid colony of Stromatopora constellata from the Upper Silurian (Cobleskill limestone) with its surface pitted by the openings of vertical tubes of the worm Gitonia sipho. 
cially with the corals and the sponges and the calcareous algae.

The coexistence of the tubicolous worms with the corals is one of the commonest phenomena of present seas and it became established as early as the Silurian. In most of the ancient cases observed it is an elementary expression of commensalism, but not long after its start it becomes at times rather complex. Worm and coral may start together directly on settling down from the free larval state, or conjunction may be formed by attachment of the annelid larva after the growth of the coral has well progressed. In both cases the growth of the latter engulfs the former save at its tentacled aperture. We give herewith examples of these occurrences. ${ }^{1}$

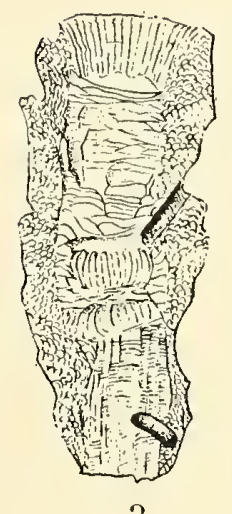

3

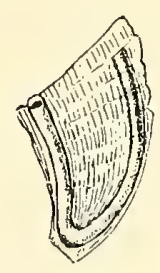

5

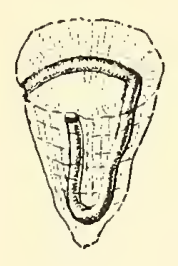

6

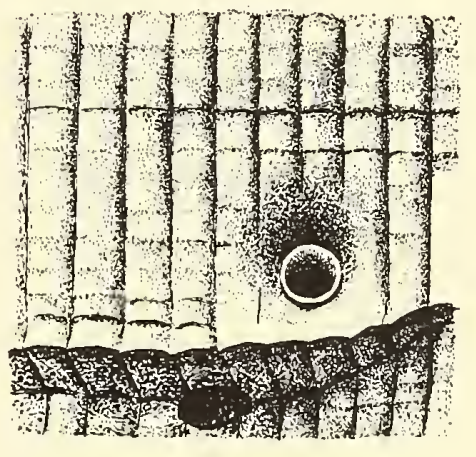

7

Fig. 3. The coral Cystiphyllum with short tubes of Gitonia corallophila opening outward through the thecal walls.

Fig. 4. A calyx of Zaphrentis with a number of tube openings of Gitonia.

Figs. 5, 6. A Zaphrentis from two points of view to show the course of the tube of $G$. corallophila with both ends opening outward into the calyx.

Fig. 7. Tubes of this eharacter opening through the lateral walls of Zaphrentis. All are from the Onondaga limestone (Lower Devonian).

1 Some of these illustrations are taken from the writer's "Beginnings of Dependent Life"' (1908), but to these and to the other classes discussed, new illustrations have been added. 
Silurian. The reef-building coralloids, Stromatopora, which abound in the stages of the Silurian are frequently permeated with straight tubes of the worm Gitonia sipho. This is an occurrence often repeated in the Stromatoporas and true corals (Favosites) of the Lower Devonian.

Devonian. Interesting simple combinations of this category are shown by individual polyps of cyathophylloid corals like Zaphrentis and Cyathophyllum, where we have frequent indication that the tube of the worm is open at both ends and its continuity unbroken, each end opening at the tentacular surface of the coral. Often the worm dies in the coral and is buried in the stereom, or its upward growth is not so rapid as that of the coral and it is left behind with its head protruding from the side of the corallite. It is also quite evident that the coral may so build its tissue about the worm as to inclose it in a sheath which takes the
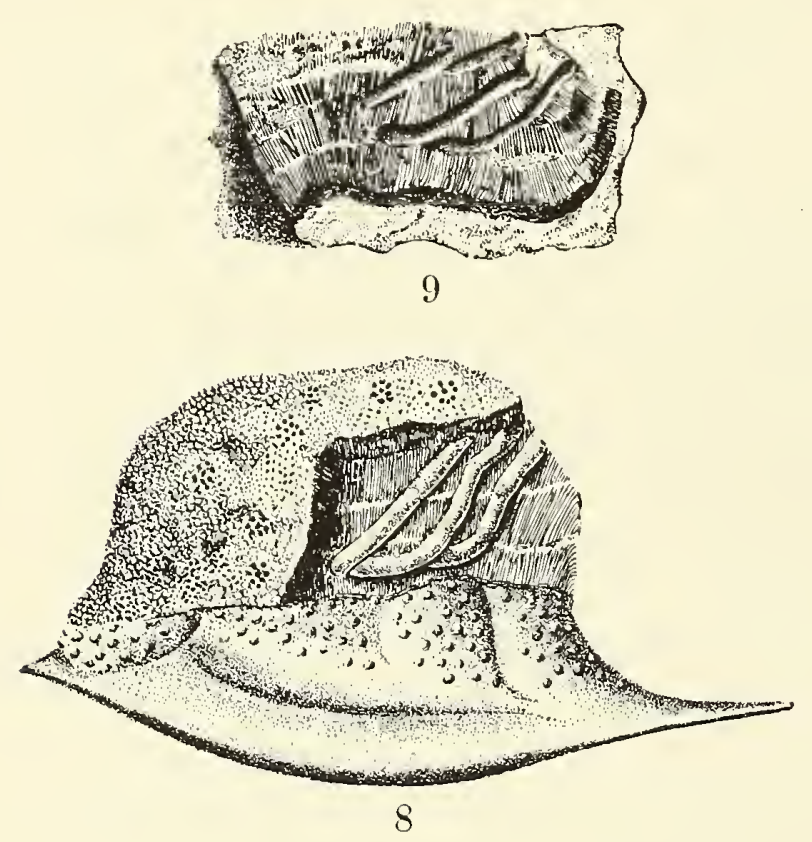

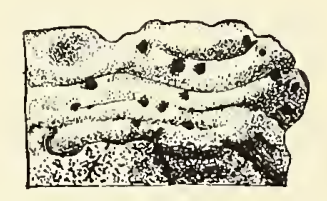

10

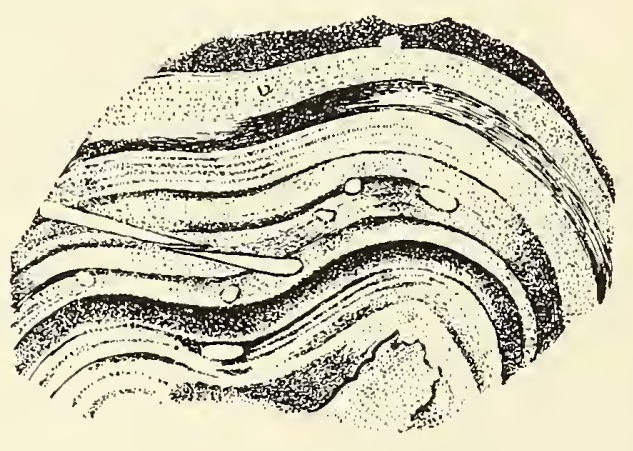

11

Fig. 8. Head of the trilobite Dalmanites overgrown by a colony of the bryozoan Monticulipora in which is embedded a series of the tubes Gitonia sipho. Onondaga limestone (Lower Devonian).

Fig. 9. Colony of the coral Favosites sphaericus with a series of Gitonia tubes. Helderbergian (Lower Devonian).

Figs. 10, 11. A weathered surface and a transverse section of a Stromatopora full of Gitonia tubes. Cobleskill (Upper Silurian). 
place and serves the purpose of a self-constructed tube. Thus the worm Gitonia corallophila expresses itself in various meanderings among the simple corals. Some small lens-shaped coral colonies from the Ordovician of Iowa are permeated with worm associates, all of which seem to start from the initial basal point of growth of the coral, and then, after a single turn or so of the tube in Serpula fashion, strike outward radially between the polyp cells, all reaching the tentacle surface of the colony. This combination indicates that the embryo worms aggregated themselves in numbers about the anchoring coral larva.

Spiral worms and corals. These interesting associations are common throughout the Silurian and Devonian. Spiral worm tubes passing in these faunas under the name of Spirorbis and living independently are normally, or at least often, attached to shells of brachiopods and mollusks, where they escape any chance of becoming embedded, and after a few initiatory attached coils the tube often becomes free and resolves itself into very loose spirals (see figures of $S$. angulatus). In the tube called Autodetus, which is frequent in the Devonian, there is an initial spiral attachment, but the whorls of the free tube keep in contact and

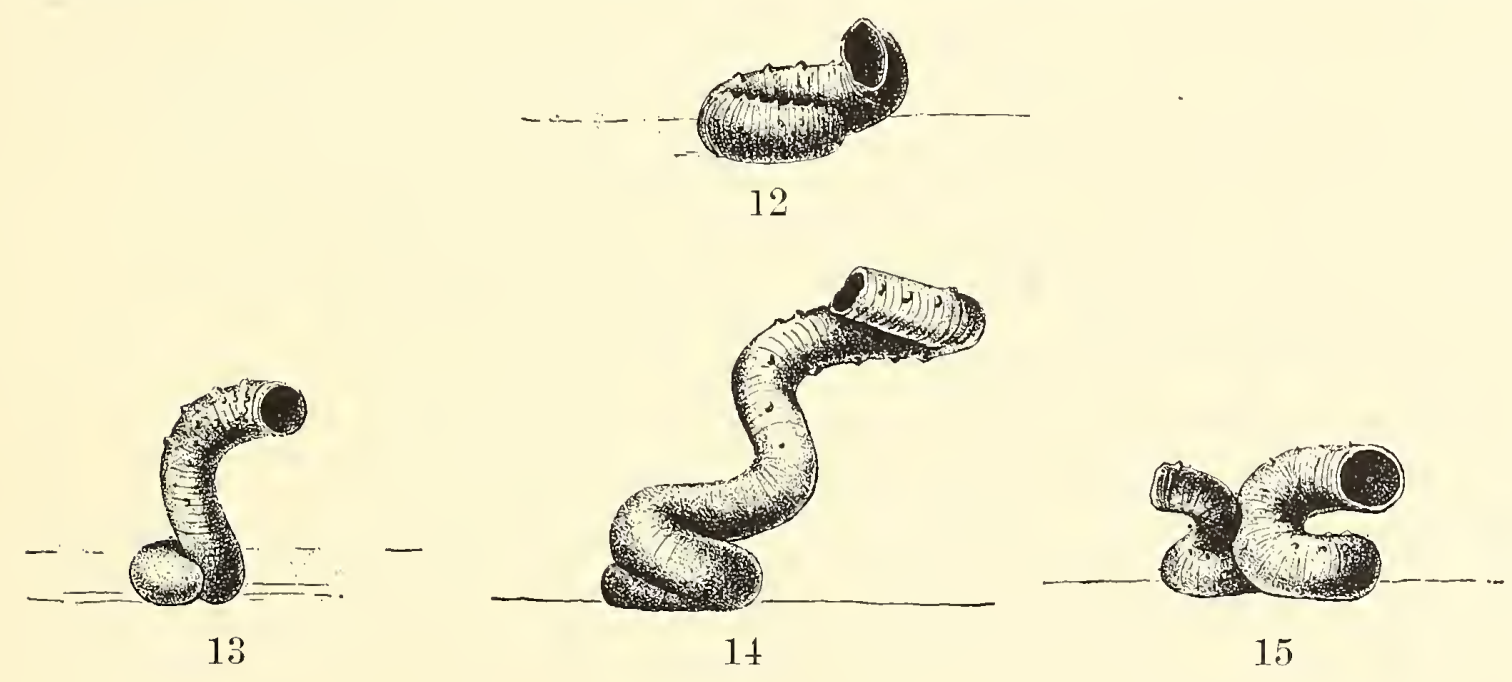

Figs. 12-15. Enlarged drawings of Spirorbis angulatus, a worm tube from the Hamilton group (Middle Devonian). These show the tendency of the tube to unwind in a lax spiral as soon as fixation is firmly established. 
the whole shell takes on the form of a smooth cone attached by its apex. It is to be understood that the worm in these cemented tubes was highly flexible and vibratile and free to extend itself from the aperture and was not attached to the tube shell; and indeed, if like many living worms, could

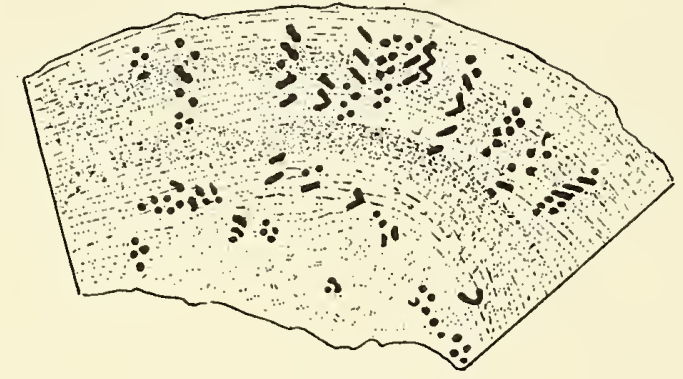

16

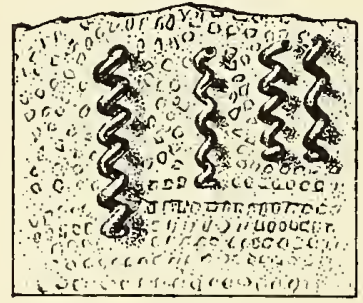

17

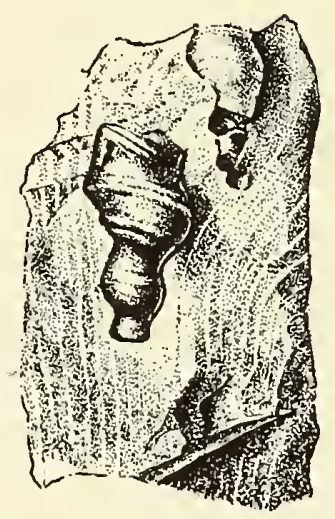

18

Fig. 16. Section of a Stromatopora colony showing the eut ends of the spiral worm tubes Strepindytes concoenatus from the Cobleskill limestone (Upper Silurian). The apparent difference in direction of volution in these is entirely due to difference of direction and angle at which the tubes are cut.

Fig. 17. An enlarged restoration of the character of the worm tubes.

Fig. 18. Streptindytes acervulariae Calvin. Two tubes of this spiral worm in a colony of Acervularia Daridsoni. Middle Devonian, Iowa.

abandon its shell entirely and build a new one somewhere else. Streptindytes concoenatus is such a worm, with tube stretched out in loose spiral, which we find to be common in the Stromatopora colonies of the Upper Silurian (Cobleskill) limestones. Our figures 16, 19, indicate that these worms started their growth at different stages in the growth of the colony, obviously attaching themselves to the 
outer surface of the coral when it was well grown, but it is interesting to see that at any given stage they attach themselves not singly but in numbers, as though each settlement indicated a new crop of young worms. Streptindytes acervulariae Calvin is a quite large spiral tube not uncommon in Acervularia davidsoni, a coral of the Middle Devonian of Iowa, and S. compactus, a short, close-coiled species which is found buried up in the calcareous substance of the Iowa Middle Devonian Stromatoporas. These embedded worms were often eventually strangled by the more rapid overgrowth of the coral, as there was no lateral way out for their heads as in the straight tubes.
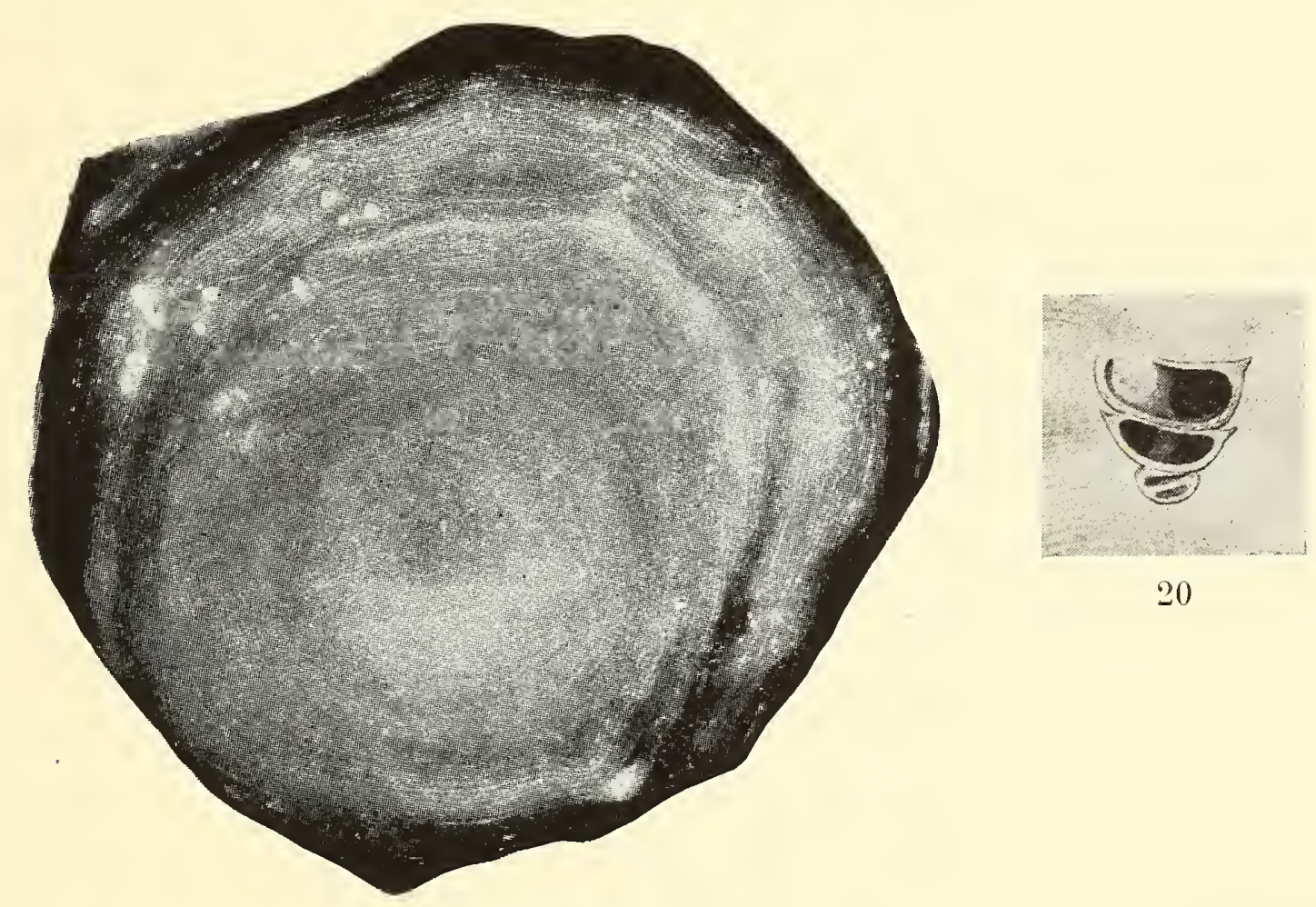

20

19

Fig. 19. Streptindytes compactus, a spiral worm embedded in a solid stromatoporoid coral. Sections of the tubes are indicated by the white dots.

Fig. 20. A single individual enlarged. From the Middle Devonian of Iowa.

The extraordinary case of the coral Pleurodictyum and its commensals. Pleurodictyum is a small compound coral growing in lens-shaped colonies with large cells, in its structure very similar to the common honeycomb coral Favo- 
sites but distinguished by its habit of growth as well as details of cell structure. It does not abound in species and all that are known belong to the Middle and Lower Devonian faunas. The following are its known species:

P. lenticulare Hall; Helderbergian (New York).

P. lenticulare var. laurentinum Clarke; Grande Grève limestone (Gaspé).

P. convexum Hall; Onondaga limestone (New York).

P. problematicum Goldfuss; Coblentzian (Western Europe). Devonian.

P. constantinopolitanum d'Archiac and Verneuil; Roumeli shales1 ('Turkey).

P. amazonicum Clarke; Maecuru sandstone (Brazil).

P. styloporum Eaton-Hamilton (New York, etc.); Middle Devonian.

The combination of the Pleurodictyum with what was long called a "coiled central body" or a "wormlike object," actually the curved tube of a commensal worm, has long been known from the internal casts preserved in the sandy shales of the Coblentzian.

The concurrence of the coral and its convoluted worm has been noted in several of the species here mentioned, but the varying degree of its frequency is instructive. Thus in the earliest species, $P$. lenticulare, I have seen the worm tube very rarely, after the examination of a considerable number of examples; in the var. laurentinum not at all; never in the large species $P$. convexum Hall of the Onondaga limestone. The single published illustrations of $P$. amazonicum and $P$. constantinopolitanum show its presence but enable one to form no conception of its prevalence. The combination is frequent enough in $P$. problematicum to have given rise to the specific name of the coral. The American Middle Devonian P. styloporum has afforded the material for most of the illustrations here given. Of this very common species in the calcareous shales of the Hamilton group I have been able to examine critically a great many individ-

1 The Roumeli shales of Roumeli-Hissar and elsewhere in the vicinity of Constantinople are generally regarded as the Mediterranean equivalent of the Coblentzian of the Rhineland. 
uals and it is safe to say that the worm is present in the majority of examples. It is usually easy to determine its presence on inspection of the tentacular surface of the coral by the contrast between its round tubes and the angular coral cells. All the specimens here figured to show the convolutions of the worm have been drawn from actual preparations.

The history of the combination in $P$. styloporum is as follows: At the close of the free-swimming larval stage the coral, in fully eight cases out of ten, selected and attached itself to a dead or living shell of the common gastropod Loxonema hamiltoniae. ${ }^{1}$ Directly upon fixation or even actually contemporaneous with it was the attachment of the larval worm upon the gastropod and alongside the incipi-

1 The selective attachment of such lens-shaped coralloid stocks seems to have acquired directiveness with the progress of time. At any rate we have a suggestive intimation of this in the very common Chaetetes lycoperdon (Prasopora simulatrix) in the Trenton limestone of the Ordovician, which is a stony coral

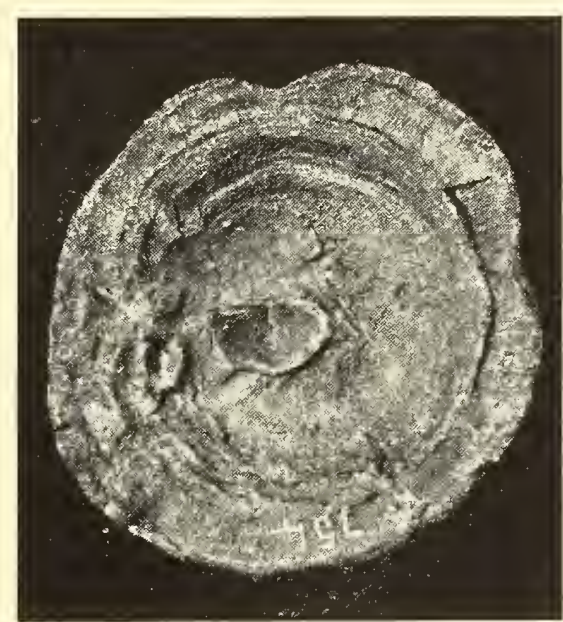

Fig. 21. Basal surface of the solid bryozoan colony, Prasopora selwyni, which has attached itself to the brachiopod Plectambonites. Trenton limestone (Ordovician), Ottawa.

of quite the same shape and habit of growth as these Pleurodictya. This is found attached sometimes to brachiopod (especially Plectambonites sericea) and as often to gastropod shells which were the abundant exuviae of the sea bottom. More often perhaps it is fastened to some casual stone or other hard object, but among all of which I have taken note there seems to have been no obvious preference by majority. 


\section{ILLUSTRATIONS OF PLEURODICTYUM AND ITS COMMENSAL WORM HICETES}

Figs. 22 and 23. Top and side views of the corallum in its normal size and form. The apertures of the worm tube are shown at $\mathrm{X}$.

Fig. 24. An etching which has the calcareous substance of the base of the coral removed and shows the initial convolutions of the worm tube.

Fig. 25. The under side of a corallum with the impression of the gastropod Loxonema hamiltoniae to which it was attached.

Fig. 26. The form of the entire worm tube drawn from an actual specimen.

Fig. 27. A shell of Loxonema hamiltoniae.

Fig. 28. Vertical section of a corallum, showing the convoluted worm tube.

Fig. 29. Enlarged surface of a Loxonema shell which had been the base of attachment for the coral. This specimen bears several serpulid worm tubes which were there before the coral began to grow.

Fig. 30. Section of the coral, showing tubes of more than one worm. 


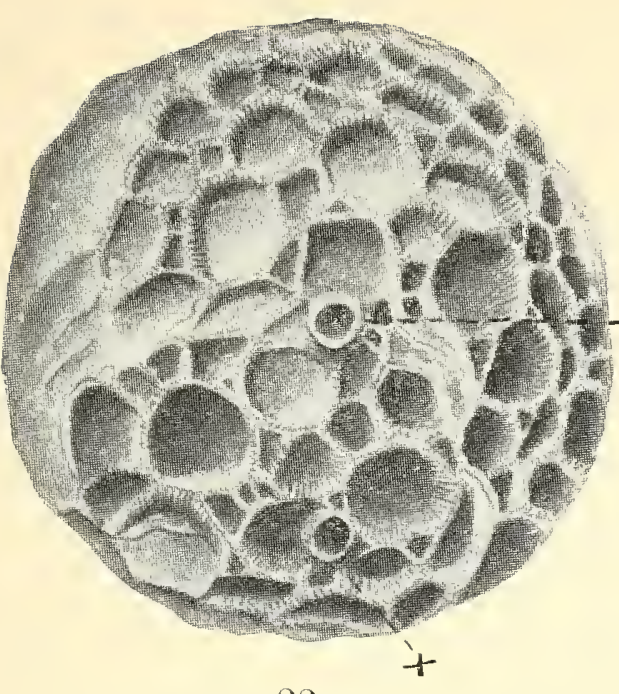

22
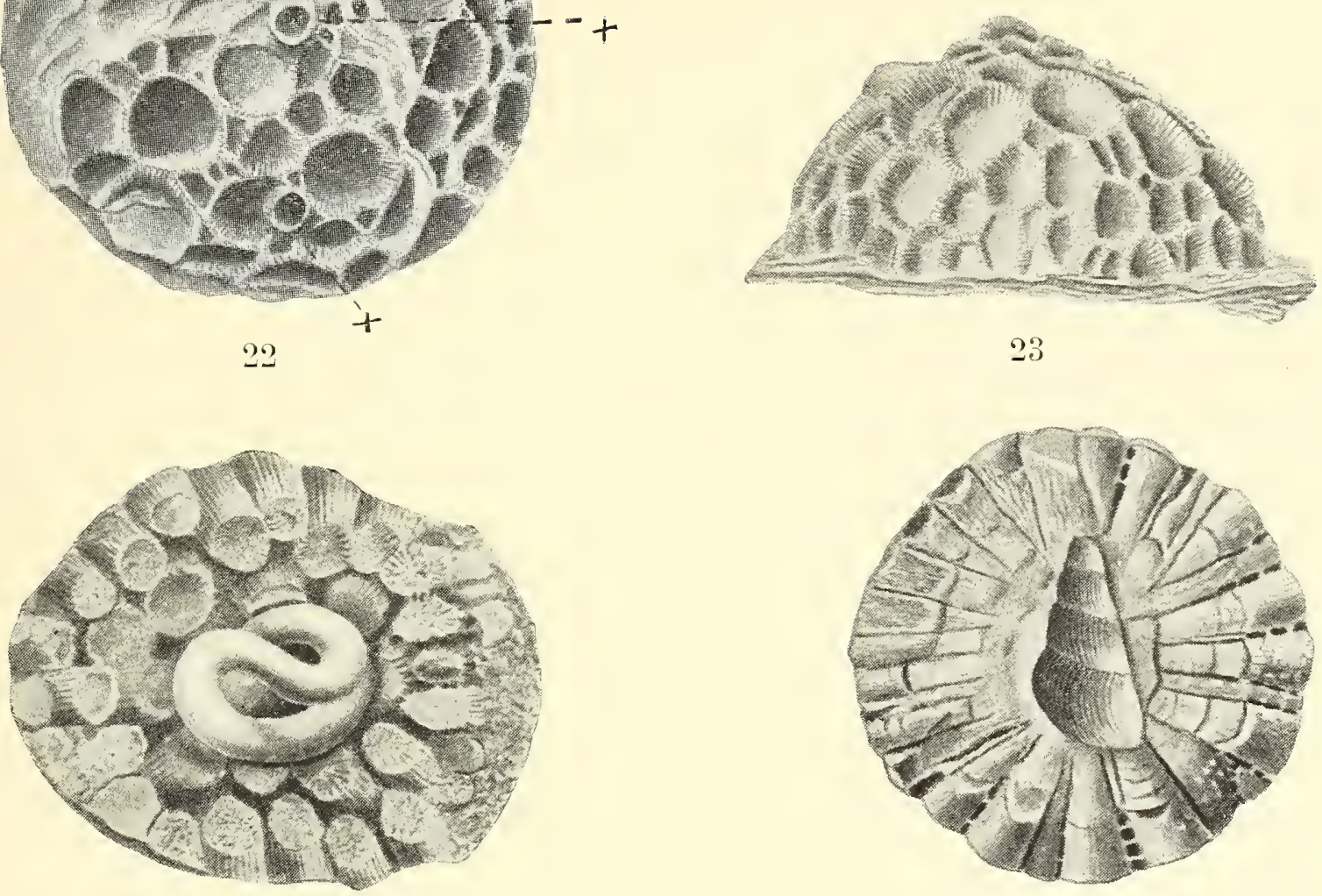

23

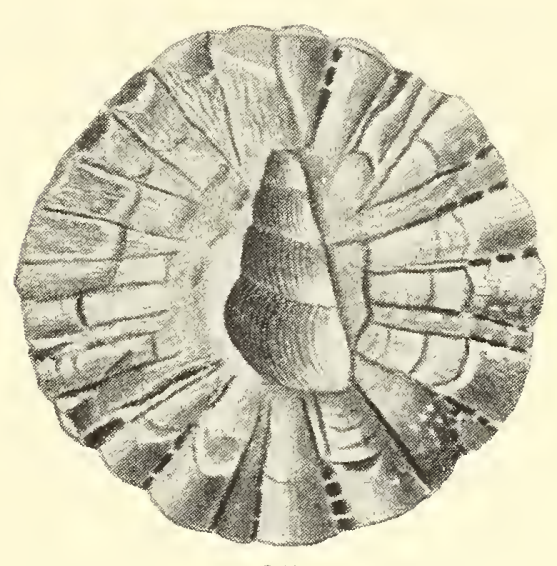

25

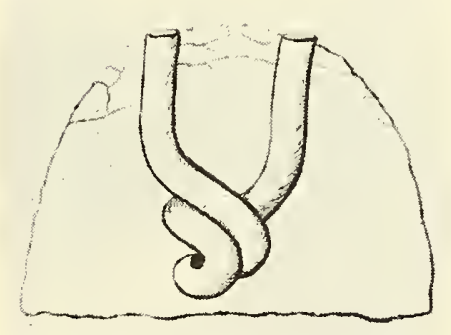

26

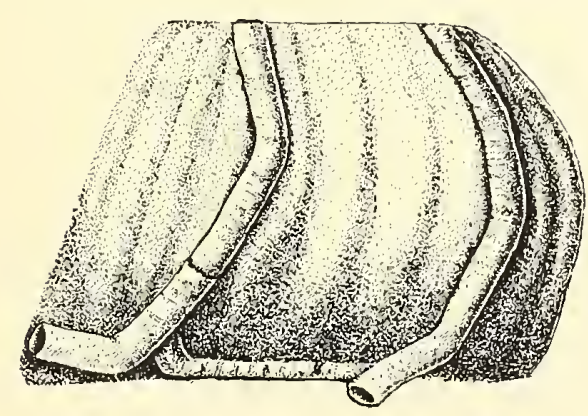

29

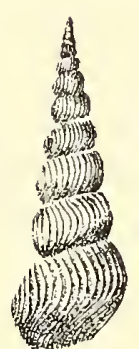

27

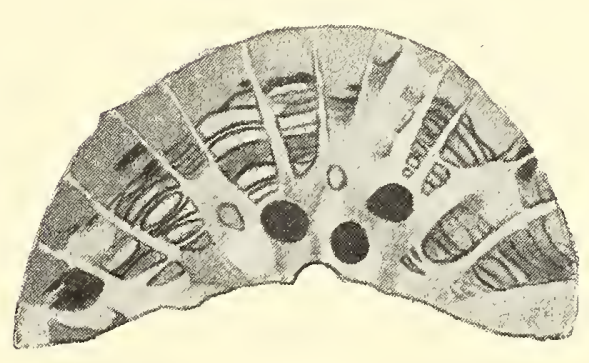

28

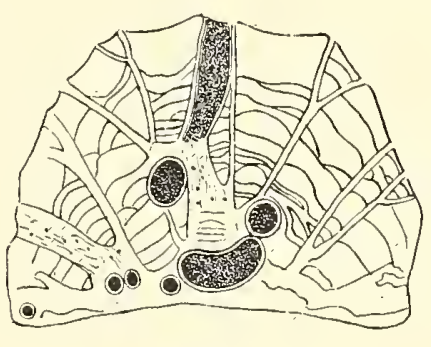

30 
Fig. 31. Etching of the basal part of the coral, showing the chief worm tube and a wormlike extension which appears to arise from the base of a polypite and turn into an upward course between the cells.

Fig. 32. The greatly enlarged interior of a dead Hicetes tube encrusted with slender serpulid worms.

Fig. 33. A minute sponge found in the tube of the large Hicetes.

Fig. 34. Chonetes sarcinulatus, the brachiopod to which the German coral Pleurodictyum problematicum usually is attached.

Fig. 35. Vertical section of coral and tubes.

Fig. 36. The base of the Pleurodictyum problematicum attached to the brachiopod Chonetes sarcimulatus. From Stadtfeld.

Fig. 37. The tube Hicetes overgrown by polyp-cells of different series.

Fig. 38. An etching of the coral showing an actual attachment of the worm tube to the snail-shell Loxonema.

Fig. 39. Vertical section of a coral showing the worm tube entrenched between the polyp-cells.

Fig. 40. An almost unique illustration of the attachment of the American Pleurodictyum to the brachiopod Chonetes coronatus. 


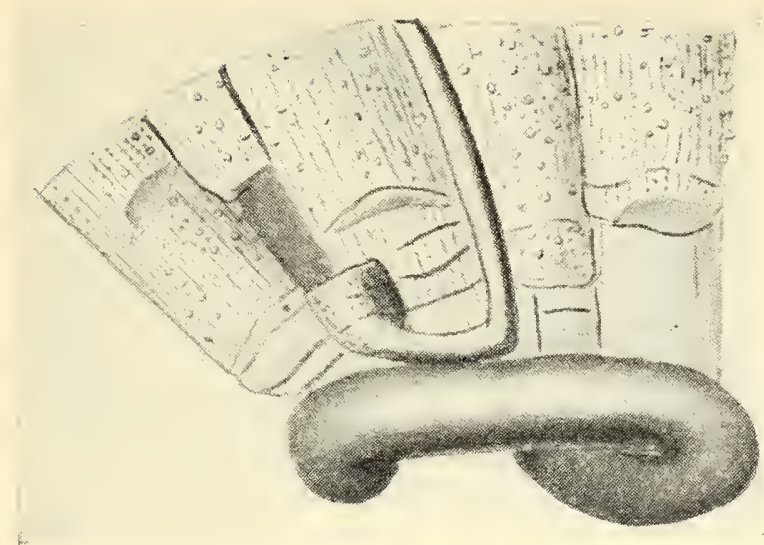

31

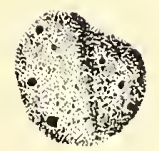

33

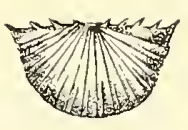

34

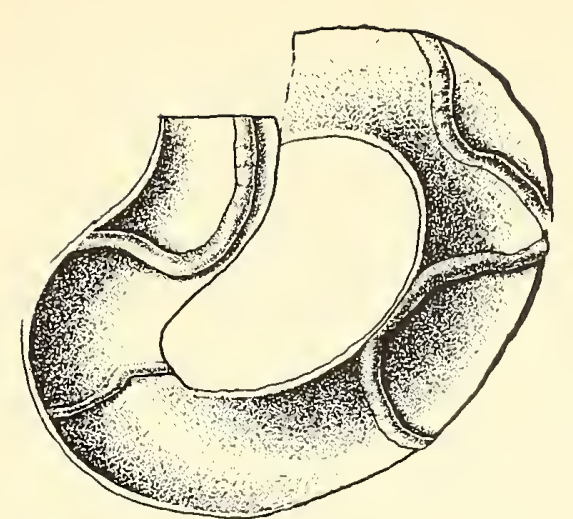

32

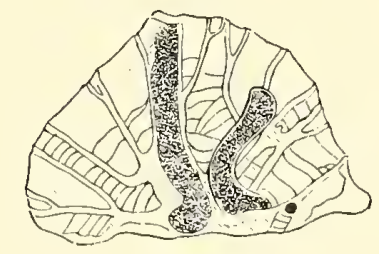

35

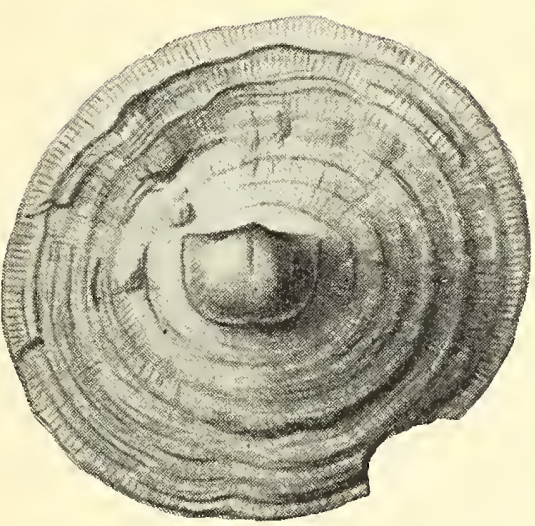

36

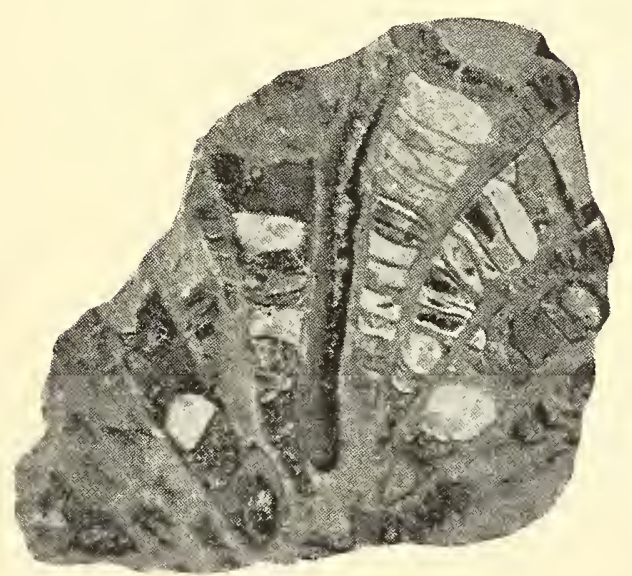

39

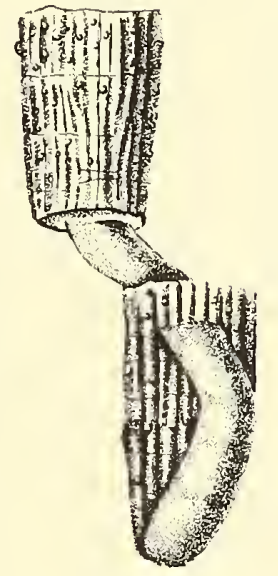

37

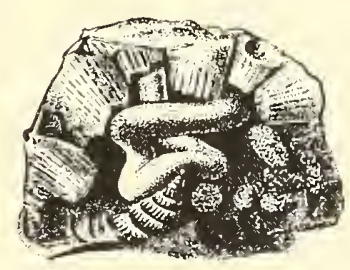

38

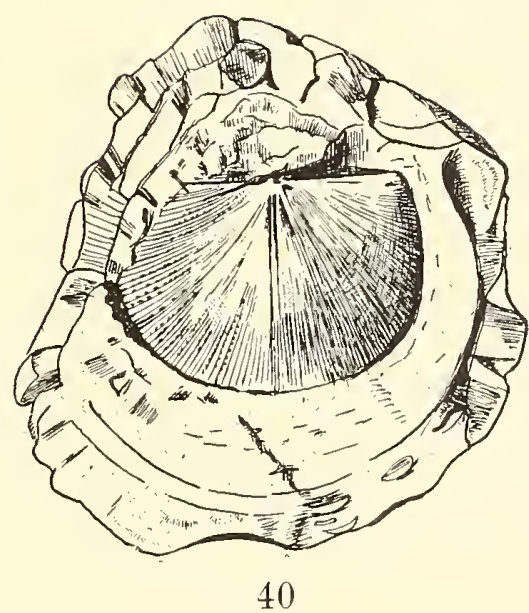


ent coral. In many cases, such as that illustrated in figure 38 , the worm tube is directly fixed to the gastropod; again it may be free of the gastropod and separated from it by the thickened basal covering or epitheca of the coral. With the multiplication of cell growth and the upward trend of the coral, the worm began its convoluted growth, its tube growing as much at one end as at the other and with the same curvature at each end. Many of the existing tubicolous as well as the boring worms have their tubes open at both ends. In view of the regularity of coiling shown in some of the commensal worm tubes it is interesting to notice that in this case the worm, after making a start, gets its double coil into parallelism for from one-half to an entire turn and then each arm starts off into a direct course outward and upward following the radial path of the coral cells. These tubes often pass in and out between the cells, shut off from them by secretions of the coral substance, keeping their extremities always at the tentacular surface, and very seldom is there evidence of the worm encroaching on the polypite cells. Still this may occur and the worm tube occasionally becomes encased by a young polypite and holds a position in the center of the cell. Not always does the growth of coral and polyp and worm go on pari passu. In a group of the largest specimens of these corallites we have seen, taken from the shales on Jaycox's run, Genesee county, N. Y., the later and accelerated growth of the polyps seems to have overwhelmed and strangled the worms whose tubes continue halfway or more upward and then abruptly end.

Other worms also may be encased in the thickening base of the growing coral, as shown in figure 30, but it is not yet clear where their apertures lie, as I have never seen more than two annelid openings at the surface of an adult coral, both belonging to the same tube. Originally opening on the tentacular surface at an early stage of coral growth, they have been buried in the later accumulations of ster- 
eom. There are long tubular passages between the corallites in early-growth stages which have not been described in the structure of this coral genus but undoubtedly belong to it. In sections these may be confounded with worm tubes, but in etched specimens, such as have here principally served for illustration, their real nature seems to be clear.

In this interesting combination there is still another member-a small silicious sponge. It has come to my notice several times. The one here figured was taken from the empty tube of the worm, but whether that is its usual position or whether it may seat itself in one of the coral calyces or whether indeed it is a usual member of the consociation cannot be regarded as clearly established. Its importance is not to be magnified; such little organisms are easily entangled in growing corals and must be expected in the fossil state.

Some illustrations are here given which show how readily the dead parts of these organisms become encrusted with serpulid worms. Figure 29 is the surface of a part of a dead Loxonema to which a Pleurodictyum had grown, and figure 32 shows the inside of an old tube of the commensal worm (which is known as Hicetes innexus), itself incrusted with minute worm tubes.

Interesting as is this instance of commensalism, its most extraordinary feature is the evidence of selection by the larval coral, of the body which serves as the base on which it is to grow. It is stated above that a very evident majority of the colonies of this coral Pleurodictyum, as it occurs in the Hamilton shales, are attached to an organic object and that this organic base in apparently a very large majority of the cases is a shell of Loxonema hamiltoniae. Occasionally the shell may be a Pleurotomaria of one or another species. On the other hand the Rhenish Pleurodictyum problematicum fixes itself by decided majority to the brachiopod Chonetes sarcinulatus Schlotheim. I have examined a considerable number of specimens 
of this Coblentzian species but have seen no other shell used for attachment nor have I found record of any other. Though it is not practicable to use percentages with reference to the frequency of this occurrence, the palpable fact remains that, as between these two closely allied if not identical corals, growing in different and remote basins of the sea, one selects a gastropod, the other selects a brachiopod as its base of attachment. Emphasis is put on the word "selects," for among the brilliant examples of selective adaptation none could be more striking than this. The floor of the New York Devonian sea was covered with Chonetes and of the Rhenish sea with gastropods, during the life of this coral. Were either wanting in the other fauna, hundreds of other species of organisms lined the sea bottom. It is very impressive to find the evidence of this singular Devonian association of coral and worm from parts of the world as remote from each other as New York, northern Brazil, western Europe and Constantinople. The fact that in chronology the New York occurrence is later than the rest (Lower Devonian) seems to indicate a quick spread of this adjustment over the sandy sea bottom of the early Devonian of the world, ${ }^{1}$ from which the deeper contemporary waters of New York were excepted and in which region this symbiosis did not arrive till the next succeeding stage. Of its ultimate fate a negative evidence permits us only to say that it went out with the Hamilton stage and did not return with the partial return of that fauna in central New York during the time that is reckoned as of the next succeeding stage-the Ithaca-Portage time of the Upper Devonian.

I have not attempted to escape the obvious interpretation of these phenomena nor to avoid its expression in terms of psychic function. To biologists who still find the term "instinct" a comfortable receptacle for such reac-

1 Save in the early Devonian of austral latitudes where the fauna is very unlike that of the rest of the world. 
tions, the interpretation may seem invasive. Nothing, I am disposed to believe, can be more illuminative of the progress toward and in intelligence than the early case before us, in which a directed habit has already become fixed by heredity.

Taken as a whole this combination is very complicated commensalism from a date so ancient as the Devonian, more extreme than any other yet known from the Paleozoic rocks. We find a somewhat parallel case in the present fauna described by Bouvier as occurring in the Gulf of Aden-a coral and a worm growing together, and hidden in the coral substance a gastropod on which both settled down when the partnership began; furthermore there appears to be a small bivalve in association with the worm. Other similar cases might be cited from the existing fauna.

One stands with wonder before such evidence as this from the ancient faunas, questioning how such a habitude came about, what conditions impelled, stabilized and restricted it, and our wonder is none the less because here we stand at the inception of such associations and contemplate it from a world that is full of them today. And the inquiry naturally arises: What became of this organic combination? It reached its acme only as the coral genus became old, indeed in the last of its representatives. Riddled with commensals, overloaded with boarders who fed at the same table and flourished, it may be that the worm became an effective parasite which helped to bring about the extinction of its host.

Commensalism between the worms and sponges. This combination appears in the late Devonian, but there is evidence that it is of earlier date. We have just cited the presence of a minute sponge in the Hicetes innexus, the incolant worm of Pleurodictyum, and there is an undescribed spreading sponge of the Middle Devonian (Hamilton group) which indicates the presence of coexistent annelids. The simple ancient instance I can here illustrate is that 
shown by the spiral or meandering worm tubes which are found in connection with the glass-sponges Hydnoceras and Prismodictya of the Chemung fauna (Upper Devonian of New York).

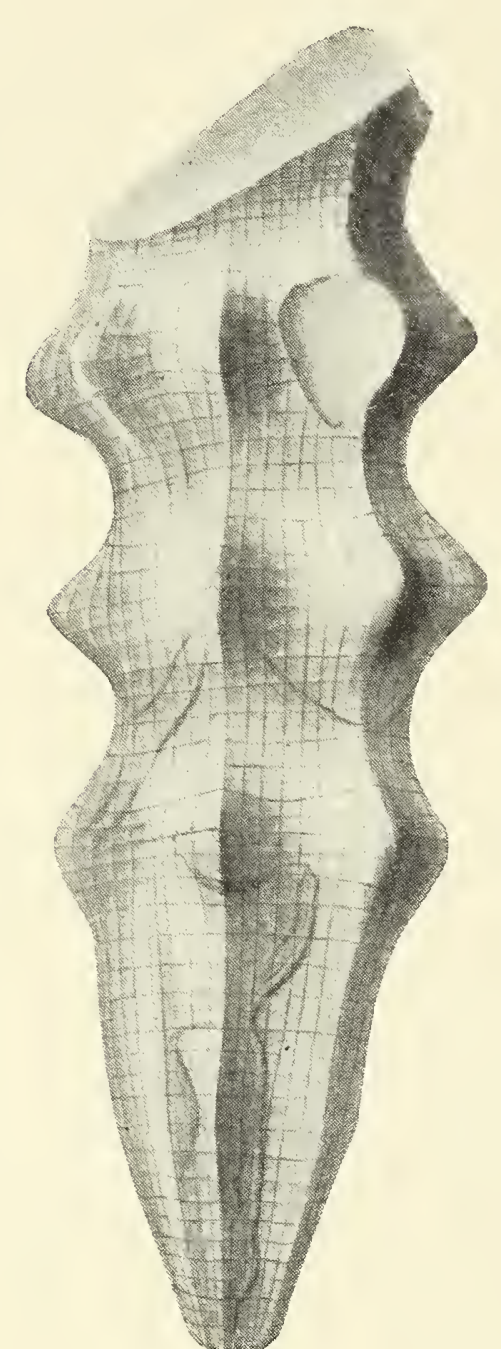

41

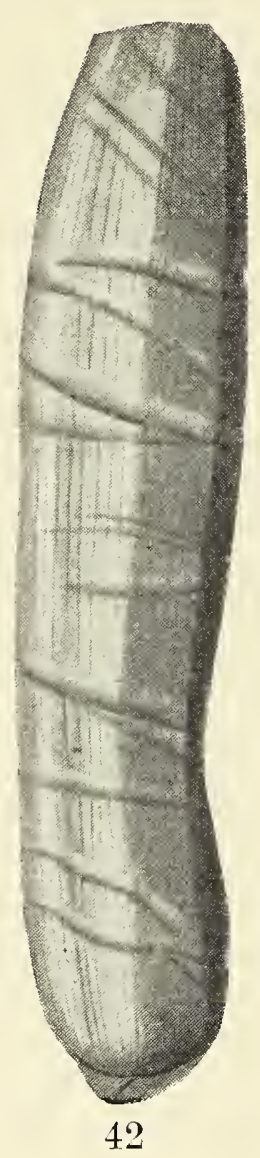

Figs. 41, 42. Two silicious sponges, Hydnoceras and Prismodictya, with markings of worm tubes on the reticulum. Upper Devonian.

In a considerable number of individuals of Prismodictya from the same locality nearly all showed the presence of the annelid commensal and as the surface of the impression left in the sands by the worm tube is in all cases crossed by the reticulated skeleton of the sponge it is inferred that the position of the former was internal. These 
are silicious sponges allied to the living Euplectella or Venus's Flower-basket, and though we find no parallel expression of commensalism in the living glass-sponges, yet Euplectella carries a parasite in the form of a crustacean which in youth enters its

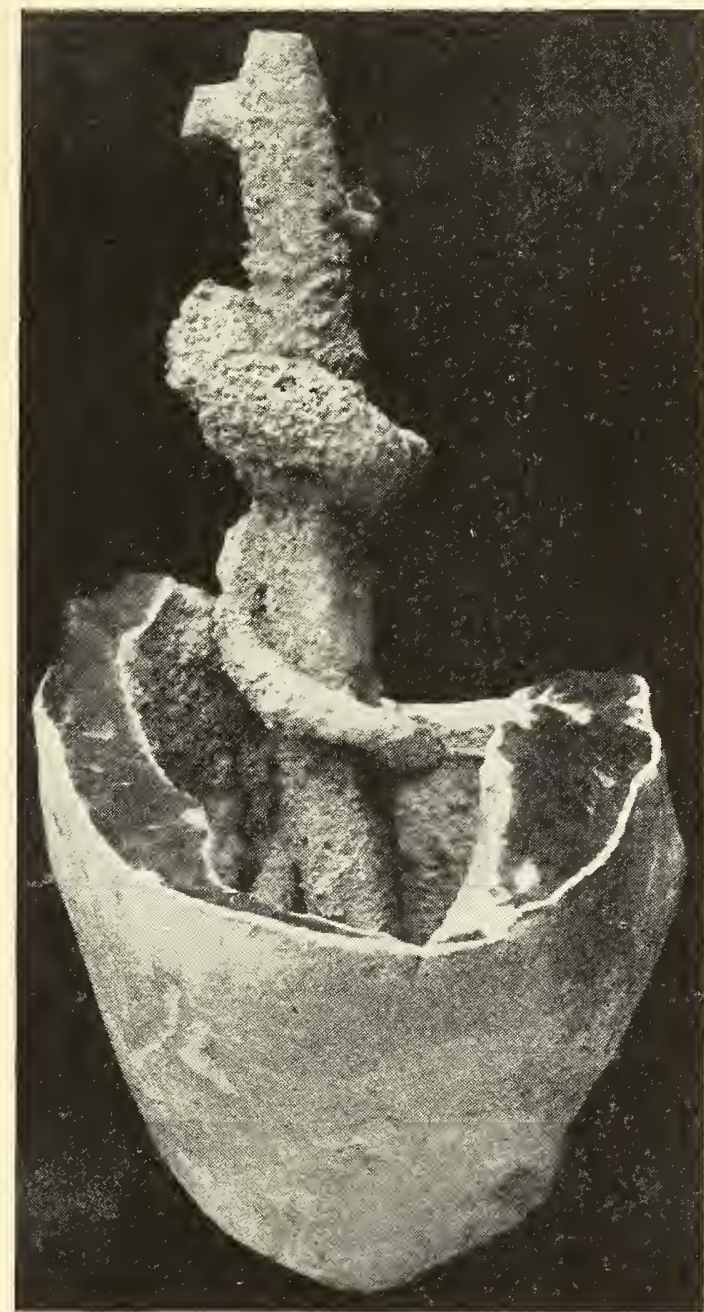

Fig. 43. A silicified sponge from the English Chalk exposing a spiral worm tube encircling the wall of the cloaca of the sponge. (Courtesy of Dr. F. A. Bather.) open cloacal cavity and remains there so that when the sponge has in adult growth built the terminal or sieveplate over its aperture the crustacean is wholly and permanently caged.

This ancient association continued long after the Paleozoic, for I have elsewhere illustrated its occurrence in the sponges of the Cretaceous from very striking specimens sent to me by Dr. F. A. Bather of the British Museum. They are here reprinted. All show a spiral worm tube encircling the long median cloaca of the sponge, in one the spiral being dextral and the other sinistral. The flat section here shown is a direct photographic print made from a thin slide and shows the actual distance of the annelid tube from the cloaca, and suggests also the presence of other commensal worms in the upper left-hand part of the sponge-body (prepared by Doctor Bather). All are from the Chalk series at Beckhampton. 


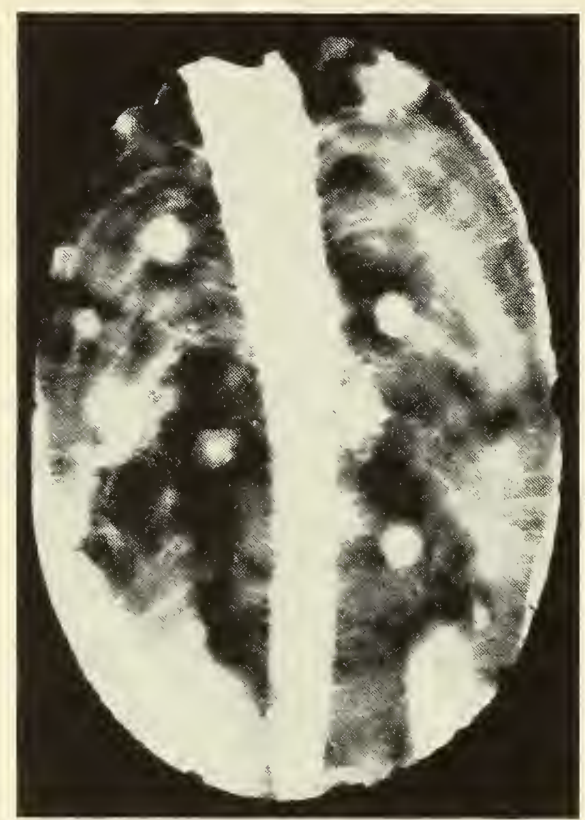

44

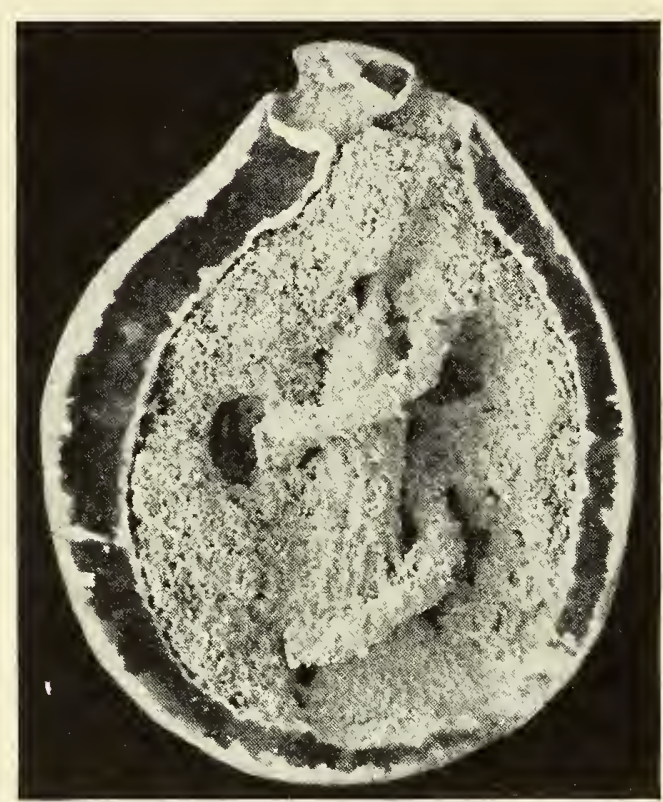

45

Figs. 44, 45. Sponges from the English Chalk showing spiral annelid tubes. In both the worm is seen to encircle the cloaca of the sponge and at some distance from it (Fig. 44, section). In Fig. 45 the direction of the spiral is the reverse of that in Fig. 43. From Beckhampton. (Courtesy of Dr. F. A. Bather.)

Symbiosis in the worms and crinoids. The data for such association are not abundant. Myzostomum, a wormlike creature, believed to be an annelid, is parasitic on living crinoids where its species cause galls or swellings by the overgrowth of the calcareous substance. On the columns of Paleozoic crinoids small gall-like protuberances are occasionally found, with a central perforation, and several authors have ascribed these to the Myzostomum. ${ }^{1}$ These Myzostomid galls (Myzostomites) have been recorded from rocks as early as the Upper Ordovician, but we must confess to knowing very little about them, and some of the pittings and depressions on crinoid columns which have been thought to be the inner cavities of Myzostomid cysts are doubtless of other origin. Perhaps the best proof that these galls have been made by infesting worms is afforded by the

1 See Wachsmuth and Springer. 1897, p. 43, pl. 1, fig. 2; p. 502, pl. 39, fig. 7 ; R. L. Moodie; F. A. Bather. 


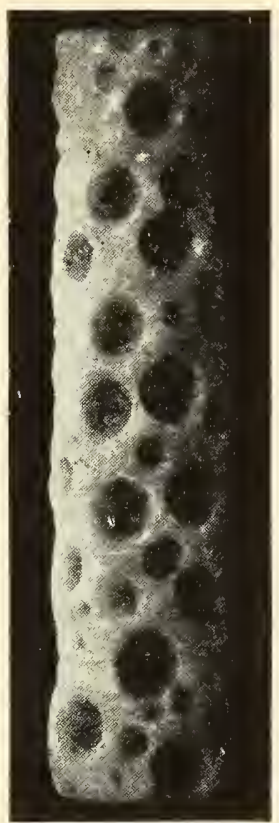

46
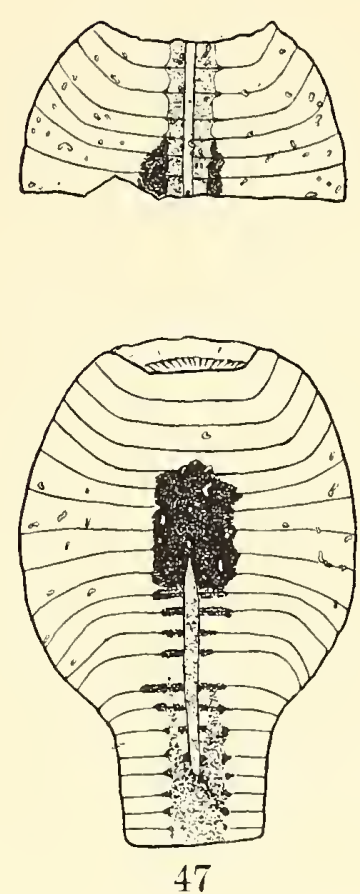

Fig. 46. A crinoid stem from the Carboniferous with deep pits over the surface which may be due to the work of Myzostomites.

Fig. 47. Transverse sections of a calcareous hypertrophy or "gall" on the jointed stem of a Devonian (Hamilton) crinoid. This shows, by etehing and transparence, the filling of minute worm like tubules in the enlarged stem joints, and a darkened aggregate at the center along the stem-canal which has been contracted and obstructed by the spread of this growth, producing a genuinely pathologic condition. Enlarged. (The specimen from which these sections were made presented by Professor George H. Chadwick.)

specimen here figured from the Hamilton shales of the Devonian.

Commensalism of coral with coral. The so-called genus Caunopora is an interesting illustration of this habit of growth. Caunopora is a compact hydroid coral with sharply defined and definitely walled tubes scattered through its substance. For a long time it was regarded as the work of a single hydroid colony, but it is now known to be a laminate hydroid overgrowing a series of erect coral tubes like those of Syringopora or Aulopora. Fistulipora occidens presents a similar coalition of a hydroid coral growing about the tubes of Aulopora. These are both Devonian oc- 




Fig. 48. Caunopora; a stromatoporoid colony showing the tubes of Syringopora, a coral that lived commensally with it.

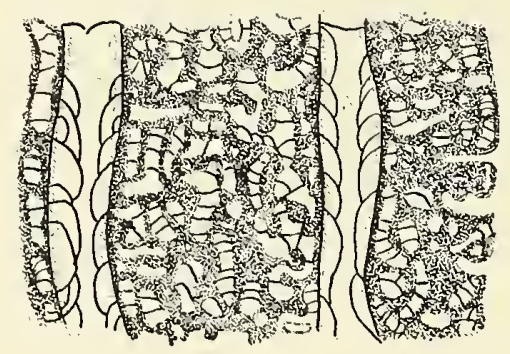

Fig. 49. Sehematic section showing the structure of the coral tubes in the stromatoporoid mass. Onondaga limestone (Lower Devonian).

currences and this association of the hydroid with the zoantharian corals is widespread. Other occurrences of this sort are well known and we figure here a colony of the honeycomb coral Favosites which has overgrown a small plantation of the cyathophylloid coral Amplexus. In all these associations there has been apparently no interference with the functions of either member of the combinations. Naturally, as these are merely incidents of their growth they have been carried onward into recent coral plantations where such combinations are not infrequently noted. 


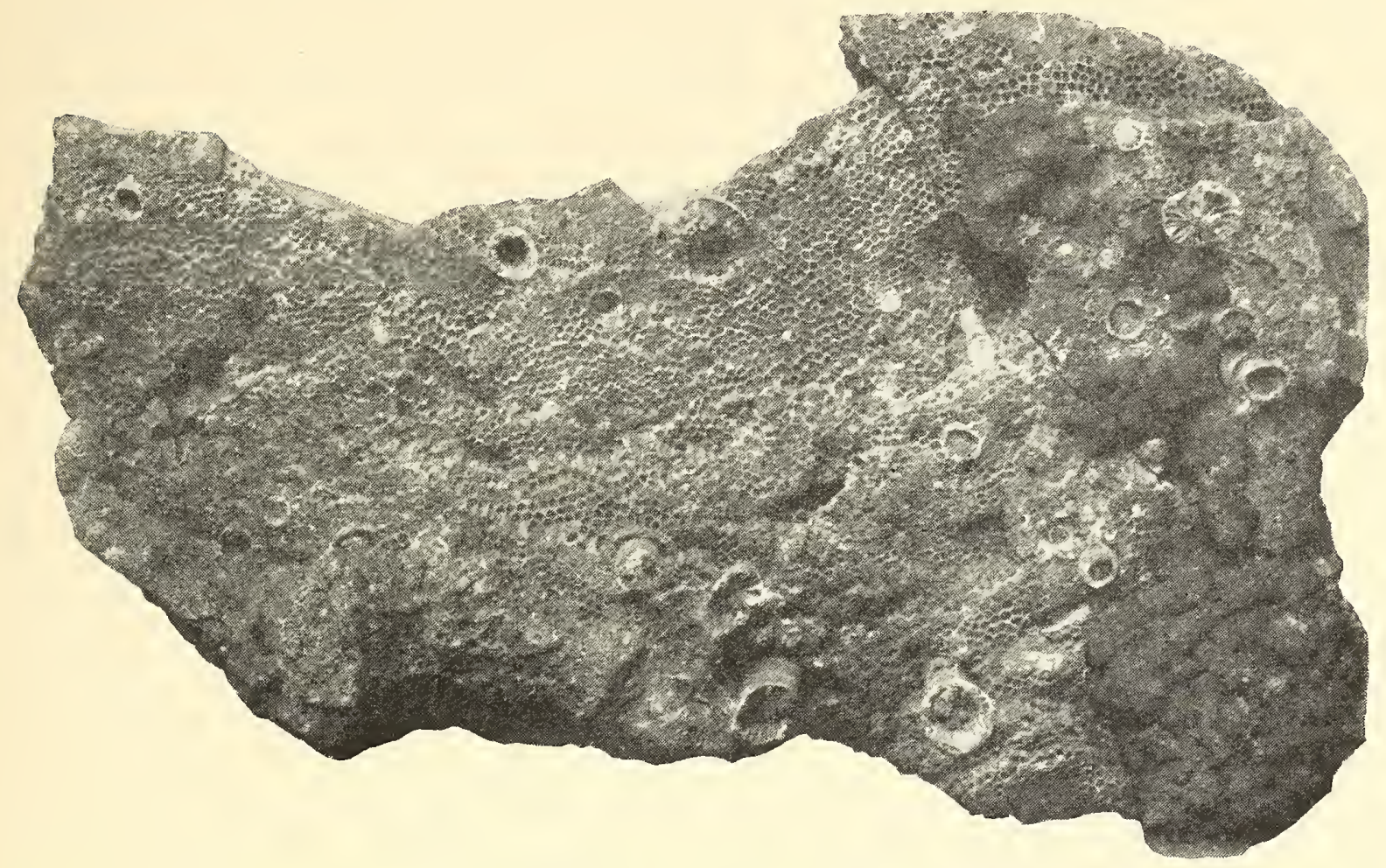

Fig. 50. A colony of the coral Farosites niagarensis which has partially overgrown a small plantation of the eyathophylloid coral Amplexus. From the Niagara formation (Silurian), Monticello, Iowa. $\mathrm{x}$ 1/2.

\section{THE BARNACLES}

It is well known that the barnacles are degenerate and attached crustaceans. The acorn barnacle with its hard valves consolidated into a cone-shaped shell, and the goose barnacle with its flat shells on clustered stems, represent for us the living members of this interesting group of recreants. $^{1}$ In the barnacle, of whichever kind, the animal has lost its independence through attachment by its head or back and the readjustment of its segmental plates to fit the demands of its stationary maturity. Ontogeny shows a free and normal larval state for the barnacle and indicates a phylogeny in which locomotive independence had been normal throughout life.

We have known for some years the existence of barnacles in the Paleozoic rocks. The acorn barnacle Palaeocreusia,

1 Far greater degeneration of anatomy and function is presented by several other forms of soft-bodied barnacles in existing seas. 
which has been found encased in a honeycomb coral (Favosites) of the Onondaga limestone (Lower Devonian), is apparently as completely degenerated as the existing barnacles. Hercolepas is an acorn barnacle from the Swedish
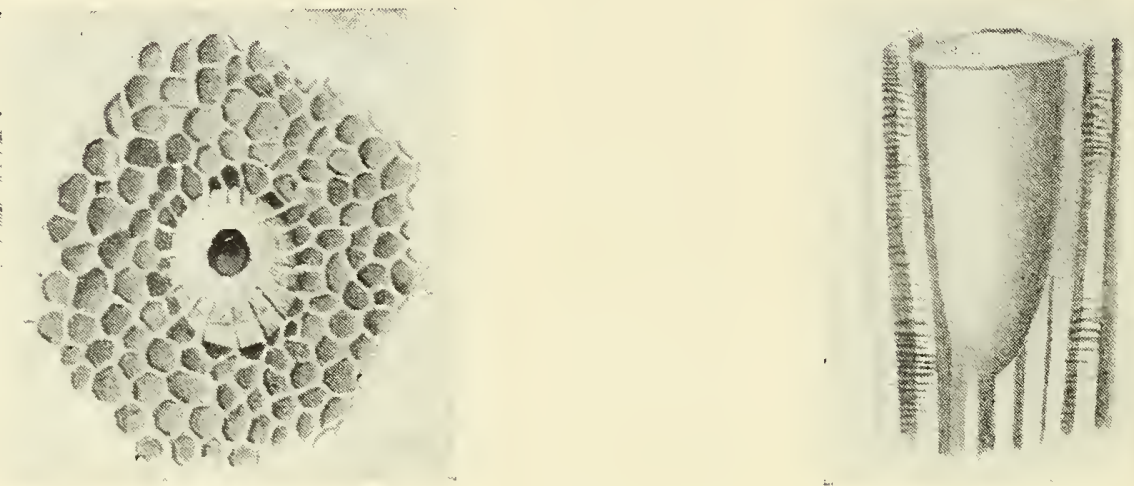

51

Fig. 51. A Paleozoic barnacle, Palaeocreusia devonica, buried partly by burrowing and partly by solution, in a colony of the coral Favosites. Onondaga limestone (Lower Devonian).

Silurian. The recent discovery by Ruedemann, to which we have referred, of a primitive Balanus in the Ordovician (Lorraine shale) attached to the shell of a cephalopod (Endoceras) and in several stages of its growth, has beautifully indicated the mode in which this degeneration has taken place. In this early species the valves are simple apposed plates, corresponding in size and number on each side, and these, the author cited believes, were developed from freeswimming phyllopods (like the Apus of present waters) of earlier faunas by two factors:

a. Fixation by the back, so as to give a better play to the feeding and breathing appendages.

$b$. Lateral stresses exerted on the long pod-shaped carapace, by the play of the currents from without and the reaction from within which eventually developed sutures where these strains were greatest.

Thus we seem to have traced back to pretty clear indications of its beginning this highly degenerate crustacean, and 
in these early presentments see that the fixation which led to recreancy was for a purpose distinctly advantageous to ease of living; that the creature became consolidated and set at a very early geological age.

For the Lepad or goose barnacles we have very much the same sort of evidence. There are much elongated flat segmented barnacles in the Ordovician known as Lepidocoleus. Others of this type occur throughout the Silurian and Devonian (Plumulites, Turrilepas, Strobilepis ${ }^{1}$ ) in which the elongated shape and the regular fore-and-aft ranges of plates are retained, but the earlier form is much the simpler, as it has but two such ranges, one on each side and both symmetrical. Attachment in all of these is by the base, that is, by one end of the shell; and we have expressed the belief that the whole stock to which these belong and which is represented by the existing Lepads arose from a like phyllopod ancestor to the Balanidae but through fixation or cementation by the head, rather than the back; a fixation which gave a similarly favorable exposure of the feeding and breathing appendages, but also induced greater exposure to lateral stresses, which has resulted in a more numerous development of sutures and valves. This attachment, and consequently the career of the goose barnacles would seem to date from approximately the same geological age as that of the Balanidae and, as we have said, to have come out of the same free and independent crustacean stock.

1 These have been commonly accepted as Cirripedia and while we are granting that the probabilities seem in favor of this interpretation, there are features of structure which suggest the sealed annelids. This comparison has not been closely carried through. 


\section{EARLY PARASITISM OF THE SNAILS UPON THE CRINOIDS}

A true parasitic combination has long been recognized among the ancient crinoids or sea lilies and the gastropods or sea snails. It began, so far as we know, in the Silurian, became of common occurrence in the Devonian and reached a climax in the Carboniferous age; and with the close of Paleozoic time, this special combination ceased or was extinguished. The history of these cases is of very large significance to our investigations. The crinoid, by the end of the Ordovician period, was fully developed and specialized. Its habit, presumably from the larval state on, as today, was one of fixation by a long highly flexible stem which remained functional, with rare exceptions if at all at this period, throughout the rest of life. It had developed a welldefined aboral or anal orifice to the curved intestine and this opening was on the upper surface of the calyx between two of the arms or in the summit of the dome embraced by these free arms. In many species of the later Carboniferous and Devonian this dome was elongated into a proboscis which carried the anal aperture upon its summit either for the purpose of conveying the rejectamenta beyond the reach of the mouth or for the actual protection of the crinoid host from the parasitic gastropod which must have been obnoxious to it as it interfered with the normal alimentary function. These suggestions will be again referred to.

The gastropod had also attained in the Ordovician a normal form, that of a simple spiral shell with a circular aperture or mouth. It was a holostomatous shell, with a continuous shell mouth, without any special adaptation for fixation by suction or otherwise to any extraneous object. The limpets had already developed, and these are shells which express even better the simple conical form out of which all the coiled gastropods had been derived. This type was primitive and both phylogeny and fossils show it to 
have been the most ancient. The first simple coiling of the shell which resulted from subsequent obstructed growth on one side of the animal could not have much altered any functions. The habit of these limpetlike shells with apical coil only (Platyceras, Capulus ${ }^{1}$ ) seems to have been then, as now, one of easy but not necessary muscular attachment to whatever body they might choose to grow on, and today we have a long list of genera, both of marine and fresh waters, in which this exterior form of shell and the internal habit are retained.

In the various expressions of conjugation between such shells and the Crinoidea we have evidence enough to trace, step by step, the progress of free and haphazard association into a fixed and dependent parasitism; a cinema of some millions of years, displaying the gradual yielding to a fixed and essentially vicious habit. It is the illustration, critical we think, as it could hardly be derived except from the paleontological record, of the passage of symbiosis into parasitism. With it the case would seem to have been made out also for the incurability, under unconscious agency, of such a "perturbation of normal activities"; for so far as we can see the habit ended only with the downfall of those crinoidal groups whose structure exposed them to these attacks.

We may here turn aside to note briefly the fact of parasitic attachments in the existing fauna, of gastropods to various representatives of the Echinoderma (starfishes, sea urchins, etc.), the group to which the crinoids belong. Tönniges has given ${ }^{2}$ a very interesting pictorial account of these, drawing in some measure on the determinations made by the Sarasin brothers. We are not much in the way of thinking of the snails as true parasites, but the author cited remarks that all of the very few species known to have

1 True eapulids of this period are doubtless reversionary forms as shown by tendency of later growth to reassume the conical shape.

2 Naturwissensch. Wochenschr., v. 19, no. 16, January, 1904. 
parasitic habits live on the echinoderms-as though the habit established in ancient Paleozoic days upon the crinoids had found favorable adjustment throughout the group. Nevertheless it is of special interest to find that one of these parasites is a limpet of essentially the same type as those which infested the ancient crinoids. This is the species Thyca ectoconcha which attaches itself to the outer skin of a starfish and inserts an extension from its snout well into the integument. The interesting statement is made that Thyca is usually a wandering snail crawling over the spines of the starfish, devouring the little sponges and their adherent organisms; in other words, lives normally until it adopts the attached and parasitic habit. The starfish has a still more degenerate parasite-snail, Stilifer, of a distinct generic type with spiral coil, which sinks itself deep in the skin of its host leaving only a minute projection of its spire, while the rest of the shell becomes enveloped in a false mantle or membrane from which a proboscis develops that penetrates far into the soft parts of the host and sucks out its nourishment. Far more extreme cases of degeneration are illustrated by the snails Entocolax and Enteroxenos, parasitic within the sea cucumbers or holothurians and which appear to have found their way in by penetration through the wall of the body. In these cases the gastropod structure is so modified in the adult, by loss of form, shell, or dental ribbon and indeed the adaptation of all the anatomy to a suctorial function, that identity is shown only by the normal stages through which the young shells pass.

Living crinoids do not escape similar infestation but not by the limpetlike snails. A. H. Clark has found Ptilocrinus pinnatus parasitized by the spiral Eulima (ptilocrinicola) which Bartsch, who describes the species, finds attached to the calyx through a veritable puncture of the skin made by a suctorial proboscis. These extreme adaptations indicate complicated conditions of parasitism which could not well belong to the less complex life of the Paleozoic. 
In tracing the history of the combination our starting point is the rich marine fauna of the Cincinnati shale which lies near the summit of the Ordovician, thus immediately antedating the advent of Silurian time. We have on a pre-

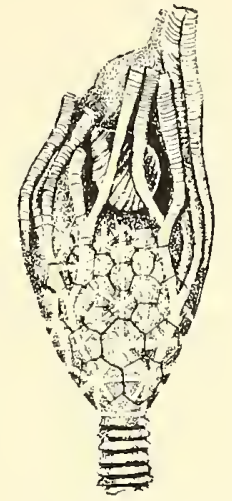

Fig. 52. The snail Cyclonema enclosed within the arms of the crinoid Glyptocrinus in an attitude of feeding. Ordovician age.

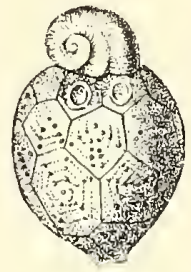

Fig. 53. A cystid, Caryocrinites carrying an attached snail which covers the apertures of the summit. Silurian age.

vious occasion pointed out the free concurrence of the holostomatous snail Cyclonema bilix, one of the abundant members of the fauna, with the crinoid Glyptocrinus decadactylus. In this case the shell is found to lie, inclosed by the arms of the crinoid, in a position that would give it full advantage of the waste from the crinoid, but without fixation. It had been drawn to the crinoid by an obvious supply of food but it was free to go and come as it was impelled. And yet the shell was of such build that its aperture was quite admirably adapted to fixation-a round thin edge without any irregularities which might lessen the effectiveness of the attachment.

If now we may turn from the crinoids to the closely allied group of the Cystids in which the alimentary parts have essentially the same alignment, we find a case, long ago figured by Hall in the "Palaeontology of New York" (v. 2, pl. $49 a$, fig. 1d, 1847), of an apparent attachment of a similar round-mouthed shell (Strophostylus) to the anal surface of the cystid Caryocrinites ornatus, of the Rochester shale 
fauna of the Silurian age. There seems no good reason for not interpreting this occurrence, even though it may be isolated, as a definite and purposeful fixation. To regard it as casual would be sophistication. With these preliminary evidences then we find the snail-crinoid adjustment well under way very early and clearly developing from a habit of visitation into a set adjustment to vitiation and parasitism.

As we enter the Devonian or next succeeding period of geological time, we are confronted at once by an enormous development of the holostomatous shells

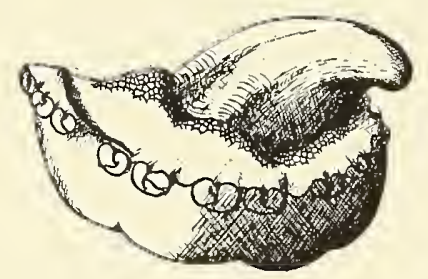
of the limpet group, known as Capulus or Platyceras, with various generic allies. They are all very closely allied to the species we have already referred to and have the same inheritance.

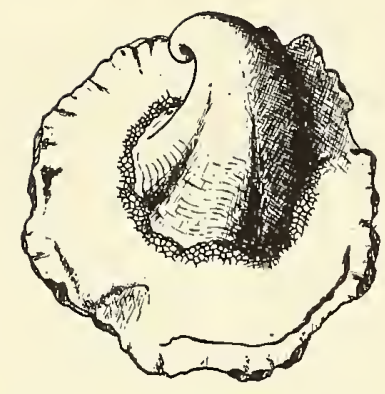

Fig. 54. Views of the Silurian erinoid Marsipocrinus coelatus (Phillips) sur mounted by, and partly enclosing an attached snail. Wenlock limestone, Dudley, England. (Courtesy of Mr. Frank Springer.) So abundant are these Devonian limpets and so great their variety that it has more than once been proposed to designate the early Devonian age by the name Capulian or Platyceras stage. In a sudden outburst of evolution these mollusks here reached their climax. Every student of these shells recognizes the difficulty of assigning specimens of them to well-defined species, because the thinness of the shell mouth and its easy adjustability in fixation to the irregularities of the surface to which they may attach themselves have caused many differences of expression. Attachment was their habit and we may expect to find them fixed to various sorts of objects, organic and inorganic, whenever they have been caught alive or in a cemented condition by the burying sediments. We must then scrutinize every 
case of such attachment to determine its casual or its intentional nature. It is in the Devonian that the growing abundance of the crinoids amid legions of Capulus begins to provide us with increasing instances of fixation of the latter to the former. The earliest of

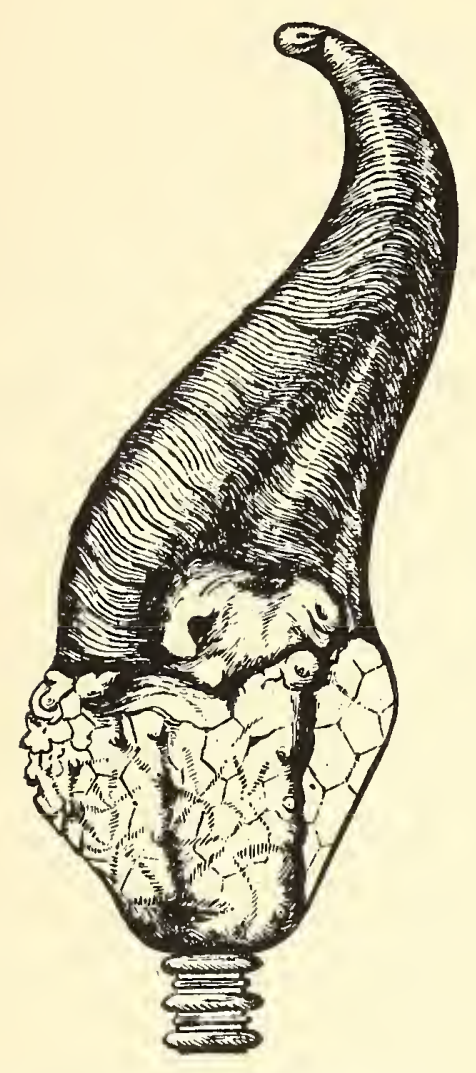

Fig. 55. Melocrimus micmac, a Lower Devonian crinoid, embraced and almost overwhelmed by a trumpet-shaped snail. all these and the most striking case on record at all, is the combination of the crinoid Melocrinus micmac Clarke with the capulid snail Orthonychia tortuosa Hall from the fauna of the Lower Devonian Grande Grève limestone of Gaspé. Here we have a small species of Melocrinus overwhelmed and borne down by a massive trumpet-shaped limpet, whose very weight must have toppled the crinoid over to the sea bottom. The aperture of the shell fits down over the entire dome of the crinoid naturally covering the eccentric aboral aperture. The attachment of the shell must have begun very early and continued firmly to the full maturity of the shell. Orthonychia is a division of almost conical or slightly twisted capulids, the spire being apical and incipient or altogether absent. Such shells have not before been seen in this attached condition; they were not adapted to it, for their uncoiled form would make the crinoid so top-heavy that the whole combination would succumb. It is therefore not surprising that this record does not repeat itself. ${ }^{1}$

Craterocrinus ruedemanni Goldring is a species as yet

1 This specimen of $M$. micmac is the only crinoid ever found in the profuse Grande Grève fauna. It was obtained by the writer from a ledge a half fathom under water at low tide. 
described in manuscript, ${ }^{1}$ taken from the Onondaga limestone of New York. It is like Megistocrinus in its general form with a broad upper surface or tegmen and very large aboral opening. Our illustration shows a specimen of this

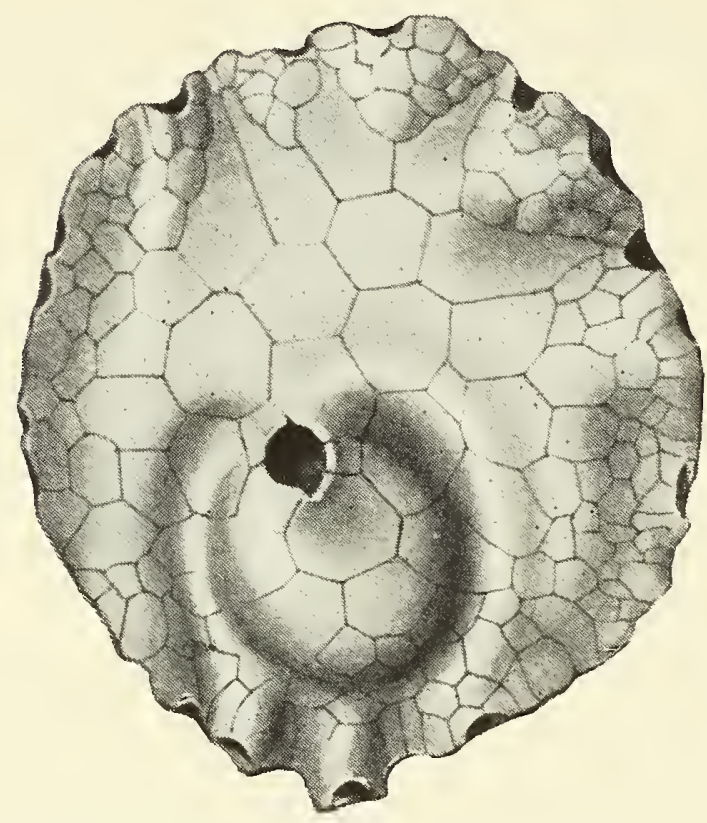

Fig. 56. Upper surface or dome of erinoid (Craterocrinus) with anal opening and sear of shell attachment. Devonian.

crinoid with the scar of attachment made by a shell which became fixed early and clung to its situs throughout life, the enlarging scar growing eccentrically from the anal aperture, and leaving a deep sinus about the bulging. adjoining portions of the growing crinoid.

In the Middle Devonian Hamilton shales of Thedford and Bosanquet, Ontario, occurs the platycrinid species Hystricrinus carpenteri Hinde, a peculiar genus with surface spines jointed to the calyx by a ball-and-socket arrangement. The species is known only in the shales of these localities. Two species of gastropods have been found attached to the aboral surface and dome; one a smooth form, Platyceras erectum Hall, and the other a spiny shell which has been incorrectly called $P$. dumosum Hall. These shells have not been found attached to any other crinoid and no other crinoid of the Hamilton shales in that vicinity has thus far shown evidence of such combination. This combination is thus closely restricted locally. The crinoid with its broad tegmen or vault, diffuse arms and absence of anal proboscis, offers every convenience for this adjustment, but

1 By Winifred Goldring in preparation of a Monograph of the New York Devonian Crinoidea. 
nevertheless there were lacking in this local fauna neither crinoids nor snails of other species. The limpets are of the usual type with small spires and broad whorls and not unlike each other in general proportions. Hystricrinus.punctobrachiatus Hall, which occurs in the same fauna, carries

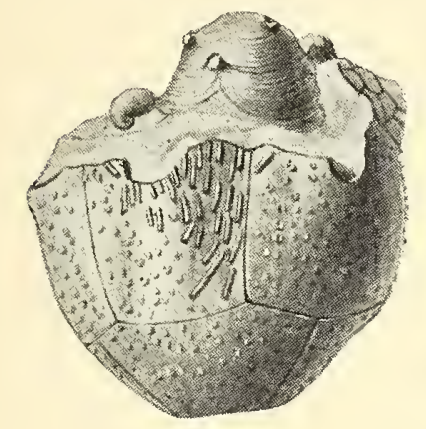

a

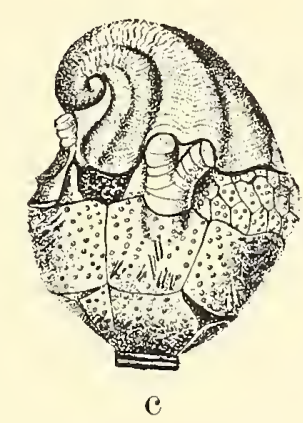

C

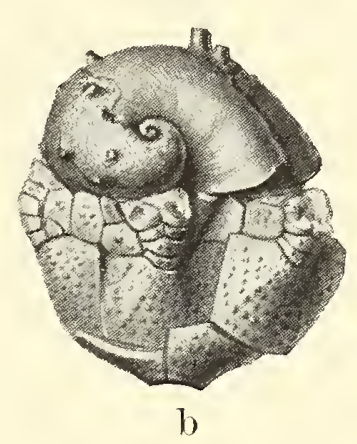

b

Fig. 57. Two specimens of a spiny crinoid, Hystricrinus, with two different species of snails. Devonian.

no parasite so far as known and the later species of the genus ( $H$. ithacensis) is without such associates. The directive impulse indicated in the adjustment of the limpets to these crinoids is here undeniably clear.

From the Middle Devonian limestone fauna of central
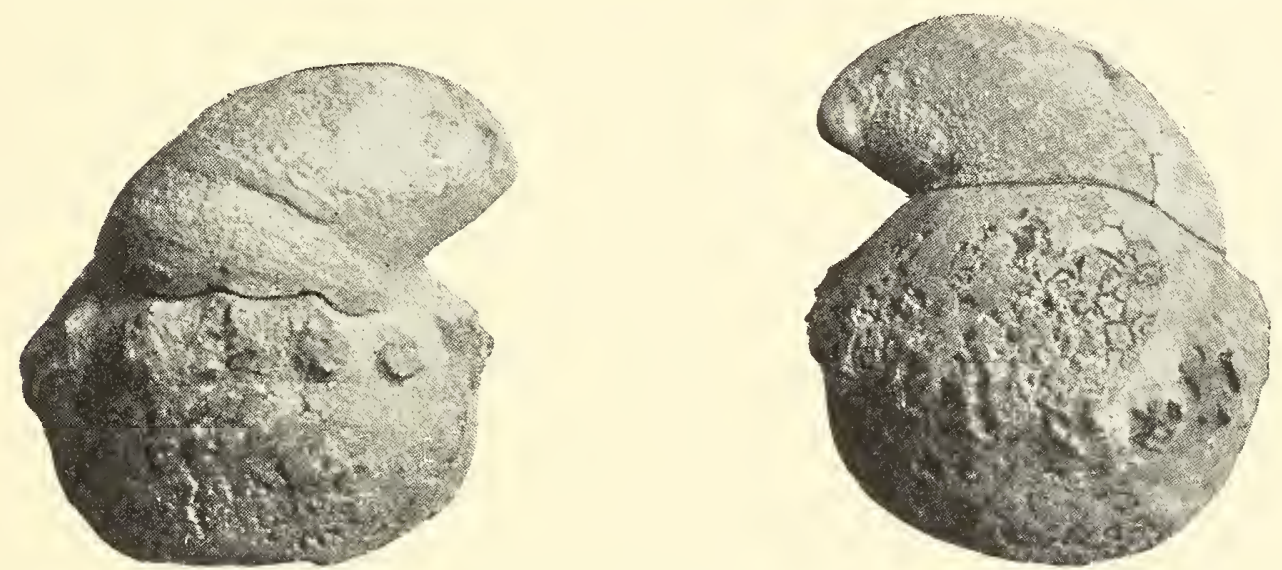

Fig. 58. Two views of the calyx of Megistocrinus with attached Platyceras. Middle Devonian.

Iowa we have heretofore recorded the combination between the crinoid Megistocrinus farnsworthi White and a large Platyceras. This is known only in a single case and, as shown by the figure here given, the evidence of gradual 
growth and expansion of the shell after attachment was effected, is seen in the adaptation of the latter to the irregularities of the crinoid dome. The adjustment perfectly covers the anal region and is so effected as to avoid unprofitable surfaces.

In all the crinoids taken from the extensive plantations uncovered at Vincent, N. Y., in the Hamilton shales (Middle Devonian), the most striking assemblage of these fossils ever found in the Devonian rocks, not a single instance has been observed of this conjunction. We have, however, a unique occurrence from another locality, of one of the species represented in this colony,

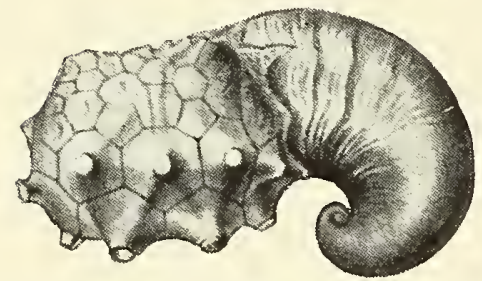

Fig. 59. Rhodocrinus ealyx with heavy snail shell over anal aperture. Middle Devonian. Rhodocrinus spinosus Hall, in which a very marked case of this parasitism is displayed, the gastropod covering the aboral orifice with the anterior part of its mouth, the rest of the aperture extending downward over the sides of the calyx. This is frequently a well-marked and perhaps normal position for the shell, and the necessity of keeping the mouth close to the source of food, forces the shell growth to be eccentric from this point and thus permits the shell margin to expand in any convenient direction.

In the Upper Devonian we have record of attachment of a broad-mouthed capulid to Melocrinus hieroglyphicus Goldfuss and a smaller species to M. globosus Fraipont. These are from the Frasnian rocks of Senzeille, Belgium, and have been figured by Fraipont. ${ }^{1}$ They are sufficient proof of the widespread practice of this parasitism in the Devonian age.

1 "Ann. Soc. Geol. de Belgique," Mem. X 1883, plates 2 and 5. Fraipont thinks the latter case mentioned in which the attached capulid spreads over the side of the calyx, merely casual commensalism, but it is evident that the shell covers the position of the anal orifice. 


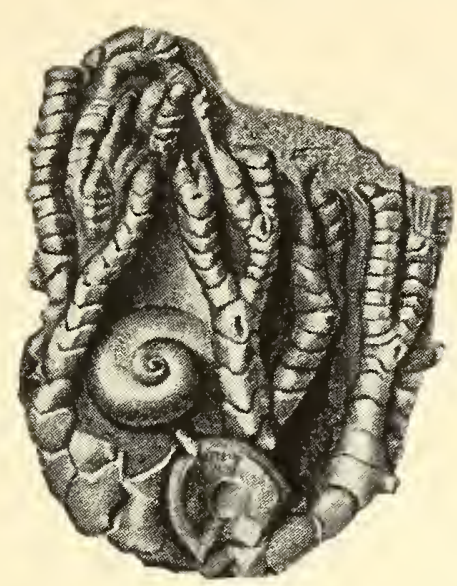

a

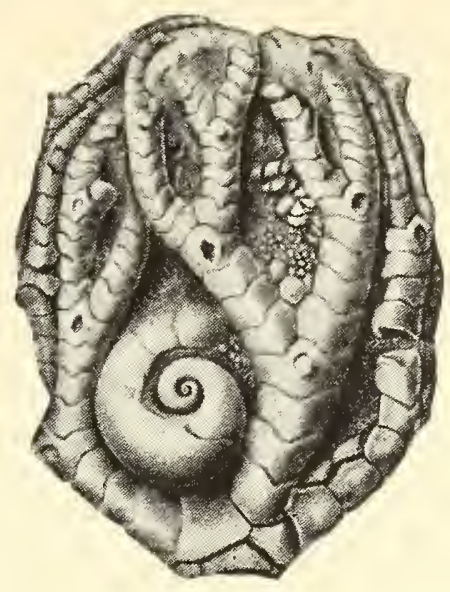

$\mathrm{b}$

Fig. 60. Two specimens of the Devonian crinoid, Taxocrinus lobatus Hall, with a coiled snail (Platyostoma) attached to the dome. Canandaigua Lake, N. Y. (b. by courtesy of Mr. Frank Springer.)

A singular and single instance of similar concurrence has been found in the Portage Upper Devonian (West Hill shales) of Naples, N. Y., a baby Melocrinus, not above onehalf inch in length (calyx) to which is attached a baby Platyceras of about the same size. This is a convincing' evidence of the early age at which this adaptation became effective, though it is no proof that the conjunction may not have been broken in later life. It is certainly extraordinary that this parasitized young condition is the only one recorded in these rocks, while Melocrinus is the only abundant crinoid in the Lower Portage fauna.

The Devonian faunas, in these cited instances, have thus furnished us with instances of the growing habit of this parasitic attachment. We find it to be occasional and sporadic, desperate and often ill-adjusted arrangements which seem to have brought disaster to the hosts. We see cases, as Melocrinus mic-

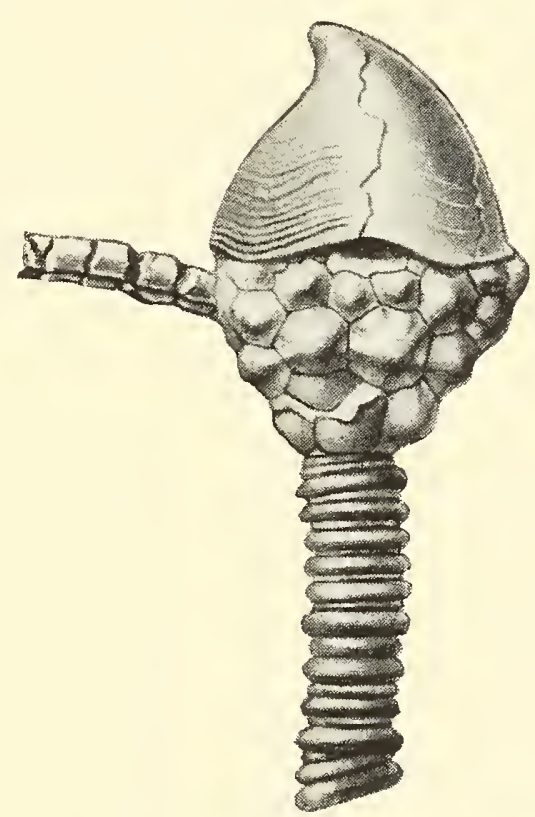

Fig. 61. Young Melocrinus with young snail attached. Upper Devonian. 
mac, Rhodocrinus and Melocrinus sp., where disproportionate growth of the gastropod evinces lack of advantageous gravitational balance such as is seldom to be found in the following period when the parasitism had become set. We observe a greater variety in the form of the snail than appears later, and it is evident that some of these were better adapted than others to this mode of life. And we also see, from the instance of conjunction at a very early age in both parties to the combination, that the habit must be a long-time inheritance out of the past.

We may now consider the expression of this parasitic adjustment as it appears in great frequency in the marine faunas of the next or Carboniferous age, especially in the calcareous deposits which compose the earlier or, as called in this country, the Mississippian stage of this series.

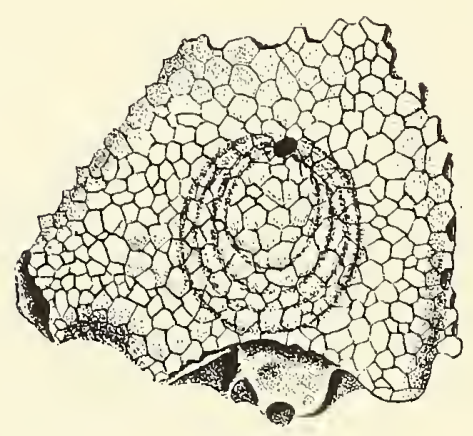

62

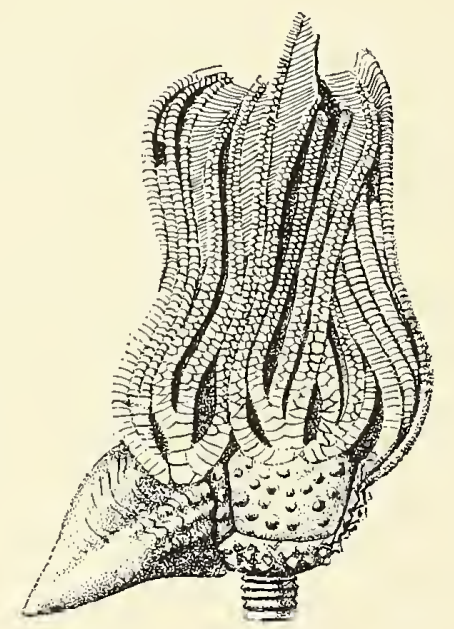

63

Fig. 62. Part of the dome of the erinoid Strotocrinus showing successive growth scars made by an attached Platyceras always keeping its anterior extremity over the anal aperture of the erinoid. Mississippian. (After C. R. Keyes.)

Fig. 63. The crinoid Platycrimus hemisphaericus with the snail Platyceras infundibulum attached. Mississippian. (After C. R. Keyes.)

Such concurrences are noteworthy for the evidence they bring of the general dissemination of this habit which now attains its climax. So general is it that paleontologists have recognized the difficulty of determining the species 
characters of the capulids because of the shell deformations resulting from these attachments. So far as we have succeeded in listing these concurrences they are shown in eighteen species of crinoids. Doubtless others have been recorded which we may have overlooked. It was a matter of comment by Meek and Worthen, who first took especial notice of the frequency of these combinations, ${ }^{1}$ that certain crinoids seemed always to carry certain snails, intimating thus a definite affinity of one for the other; and to anyone confronted by an array of these combinations this purposeful predilection is very impressive.

\section{List of Recorded Carboniferous Crinoids with Parasitic Gastropods ${ }^{2}$}

1. Platycrinus hemisphericus Meek and Worthen.

2. P. pileiformis Hall.

3. Strotocrinus regalis Hall.

4. Gilbertsocrinus tuberosus Lyon and Cassiday.

5. G. typus Hall.

6. Dorycrinus immaturus Wachsmuth and Springer.

7. Agaricocrinus americanus Roemer.

8. Pterotocrinus acutus Wetherby.

9. P. bifurcatus Wetherby.

10. P. depressus Lyon and Cassiday.

11. Physetocrinus ornatus Hall.

12. P. ventricosus Hall.

13. Eucladocrinus millebrachiatus Wachsmuth and Springer.

1 "Geological Survey of Illinois,"' v. 5, 334. 1873.

2 We are greatly indebted to Dr. Charles $\mathrm{R}$. Keyes for his investigation and record of these associations as registered in literature and in the extensive collection of erinoids at that time belonging to Dr. Charles Wachsmuth, now by the generosity of Mr. Frank Springer the possession of the National Museum. Doctor Keyes's papers on this subject of the species of Platyceras which consort with the Mississippian crinoids were printed in 1888 ("Proe. Amer. Phil. Soc.," v. 25) and 1890 ("Proc. Acad. Nat. Sci.,' Phila., v. 42). 
14. Actinocrinus verrucosus Hall.

15. A. multiramosus Wachsmuth and Springer.

16. Acrocrinus shumardi Yandell.

17. Poteriocrinus coccinus. ${ }^{1}$

18. Cromyocrinus simplex Trautschold. ${ }^{2}$
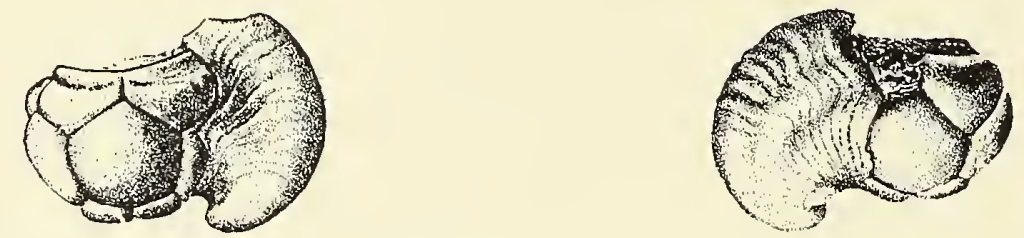

Fig. 64. Cromyocrimus simplex with attached snail of large size, its anterior portion covering the anal aperture. Carboniferous limestone, Russia.

In order to show that in the study of this adaptation between crinoid and snail we are not being misled by appearances, let us look a moment to the mode of evolution of the excurrent aperture in the crinoid and the effort made by the crinoid host to protect itself against this disadvantageous parasitism.

1. In the crinoids of the Ordovician and Silurian, where this adjustment first appears, there was only a smoothdomed tegmen between the arms and, with these arms floating expanded in search of food, the dome with its anal aperture was a freely exposed surface, an open invitation to such attachment as ensued. There were, however, plenty of crinoids of that period provided with anal tubes, that is, plated extensions of the tegmen or upper surface into proboscis-like shapes, bearing the anus at their extremity, and the purpose of this combination seems to have been to raise the rejectamenta well above the mouth of the crinoid. ${ }^{3}$

On this matter Wachsmuth and Springer ${ }^{4}$ have written:

1 An uncertain species, thus spelled by Keyes but not otherwise known.

2 From the Moscovian limestone of Russia.

3 Among these genera are Diabolocrinus and Deocrinus of the Ordovician; Lampterocrinus, Siphonocrinus, Lyriocrinus, Eucalyptocrinus, Callicrinus and Chicagocrinus of the Silurian.

4 1897, “N. Amer. Crimoidea Camerata,'” p. 135. 
"As a rule, a tube occurs more frequently among species in which the arms form a continuous series around the calyx, while species in which they are arranged in clusters often have a simple opening." And it also appears that this tube was of convenient rather than essential function. The animal could live without it when it was broken off or obstructed, and easily made a new orifice when necessity required.

2. It appears, however, that early attachment may have prevented the development of the anal tube. This would, indeed, seem to be indicated by the specimen of Craterocrinus ruedemanni here shown, where the attachment beginning very early prevented the development of an anal tube which would have been normal to this type of structure, or at least is normal to all other member's of the family to which this belongs - the Dolatocrinidae.

3. In general, crinoids which have been found to bear parasitic gastropods have no anal tube but only a slight protuberance. Exceptions to this statement are rare and of uncertain value. Actinocrinus verrucosus Hall has an anal tube but a specimen is reported by Keyes, with an attached snail. ${ }^{1}$ In this crinoid, however, it appears that the tube has been broken off and an aperture developed on the dome. Wachsmuth and Springer refer to Actinocrinus multiramosus in which this anal tube is retained and a gastropod is attached to the tegmen below. ${ }^{2}$

4. The parasitic condition so rampant in these early Carboniferous ages disappeared entirely so far as present records indicate, with the disappearance of the fauna from the various shallow seas of the world. There are instances of the continuation of some of these parasitized genera of the Mississippian into the marine faunas of the Coal Measures (that is, Aorocrinus) but in none is the condition of

1 Keyes, 1888, pp. 235, 237.

2 1897, “'N. Amer. Crinoidea Camerata,', p. 566. 
parasitism continued. The habit was extinct; I think we may say that this particular adjustment had been extinguished.

\section{SYMBIOTIC CONJUNCTION OF CRINOIDS AND STARFISHES}

This is a habitude which, so far as known, is exhibited only in the Mississippian fauna of the Lower Carboniferous and on its face it would appear to be a purely voluntary association, as there is no anatomical evidence that the starfish has sacrificed its locomotive

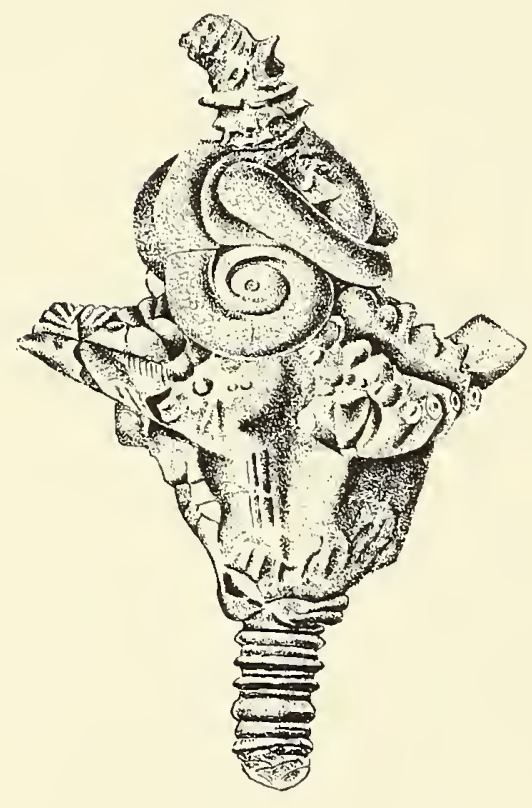

Fig 65. The crinoid Actinocrimus multircmosus with a starfish (Onychaster) attached to the anal tube. (After Wachsmuth and Springer.) function and none that the adjustment is essentially unlike the association between Glyptocrinus and $\mathrm{Cy}$ clonema. The known facts regarding the combination are interesting. The starfish is Onychaster flexilis Meek and Worthen; it has rarely been found undetached. The crinoid seems most commonly to have been the high-domed species Actinocrinus multiramosus. Wachsmuth and Springer ${ }^{1}$ tell of finding forty specimens of this crinoid in the Crawfordsville shales of Indiana, of which nearly one-half had the attached starfish, and these authors were strongly disposed to the view that, because of the elevation of the anal tube and the situation of the waste aperture near its apex in a position seldom if ever covered by the mouth of the starfish, the association was one of comfortable attachment only. Reference is made by the same writers to the fact that this starfish at the locali1 1897, "N. Amer. Crinoidea Camerata," p. 566. 
ties of their observation occurs on no other crinoid species except Scytalocrinus robustus, which also possesses a long anal tube but with the aperture far down toward the base and within easy reach of the starfish. We here illustrate a Barycrinus (B. Hoveyi Hall), a species without anal proboscis, engaged with this starfish. No evidence exists that this habitude continued beyond the Lower Carboniferous. One familiar with the feeding habits of the starfish from ancient Devonian times to the present would be disposed to suggest that the association under present consideration can be only for feeding purposes. That this may have been "a favorite resting place" (Wachsmuth and
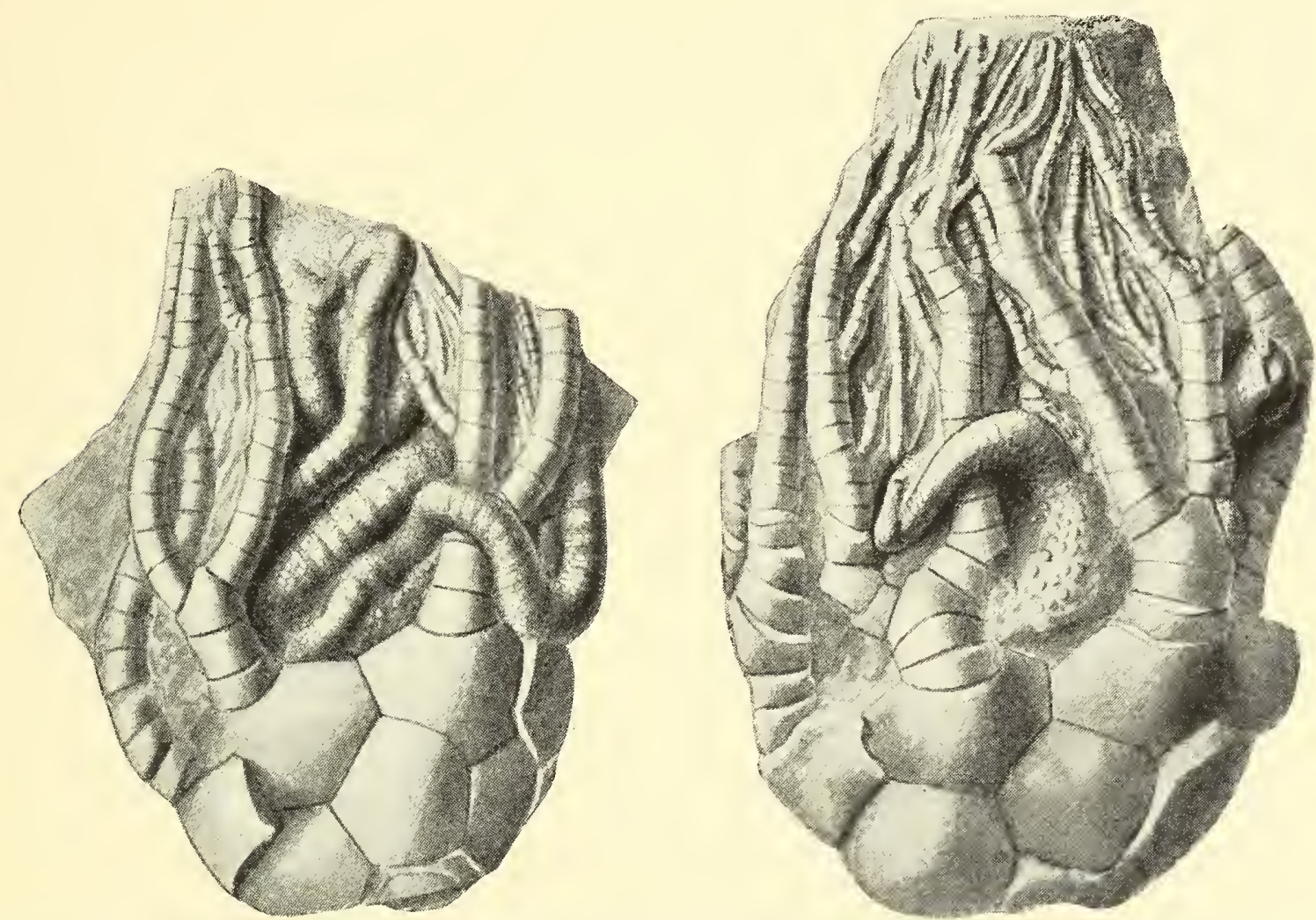

Fig. 66. The crinoid Barycrinus Hoveyi with the starfish Onychaster flexilis intertwined with the arms. Mississippian.

Springer) for the starfish will hardly explain it. The small boy in an apple tree is not there to rest. This affiliation, its constant recurrence always between the same species of starfish and a very few species of contemporary crinoids; limited apparently to the very brief period which repre- 
sents only the life of the species Onychaster flexilis, may have been an attack upon the crinoid animal through its oral aperture. But whether it intimates an actual state of dependence or might under favorable circumstances have developed into a true parasitism we do not have to decide, as nature quickly wiped out the combination through causes which we cannot know.

\section{THE WORK OF PSEUDOPARASITIC BORING ORGANISMS}

On almost every sea beach one can find the shells of dead or living mollusks bored full of minute tubes. No skeleton of the sea, except those essentially free of lime, escapes the attack of the borers. And as our present beaches and sea grounds abound with these things, so did the seas of the Paleozoic ages.

Such borings and borers have been much studied in their living form, an interesting literature has grown up about them, and perforations of like character in ancient fossils have been occasionally noticed. There can be no denial of their important present and past activity in the breaking down of accumulated lime and its return to the sea waters. Kölliker ${ }^{1}$ pointed out in much detail the general diffusion of certain boring "vegetable parasites" among the many varieties of calcareous shells in the existing fauna and he, with others, the vast total of dissolution of lime wrought by this agency alone. Such shell perforations have been ascribed to different organisms, both animals and plants; to the algae and fungi, to the boring sponges and to the boring worms. The more conspicuous rock excavations made by such boring mollusks as Teredo and Pholas ${ }^{2}$ and nestling

1 Annals and Magazine of Natural History, ser. 3, v. 4, p. 300. 1859; Zeitschr. f. Wissensch. Zoölogie, v. 10, p. 215, pl. 15, 16. 1860; Quar. Jour. Microscop. Sci., v. 8, p. 171. 1860.

2 Boring mollusks are known from Paleozoic seas and Whitfield has figured such an occurrence (Corallidomus concentricus in the coral Labechia) from the Ordovician of Ohio (see "Geology of Ohio," v. 7, p. 493, pl. 13. 1893). 
cavities made by certain sea urchins are not included in the present category.

Plants. Our attention may be given first to the plant parasites of the Paleozoic rocks. These are invariably very minute filamentous tubes often showing the swellings of hyphae or sporangia. There has been a constant and continuing difference of opinion among the students of the living forms of such boring plants, as to whether these are to be regarded as fungi or algae. Kölliker ${ }^{1}$ believed them all to be fungi, as he could not satisfy himself that the filaments in the living forms showed cell partition. Loomis ${ }^{2}$ has also identified as fungi such occurrences in the Clinton (Silurian) fauna of New York; while Wedl regarded the living forms as algae ${ }^{3}$ and Duncan, ${ }^{4}$ who specially studied these borings in fossil corals of the Silurian, Devonian and Tertiary, agreed in regarding these minute tubules the work of unicellular algae. Naturally the distinction in the fungous and algal character of these borings in the fossil state is very difficult, and for our present purpose not of high importance. Duncan gave a common name to all these coral-boring plants regardless of geological age; Palaeachlya perforans, and determined them in the Silurian coral Goniophyllum pyramidale, the Devonian coral Calceola sandalina; also in a Silurian Cyathophyllum and an Ordovician "Foraminifer from Canada," whatever this last may have been.

The clearest light upon the nature of these boring plants has been given by the botanists Bornet and Flahaut ${ }^{5}$ after exquisite operations in the isolation of the plants from their stony matrix. These investigators were able to determine from growth-habit, structure, sporangia and fruit, that the

1 op. cit.

2 F. B. Loomis. N. Y. State Museum Bul. 39, p. 223. 1900.

3 Sitzungsb. d. k. Akad. d. Wissenseh. v. 33, p. 451, pl. 1-3. 1858.

4 Quar. Jour. Geolog. Soc. London, v. 32, p. 205, plate. 1876.

5 "Sur les algues perforantes," But. Soc. Botanique de France, v. 36, p. 147. 1889 . 
living plant borers were chiefly green and blue-green algae, only two of their species being recognized as having a probable affinity with the fungi. In a very instructive paper by Duerden $^{1}$ on the effect of these algae in the disintegration of recent corals, it is remarked that the red algae also have now been recognized among these borers.

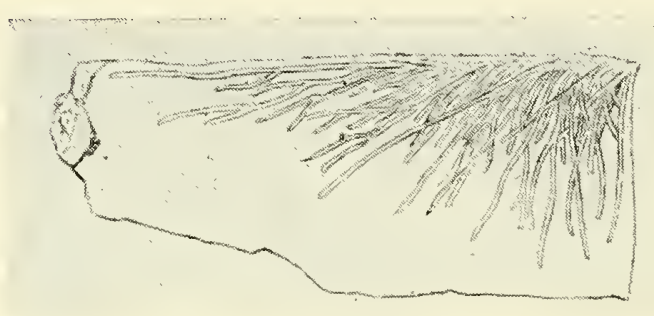

a

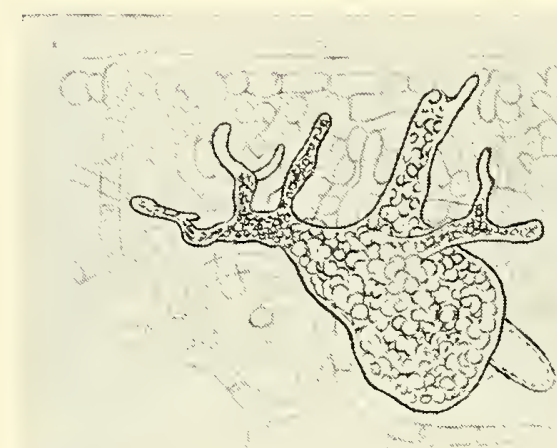

C

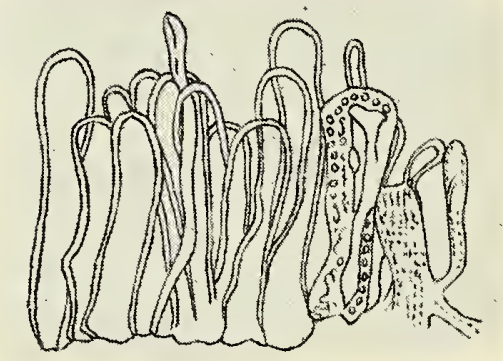

$\mathrm{b}$

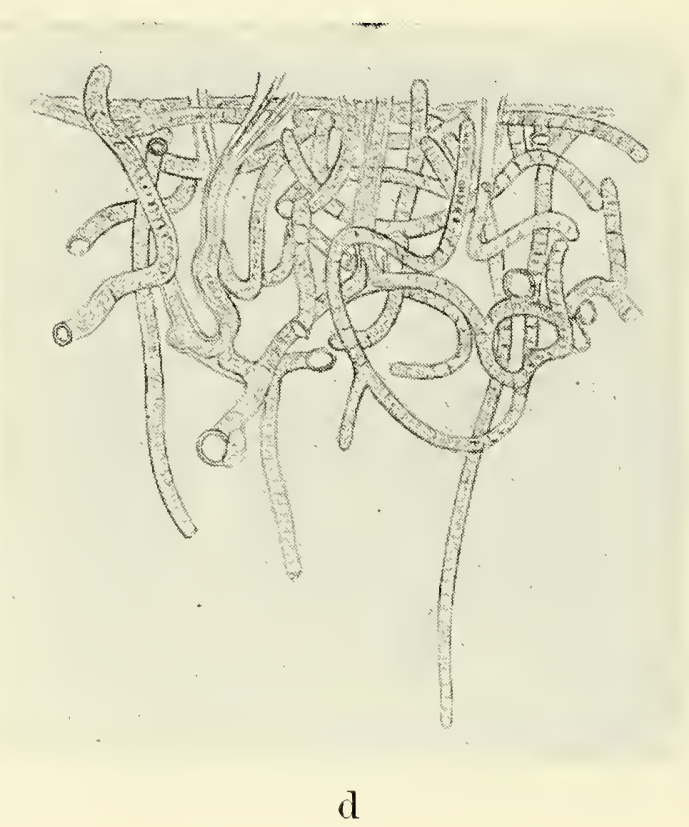

a. Siphonocladus roluticola Hariot. $\mathrm{x} 80$.

Fig. 67. Boring Plants (recent).

b. Gonontia? x 250. c. Gonontia polyrhiza Bornet and Flahaut. x 250.

d. Mastigocoleus testarum. x 330. (After Bornet and Flahaut, op. cit.)

That the debris of the Paleozoic beaches and the shallow grounds of the sea, the living as well as the dead shells, were abundantly attacked by these microscopic plant para-

1Bul. Amer. Mus. Nat. Hist., v. 16, p. 323, pl. 32. 1902. 
sites has been very obvious to the writer in his studies of twenty-five years ago on the intimate structure of the shell in the ancient brachiopods. In brachiopods, wherever the secondary change in the shell substance has been so gradual as to cause no disturbance of the fibrous tissue and of the vertical perforation which is normal to much brachiopod shell tissue, these vagrant filamentous tubes are readily recognized and often evident. Such borings are exceedingly abundant in the Devonian corals. If they have been less often seen in the acephalous mollusks it is perhaps because the secondary shell substance is less perfectly replaced. I think paleontologists who have given their attention to such microscopic structures would be well agreed that, for the brachiopods and corals at least, objects which presented freest opportunity for attack, these riddling algae were far more abundant in the Devonian than in the Silurian and Ordovician; though the evidence of their abundance even in the Lower Ordovician sea under conditions in which hematite iron is segregated in shoal waters, has been given by Hayes ${ }^{1}$ who, with the approval of Gilbert Van Ingen and W. O. Howe, refers them to the bluegreen algae. The existence of such algal borings in the scales of cretaceous fishes has been recorded by Wedl ${ }^{2}$ and by Rose. ${ }^{3}$ The heavy plates of the Devonian fishes would seem to have afforded favorable conditions for such operations but they have not thus far been searched.

We have no clew at all to the inception of this very extraordinary adjustment or of the mode of acquirement by the filamentous plants of the singular property of dissolving or otherwise excavating their tubes in hard organic lime deposits. How the work is done by the plant is still, amid various suggestions of chemical and mechanical ac-

1 A. O. Hayes. The Wabana Iron Ore of Newfoundland: Canadian Dep't Mines; Geol. Survey, Mem. 78, p. 75, pl. 1. 1915. The colored plate shows coiled tubules in the nucleus of the iron spherulites.

2 Wedl. Op. cit.

3 C. B. Rose. Trans. Microscopical Soc. London, n.s., v. 3, p. 7, pl. 1. 1855. 
tivities, an unsolved problem. This activity of course plays a large part in the scavenging process which helps to clean

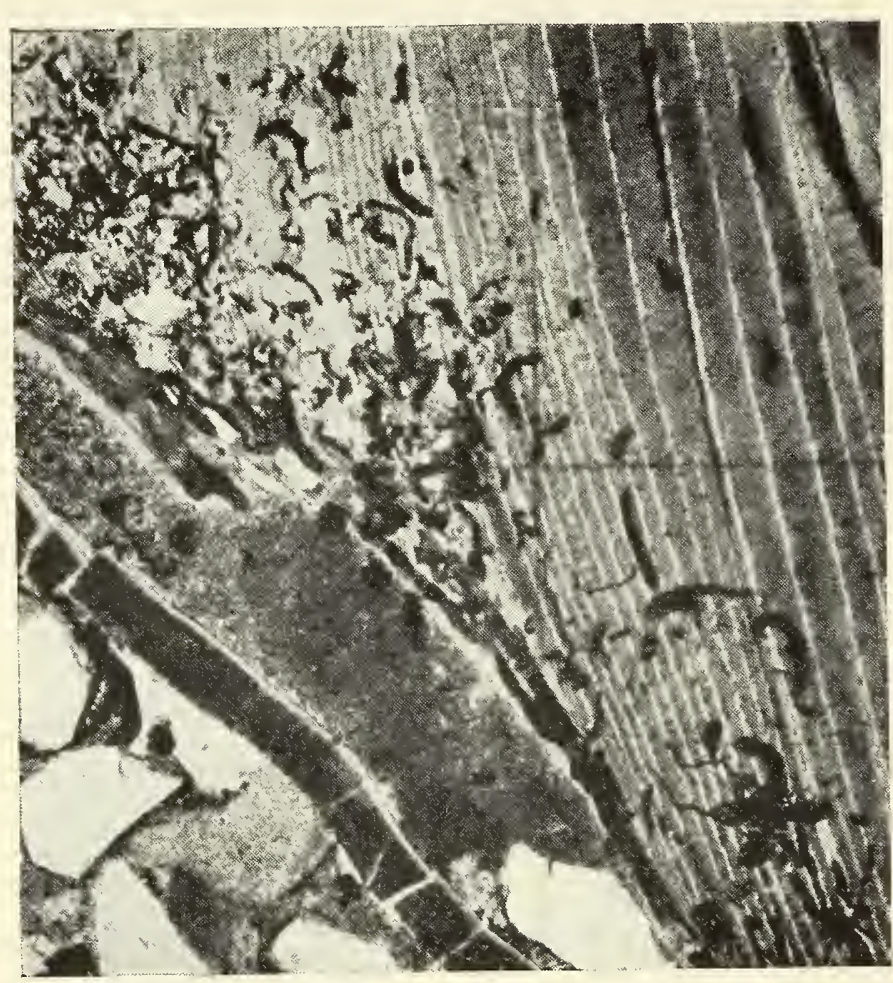

a

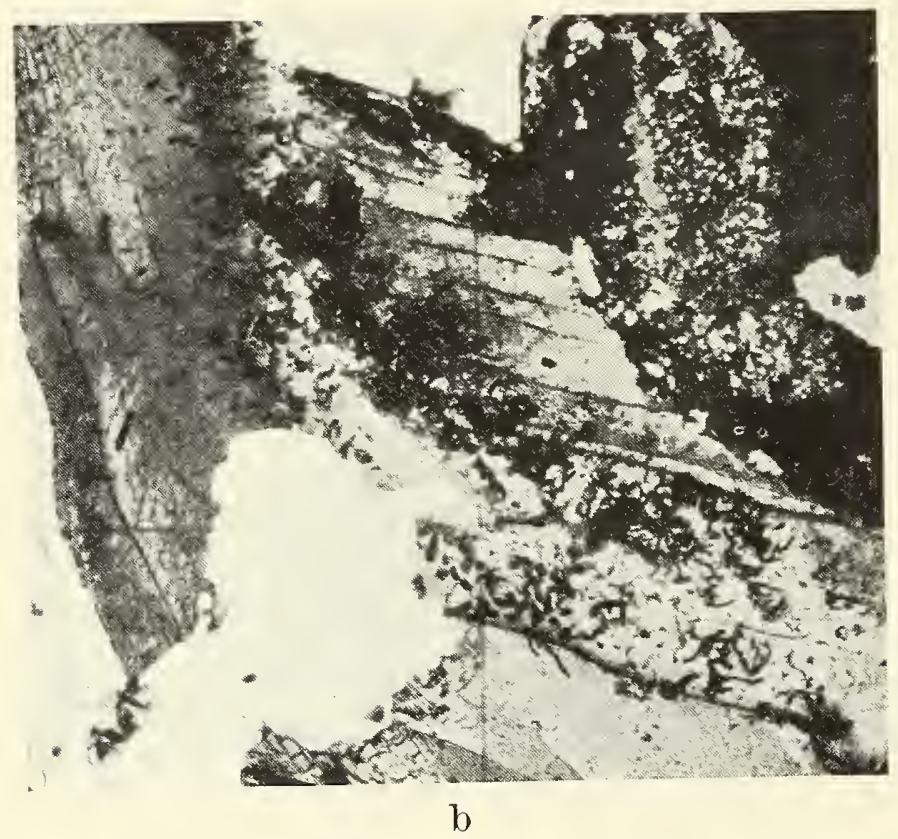

Fig. 68. Perforating algae Hayesia hematitica in the shell of the brachiopod Lingula. From the iron beds of the Wabana series (Ordovician). Conception Bay, Newfoundland. a. $\mathrm{x} 110 . \quad$ b. $\mathrm{x} 100$. (A. O. Hayes, op. cit.) up the organic excesses and restore the inorganic balance of nature. If algae can cause the deposition or secretion of lime carbonate, as they began to do on a vast scale even in Precambrian times, and do this in effect by extracting the excess molecule of carbon dioxide from waters carrying lime carbonate in solution, it seems reasonable to believe that in the same early ages algae might also have been the instruments of lime solution by virtue of the excessive atmosphere of carbon dioxide which they of necessity carried about them. Generally estimated we must ascribe to these plant parasites an early adaptation and an increasing activity which seems to be in fair correspondence with the increase in lime-shelled invertebrates. Unknown hith- 
erto in the Cambrian, occasional in the Ordovician, more common in the Silurian, they became abundant and widespread in the Devonian and thence onward to the present fauna and their activities now are known not to be confined to the salt waters only. ${ }^{1}$

Sponges. Excavations which seem referable to the activities of perforating sponges of types comparable to the living Cliona and Thoosa, which are familiarly known to bore in calcareous remains, have been observed by us in various brachiopod and acephalous shells of the Devonian. Our record of them does not extend into the earlier faunas. We are holding the same reservation regarding the precise nature of some of the borings here assigned to sponges of this type because of want of full comparative evidence, but the assignment is based on comparisons of size and mode of growth as

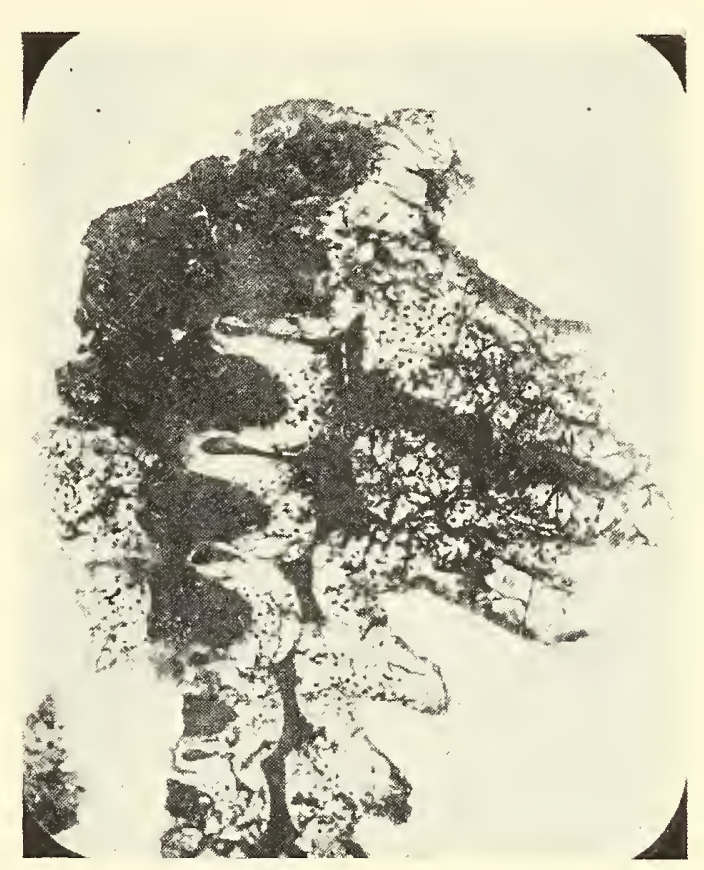

Fig. 69. Boring algae in the test of the trilobite Odontocephalus selemurus (Devonian). $\mathrm{x} \mathbf{2 5}$. between the microscopic tubules of the algae and the large regular tubes of the worms. ${ }^{2}$ In a previous discussion of such perforating organisms ${ }^{3}$ we instituted the generic designation Clionolithes for a group which was based on the form described by $\mathrm{McCoy}^{4}$ from

1 See T. S. Collins. "Some Perforating and Other Algae on Fresh Water Shells''; Erythea, v. 5, p. 95. 1897.

2 Comparison with the tubules of living perforating sponges may be made by reference to the work of Emile Topsent in the Archives de Zoologie Experimentale, 2 d ser., v. 5 bis, 1887, 1891; 4th ser., v. 7, 1907.

3 " Dependent Life."

4"'British Paleozoic Fossils,'” 1855, p. 260, pl. 13, fig. 1, 1 a. 


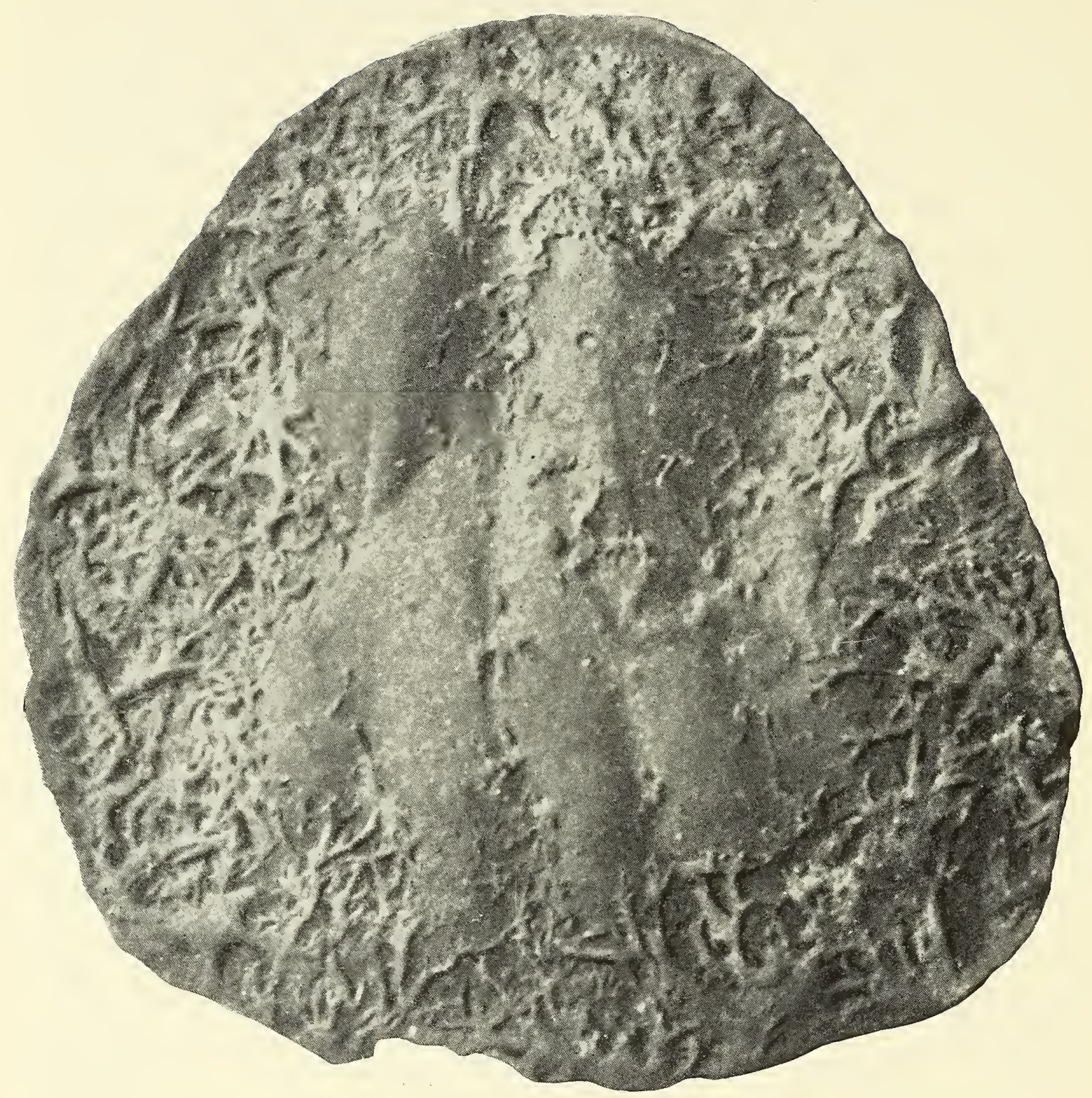

Fig. 70. Clionolithes radicans. Etched specimen of an old shell of the brachiopod Dalmanella superstes of the Chemung shales (Upper Devonian), with a multitude of irregularly branching borings riddling the shell and apparently starting inward from the shell margin. $\mathrm{x} 10$. 
the Silurian as Vioa prisca and which was made by us to include not only tubes of that type, that is, straight subclavate fillings, but also very much smaller, much more intricate, arborescent or vagrant tubules. It is evident to us now that only the latter can be assigned to the sponges and that hence our name Clionolithes, devised to suggest relationship to sponges, is applicable only to this division. It is proposed to retain the name for that group, even though this may not be in precise accord with proper no-

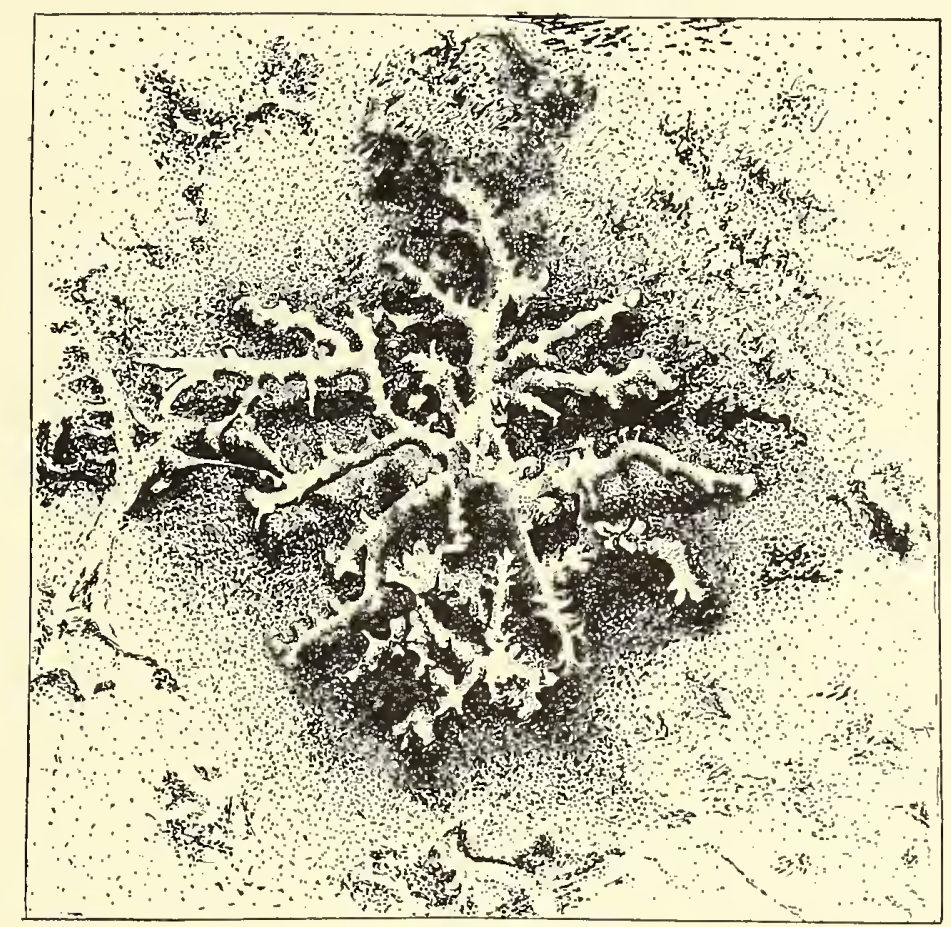

71

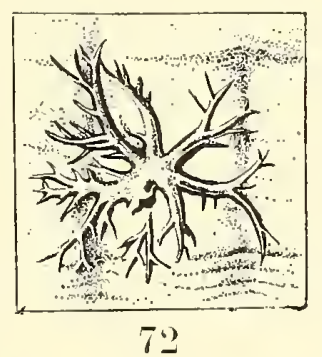

Fig. 71. Etching of a tube cluster of Clionolithes rarlicans in the shell substance of the brachiopod Leptostrophia magnifica. From an enlarged photograph. x 64. Grande Grève limestone (Lower Devonian).

Fig. 72. The same in a shell of Atrypa reticularis from the Chemung sandstone (Upper Devonian). 
menclatorial procedure. The Vioa prisca and its type being undoubtedly worm borings must take a more appropriate designation.

We are referring to Clionolithes, the form C. radicans, which enters brachiopod shells by a simple perforation and once within the shell substance produces a radiate and arborescent or root-shaped colony. Shells are often quite riddled by these colonies, which may maintain individual independence, no matter how numerous, though at times in a thick shell, galleries may so overlie one another as to appear massed or felted. It is this form of sponge which may be taken as the type of the genus.

Clionolithes palmatus, which has been found only in the soft shales of the Portage group (Upper Devonian), presents a somewhat different aspect from $C$. radicans in its broad, sparsely branched or palmate tunnels.

Clionolithes reptans is a filamentous and vagrant tube tunneling just beneath the surface of the host-shell. It is common in brachiopod shells of the Lower Devonian and it is assigned to the sponges because there seems no better present interpretation of it.

Of entirely different type and of much greater size is a perforating sponge which we observe in the Middle Devonian Stromatoporas of Iowa. In this there is a large spherical central body from which stout cylindrical arms radiate into the coral substance. The formation of the tunneling appears to begin with the gradual burial of the round centrum with its branches and the subsequent excavation of additional tunnels by later outgrowths of the colony. These sponges have been found both as depressions at the surface of the coral and as completely buried bodies within the coral substance and revealed only by cutting.

This parasitic sponge we shall designate Topsentia devonica.

Worms. The boring worms of the existing fauna have 


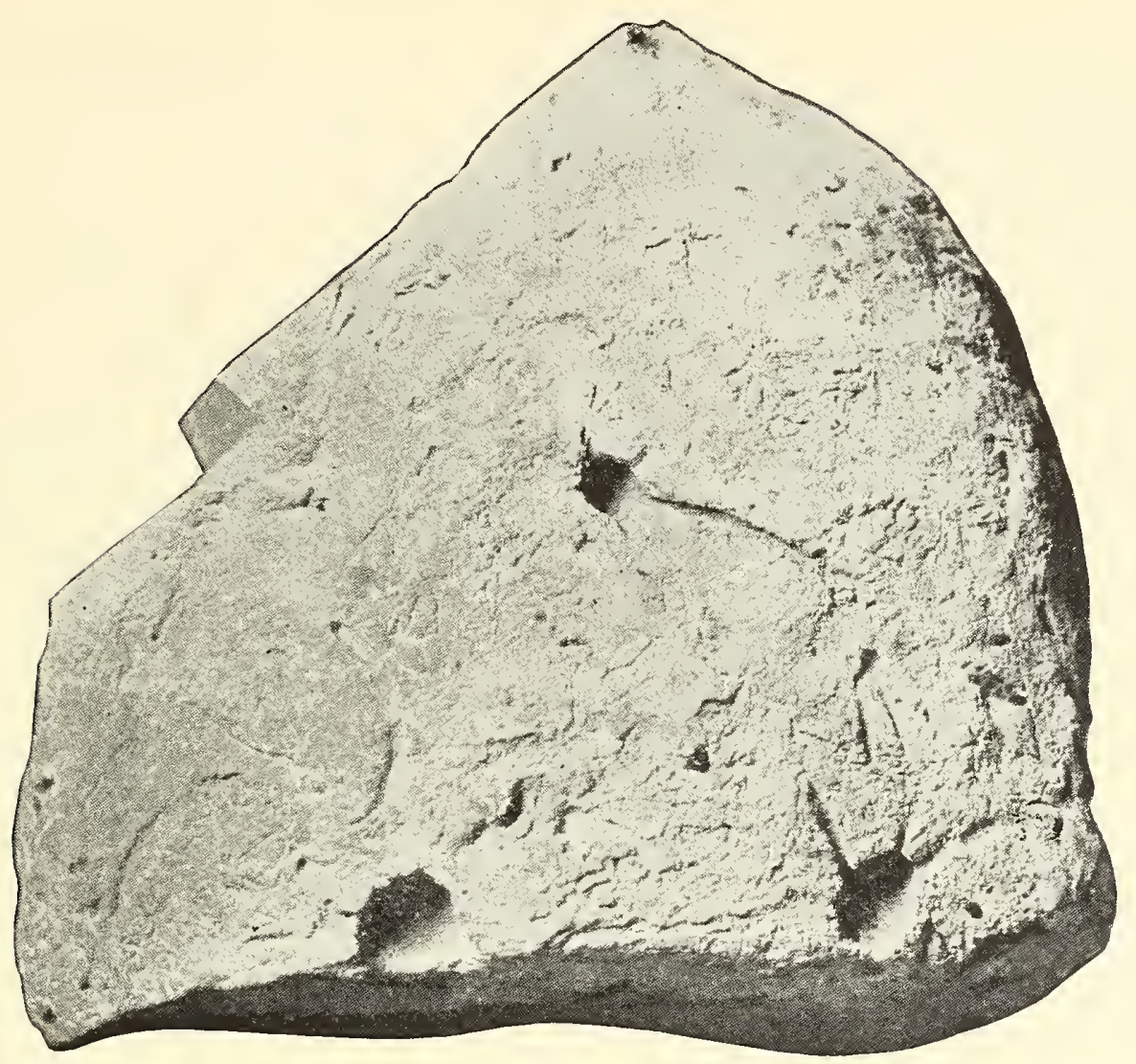

Fig. 73. The surface of a Stromatopora from which three individuals of Topsentia, a boring sponge, have been removed by weathering.

been especially studied by E. Ray Lankester ${ }^{1}$ and W. C. McIntosh ${ }^{2}$ who have described the habits of such genera as Sabella, Leucodore, Dodecaceria, whose individuals abundantly penetrate corallines, corals, limestone and other rocks. Sabella saxicava Quatrefages makes a usually straight tube, but these are often deflected or curved, sometimes looped so that both extremities protrude. This loop shape is a habit common to a number of worms which bury themselves in soft mud, and is familiar in the sediments of the Paleozoic rocks. Such U-shaped burrows into the sea bottom have been recorded in rocks as old as the early Ordovician. ${ }^{3}$ The same shape characterizes some of the living worms which construct agglutinated tubes. Such tubes as

1 Annals and Mag. of Nat. Hist., April, 1868, p. 233, pl. 11.

2 Ditto, October, 1868, p. 276, pl. 18, 20. See also W. Blaxland Benham in Cambridge Natural History, 2, "Polychaet Worms,'” p. 287.

a See Hayes, op. cit. 

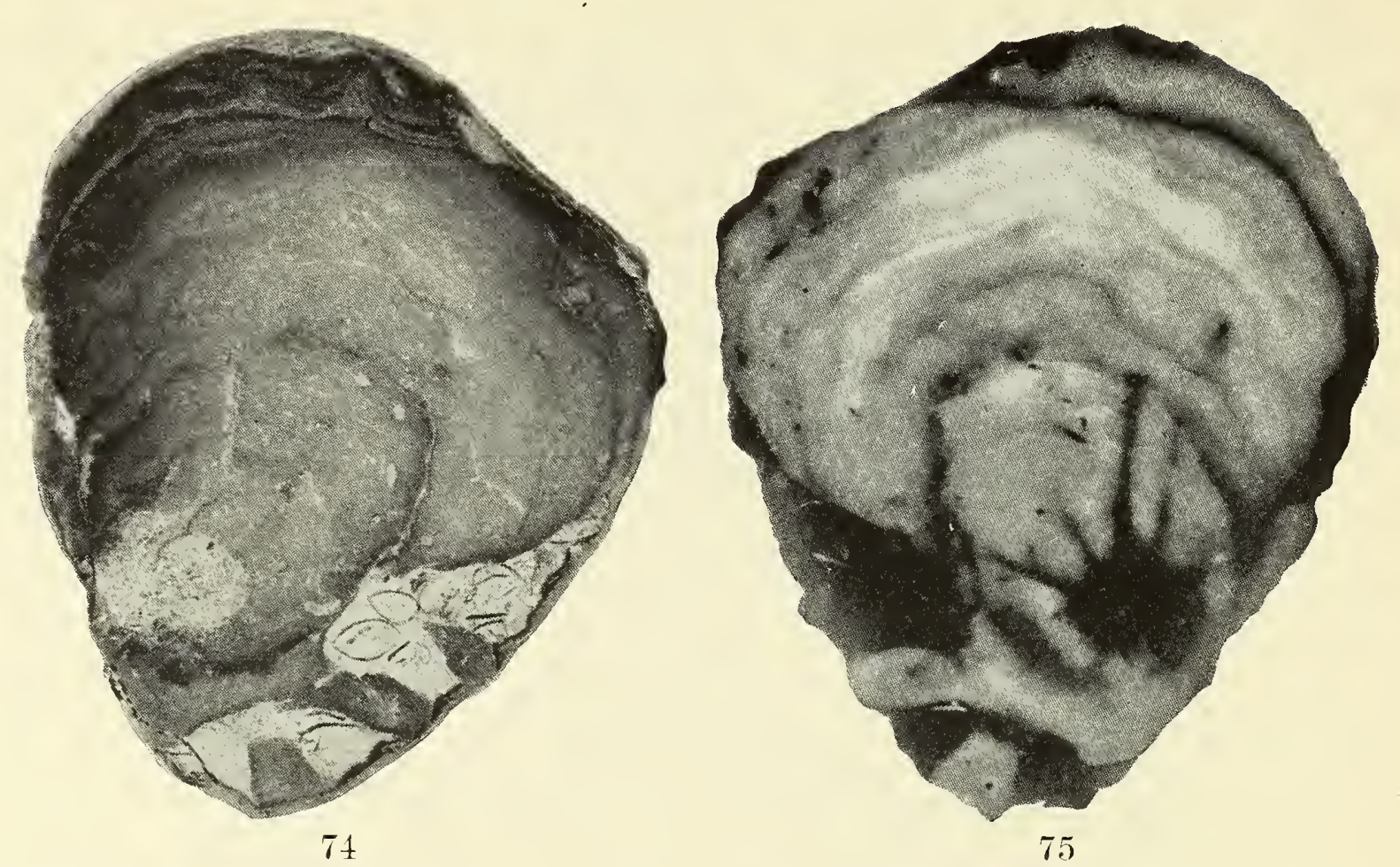

Figs. 74, 75. The perforating sponge Topsentia deronica in a Middle Devonian Stromatopora (Iowa). Fig. 74 is a polished section; Fig. 75 shows the embedded sponge by transmitted light.

these made by the worms are in contrast to the perforating tubes described because of their usual simplicity and their greater size, and among the fossil occurrences these features lead to comparatively easy and safe recognition.

These simple worm-borings are found in many sorts of solid calcareous organic masses in the Paleozoic rocks. While we find in the Ordovician worms growing concurrently with solid corals or coralloid bryozoa, like Prasopora, there is no present evidence of perforating worms boring into such masses and more specially into molluscan and other heavy shells, until late in the Silurian, from which date they acquire greater abundance and in the Devonian faunas become widespread. As the evidence now stands they were rife in the early Devonian everywhere, even in the austral faunas of this period which are in many respects widely distinct from the contemporary faunas of the north. ${ }^{1}$

1 See Clarke: 'Fosseis Devonianos.' 
In the later stages of the Devonian they seem less common and become increasingly so through the rest of Paleozoic time. It would appear that the early Devonian was the climacteric period of these Sabella-like boring worms.

In seeking a designation for these tubes and burrows, we have noted the fact that they were described by McCoy under the name Vioa prisca from a Silurian mollusk. Vioa being an existing genus of boring sponges, and as we are convinced that such tubes as were indicated by McCoy are referable to the worms, a more appropriate name is required and we propose to apply to all of them the designation Paleosabella prisca (McCoy) disregarding differences in size, which are often obvious, and of curvature, which are slight. We give abundant illustration of these occurrences and in the explanations to them point out features of special interest.

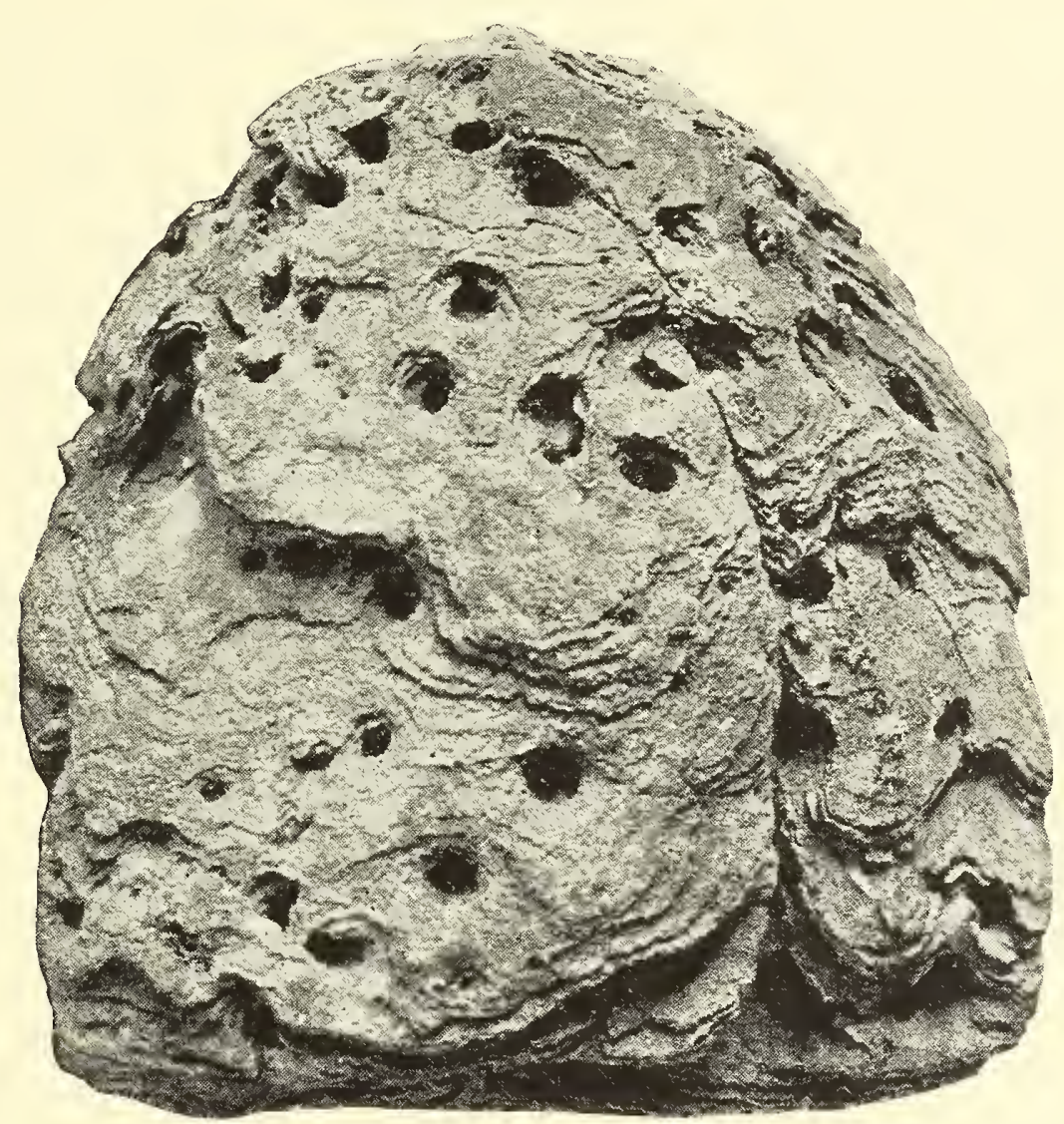

Fig. 76. A stromatoporoid coral from the Niagara group (Silurian) of Hamilton, Ont., with weathered holes of boring worms or sponges. 
To a flattened tube with raised edges, giving the suggestion of a distinct loop with the branches connected by a thin diaphragm, we have on a previous occasion applied the name Caulostrepsis taeniola. So far as our present knowledge goes this has been seen only in strophomenoid brachiopods from the Lower Devonian of the Rhineland.

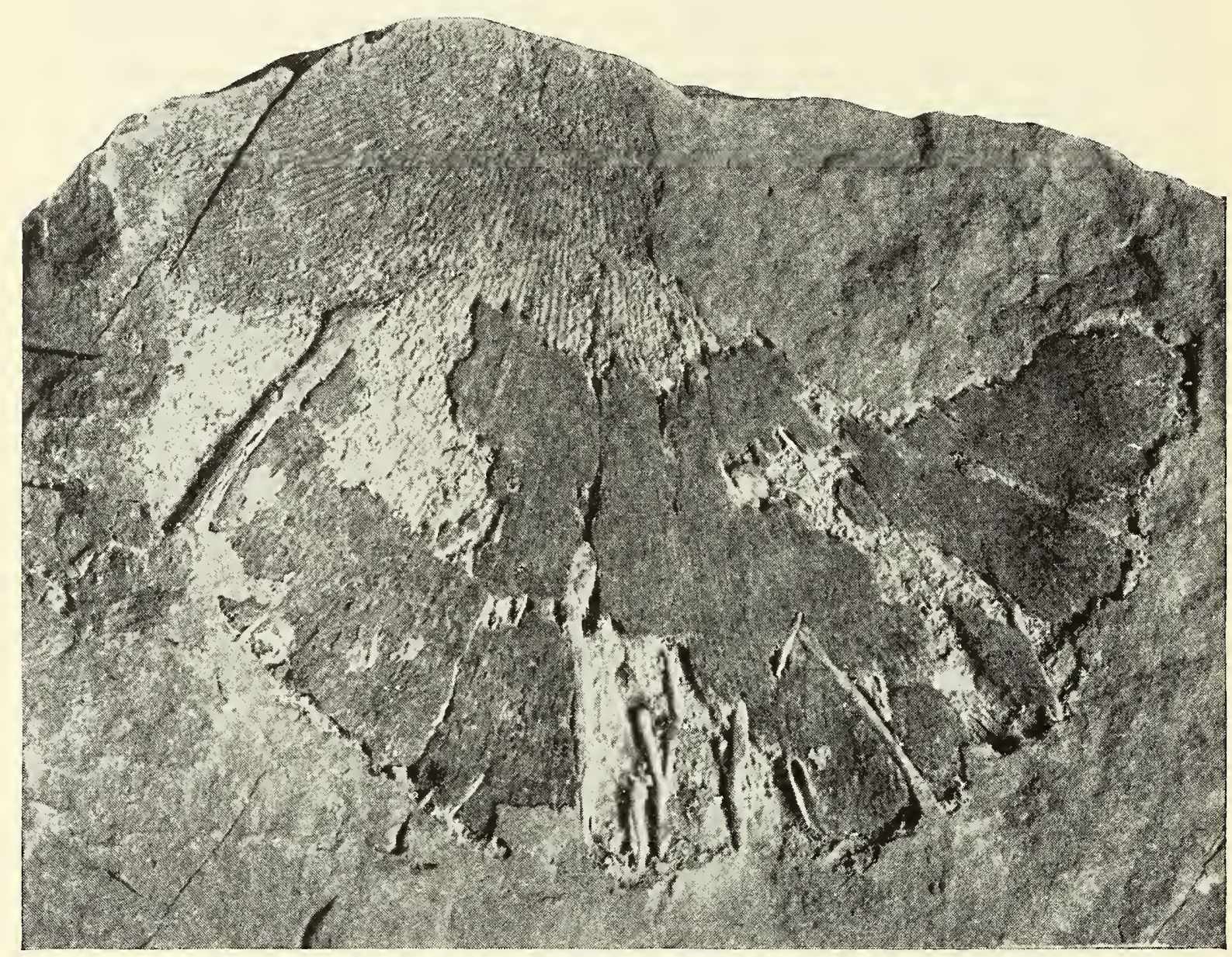

Fig. 77. Palaeosabella prisca in a valve of the brachiopod Leptostrophia. From the Grande Grève limestone (Lower Devonian); enlarged.

Finally, it is worthy of note that the host-shells receive these boring worms in various ways. Sometimes the parasite starts at one surface and bores straight across to and through the other surface. Again a number of worms may commence their attacks simultaneously at the growing edge of the shell and while they bore parallel to, and within the shell surfaces, the shell grows on outward beyond the circle 

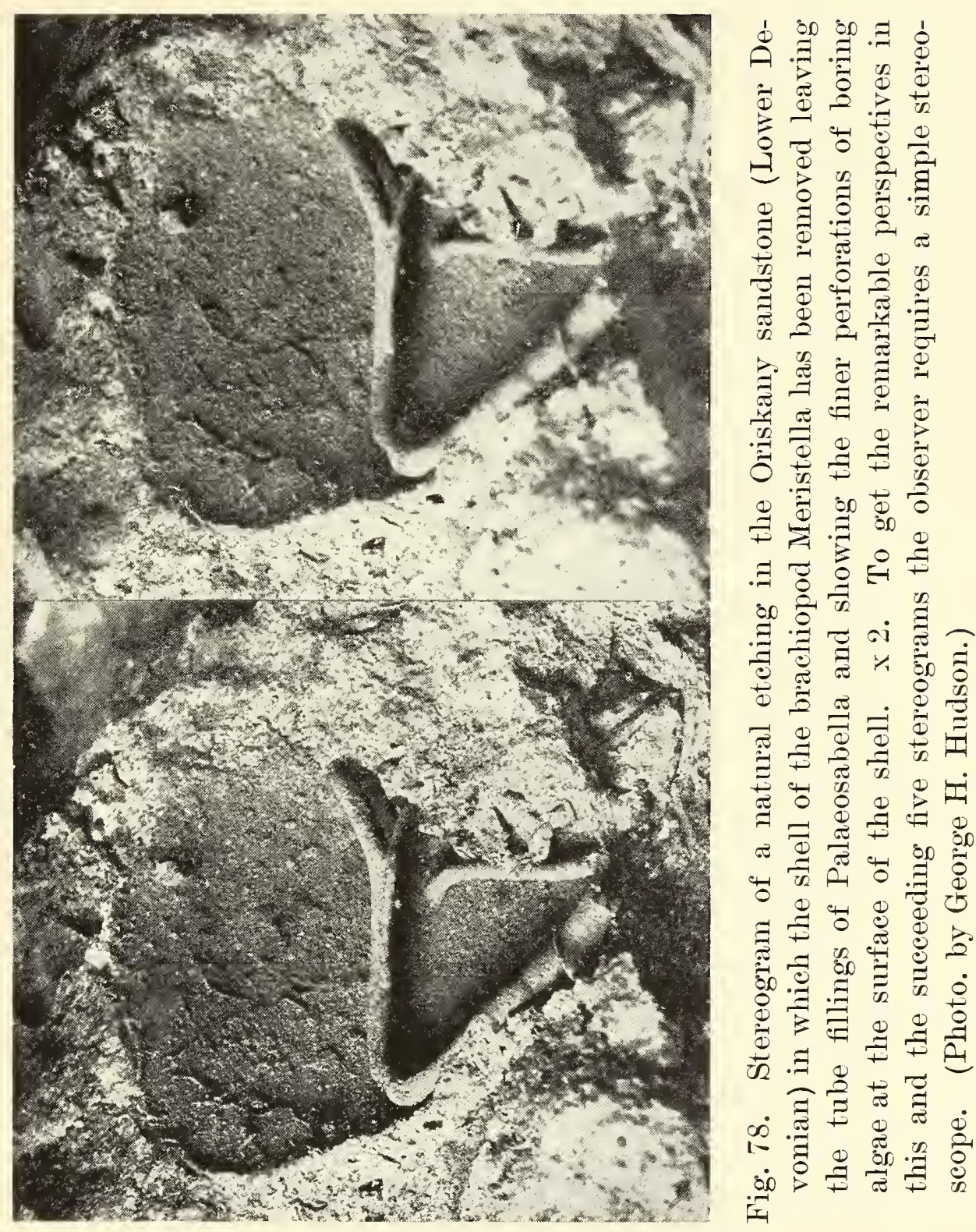


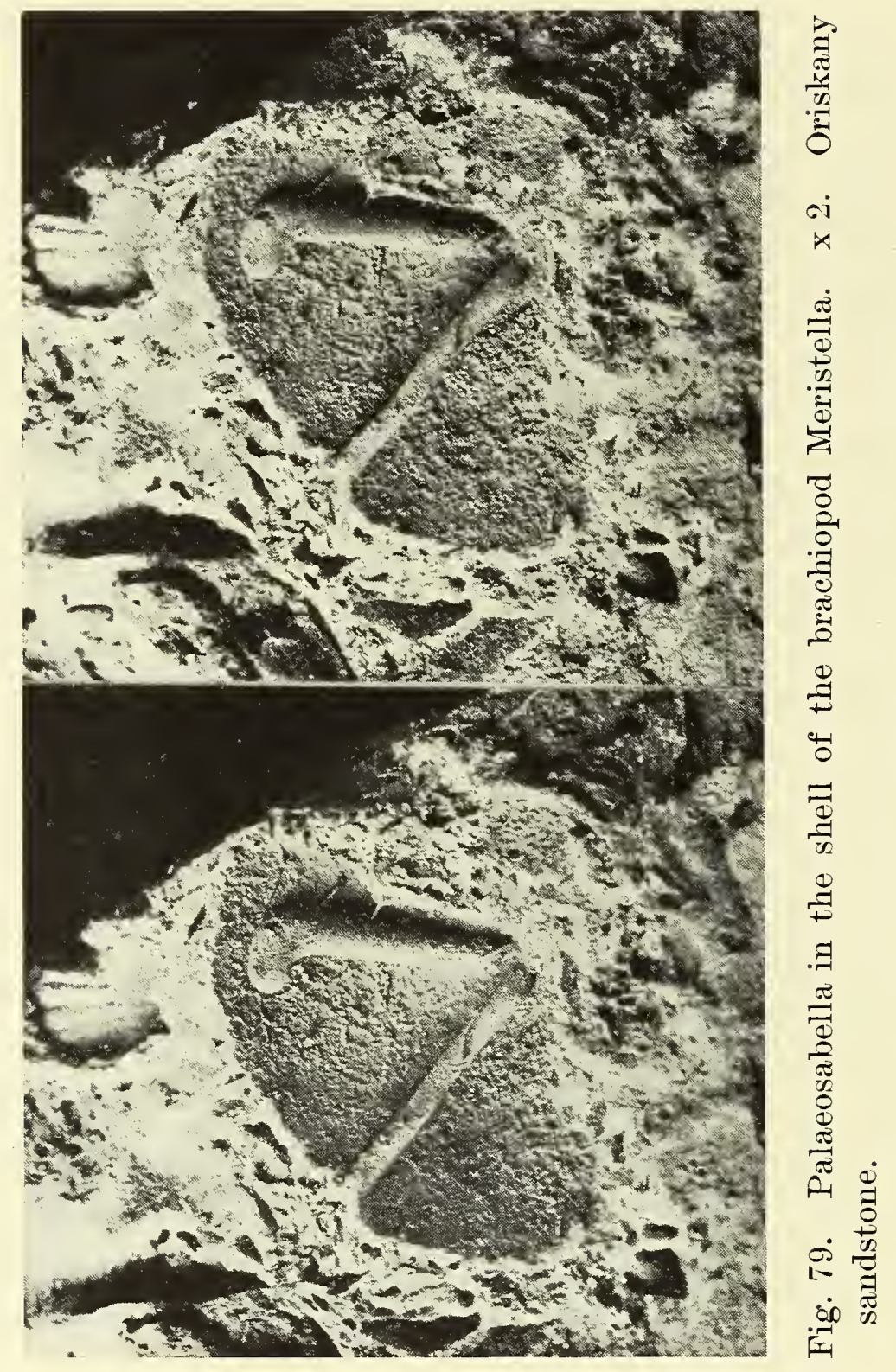




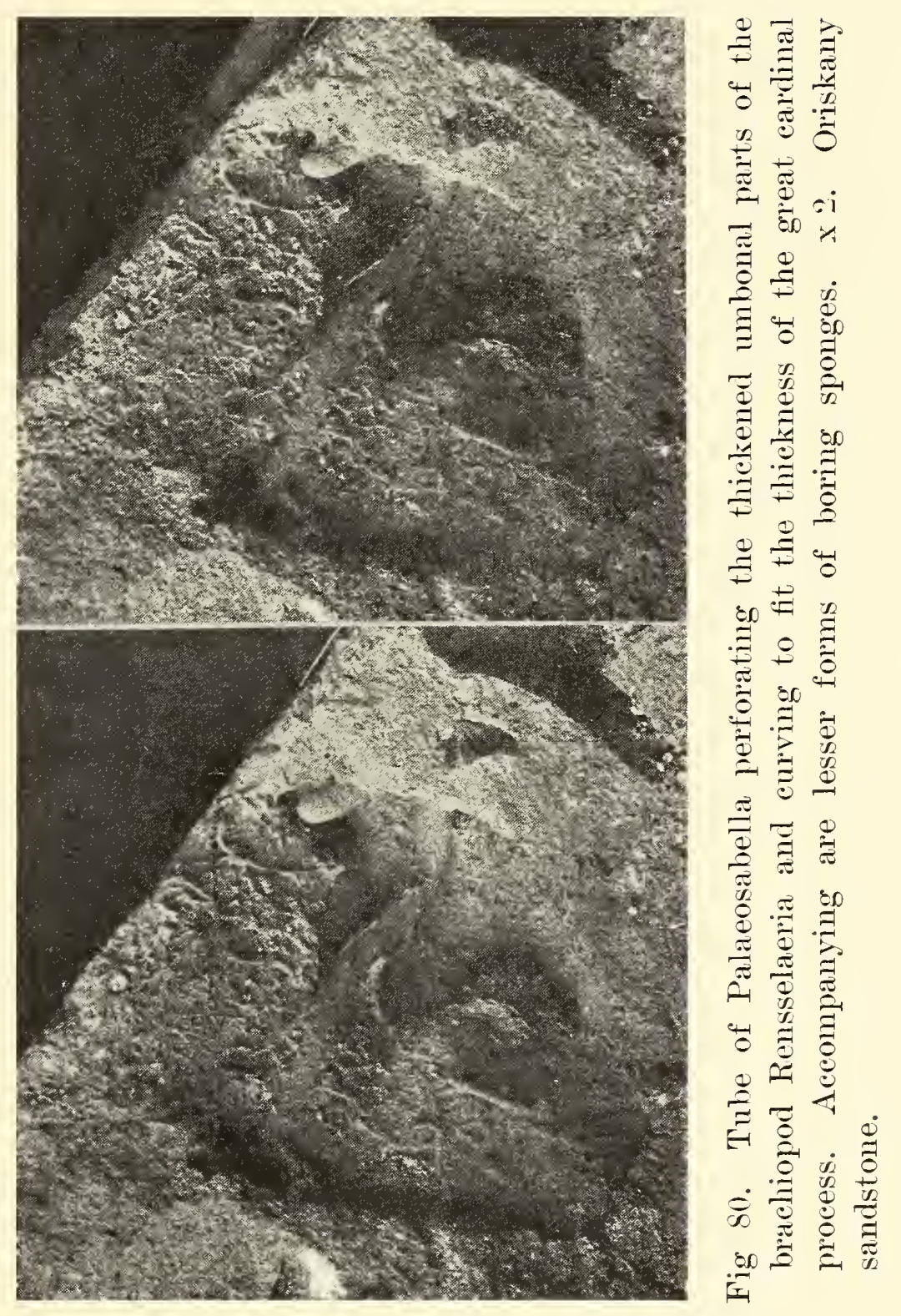









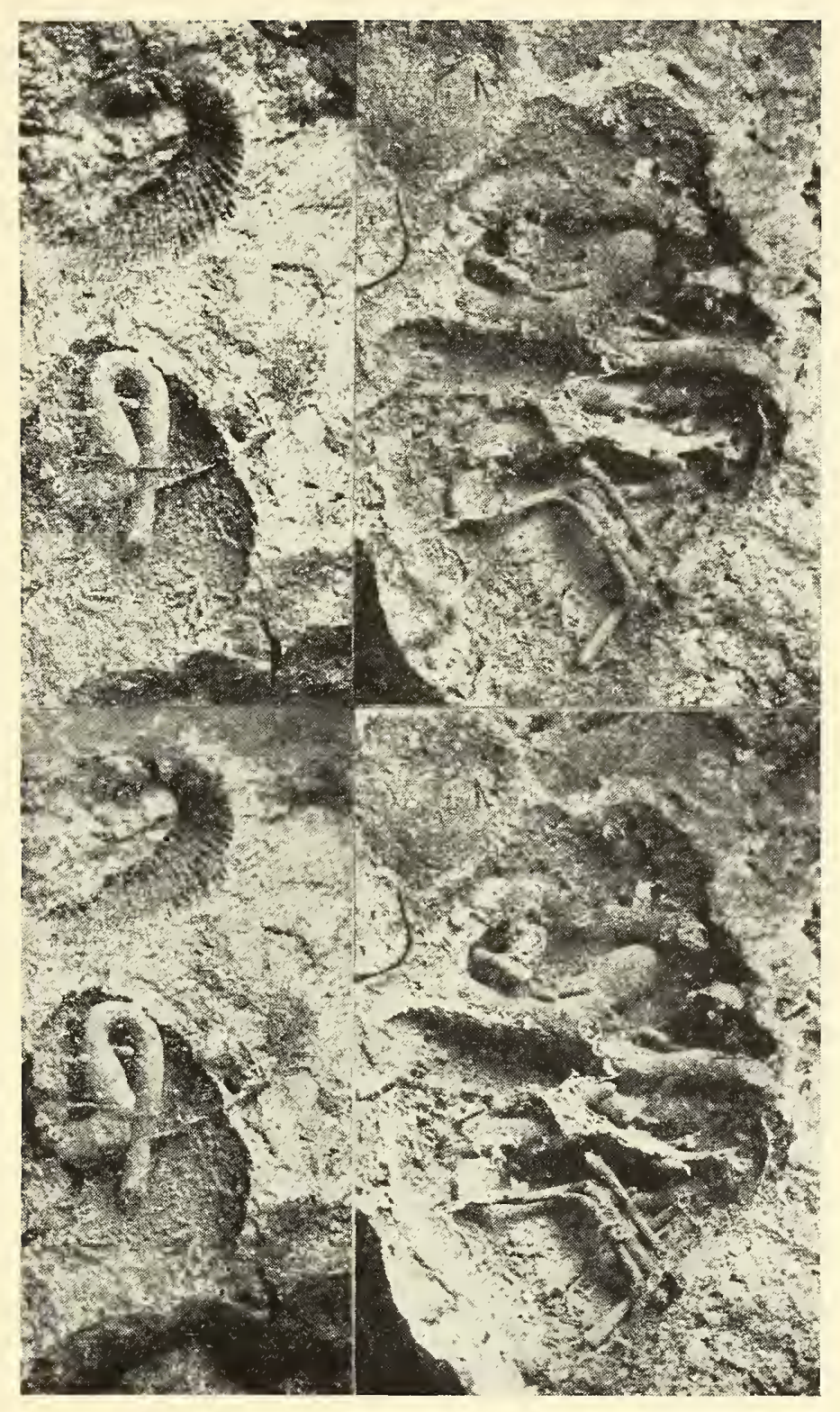

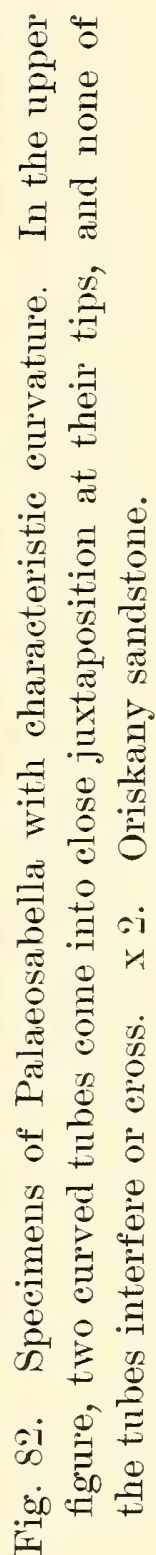




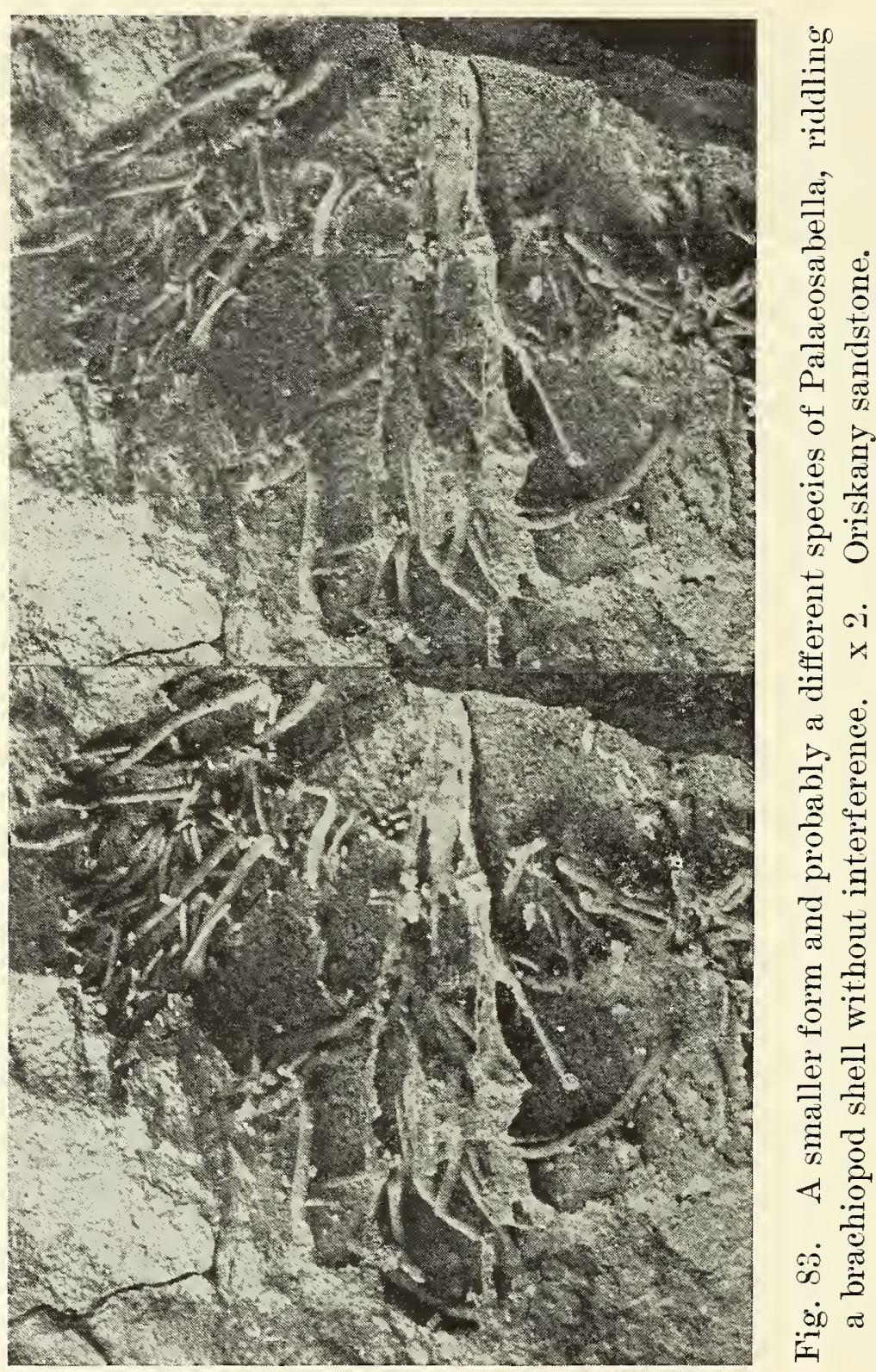




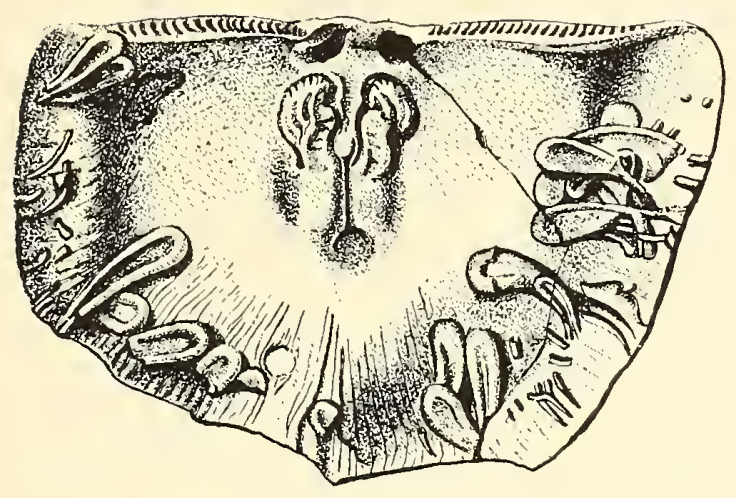

a

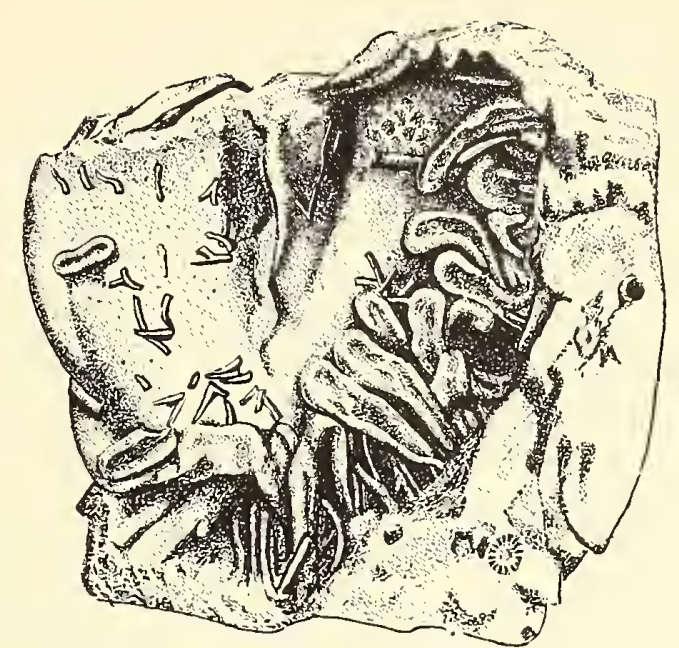

b

Fig. 84. Caulostrepsis taeniola growing in the shell of the brachiopod Stropheodonta from the Coblentzian (Lower Devonian) of Seifen. The margins of the brachiopod valves have been entered on all sides simultaneously by these borers which have made loop-shaped tubes joined by a median eavity. Together with these are simple tubes of Palaeosabella.

of their entrance. Often the tubes adapt themselves to the thickening or thinning valves, taking advantage of the former to recurve or loop, and compelled by the latter to flatten down. The tendency to make a hook or loop, or to take on the U-shape, is shown in many cases and the development of a clavate form at the blind end is frequent and characteristic. Most interesting beyond these features is the fact

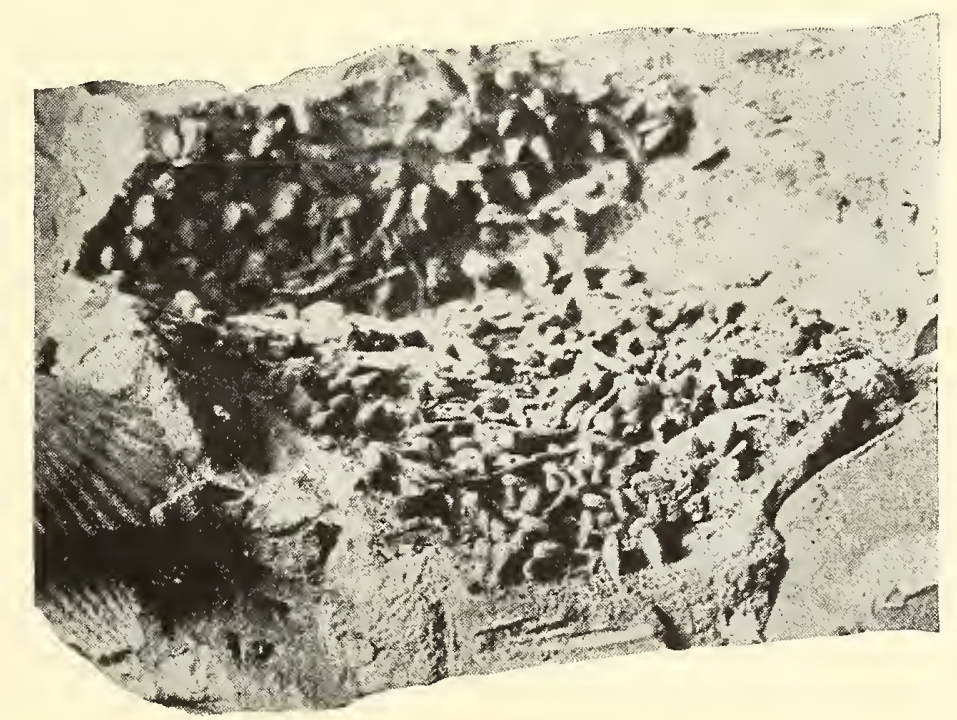

Fig. 85. Cast of pouch-shaped (algal?) borings extending in from the surface of a brachiopod shell. $\mathrm{x} 4$. Oriskany sandstone (Lower Devonian). 


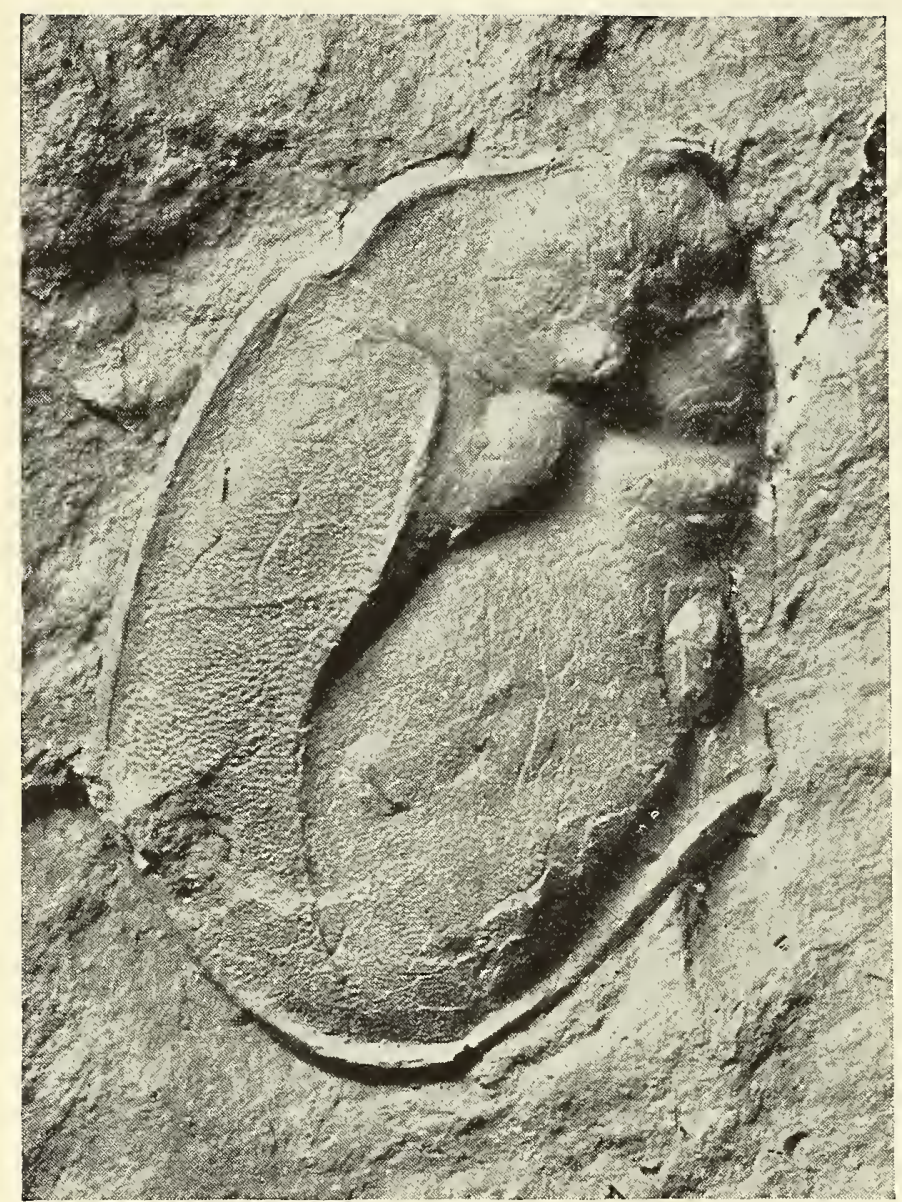

86

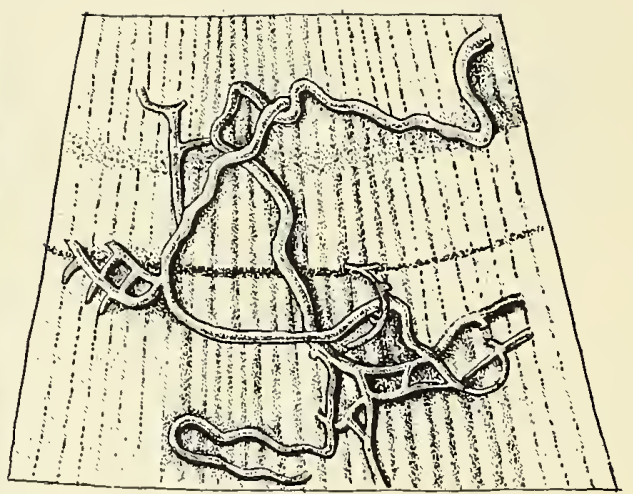

87

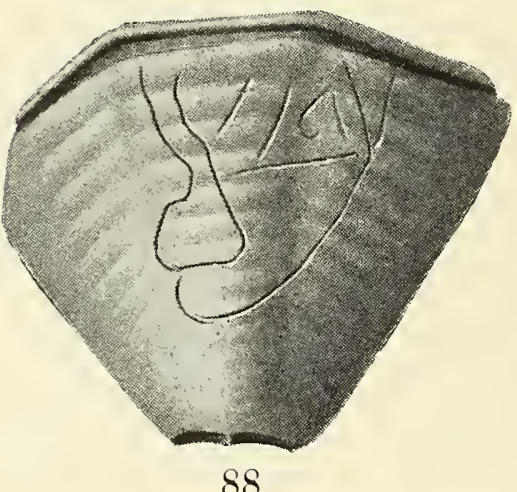

88

Fig. 86. One valve of the phyllopod erustacean Echinocaris punctata with marks of Clionolithes borings among the surface ornament. Hamilton group (Middle Devonian).

Fig. 87. Clionolithes reptans; diffuse tubules in the shell substance of the brachiopod Leptostrophia. x 20. Oriskany (Lower Devonian).

Fig. 88. The pygidium of the trilobite Homalonotus Dekayi exposing by weathering the tubules of a similar species; natural size. Hamilton group (Middle Devonian). 


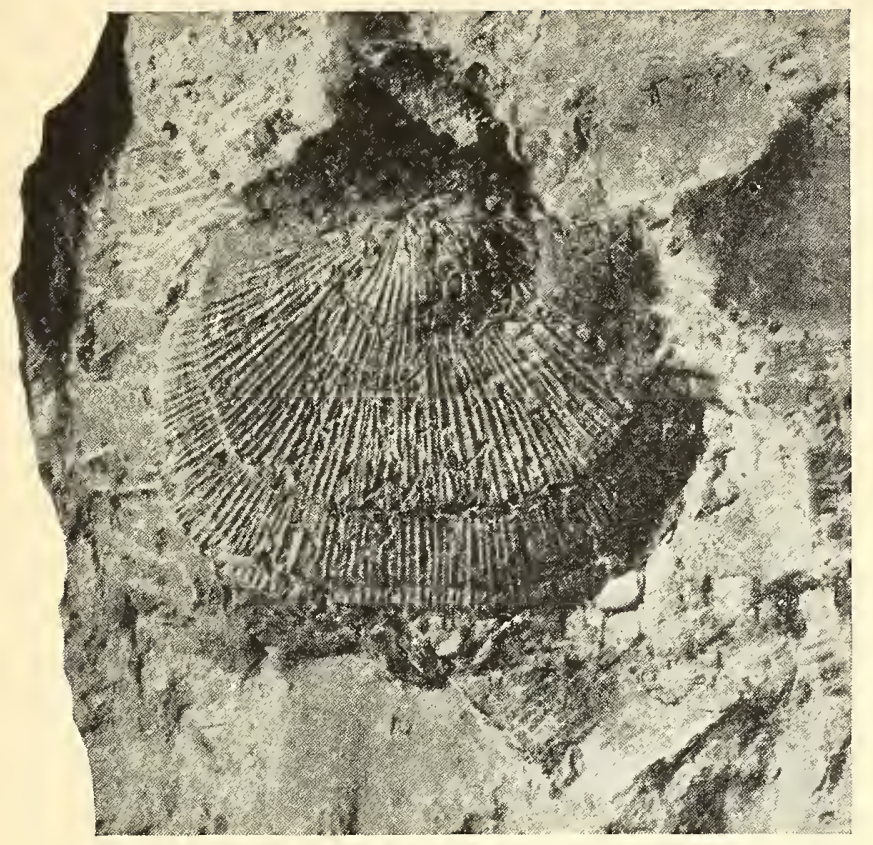

90

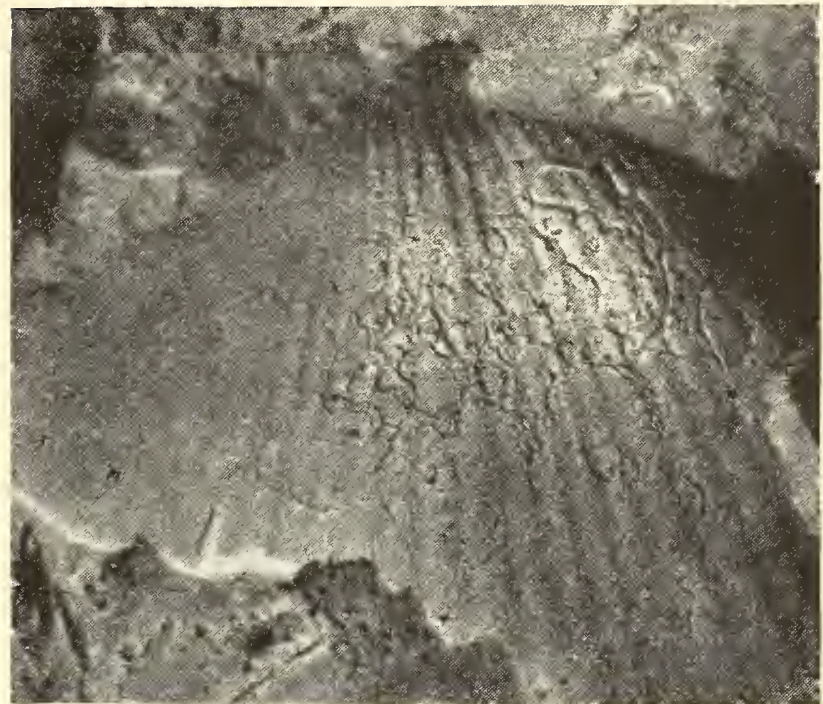

89

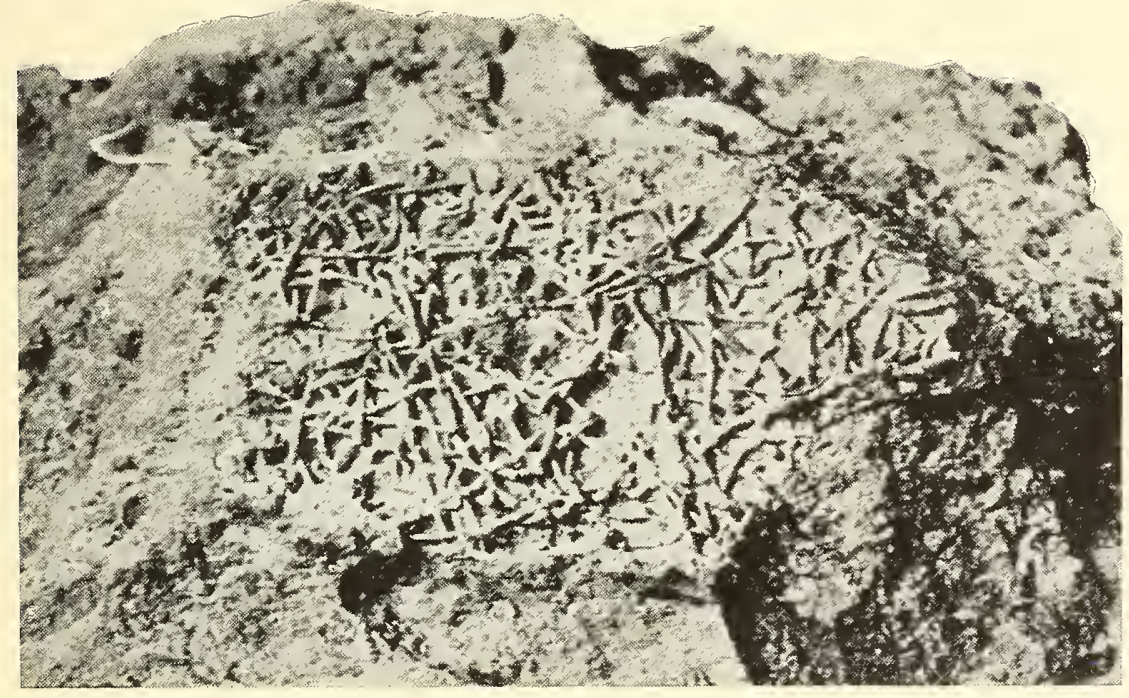

91
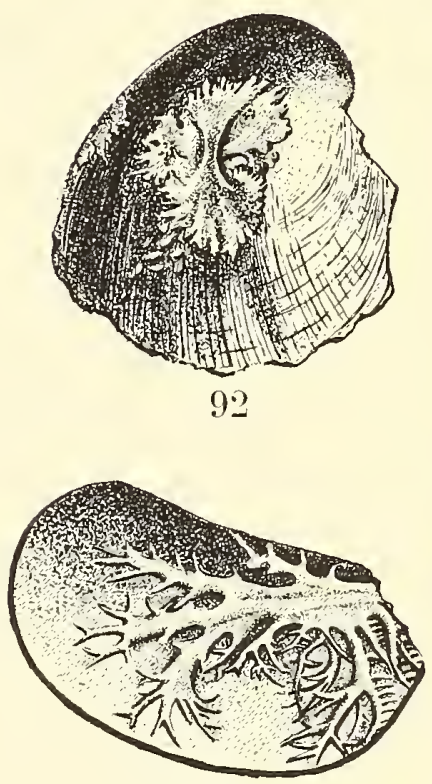

93

Fig. 89. Clionolithes reptans in the shell substance of Spirifer aremosus. Oriskany sandstone (Lower Devonian).

Fig. 90. A shell of the brachiopod Streptorhynchus with borings of Clionolithes camna Price. From the Pottsville series (Mississippian).

Fig. 91. Clionolithes cama Price. Conemaugh series (Mississippian). Much enlarged.

Fig. 92. Clionolithes palmatus in the shell substance of the bivalve Loxopteria dispar from the Portage beds (Upper Devonian).

Fig. 93. A similar palmate boring in a gastropod shell, Loxonema, from the same locality. 
Fig. 94. Palaeosabella prisca (MeCoy). Copy of the original figure.

Fig. 95. The same in the shell of the brachiopor Spirifer from the Chemung group (Upper Devonian).

Fig. 96. Similar clavate tubes in the brachiopod Leptostrophia. Oriskany sandstone (Lower Devonian).

Fig. 97. Sketch of Palaeosabella tubes converging from the margin toward the thickened apex of the brachiopod Spirifer.

Fig. 98. A similar sketch to show the bend in the tube where the shell is thickest. Hamilton group (Middle Devonian).

Fig. 99. The bivalve Aviculopecten with borings all beginning at a definite growth-stage of the shell, outside of which the shell is regular, indicating that the mollusk was alive when the borings were started and continued to live while they were making. Chemung group (Upper Devonian).

Fig. 100. The sponge here started in the thickened apical substance of the shell of a brachiopod (Leptostrophia) and as it entered the thinner part of the shell was forced to take on a flattened form. At the inner end it shows a tendency to divide.

Fig. 101. A hook-shaped boring in the cast of a brachiopod. Oriskany sandstone (Lower Devonian).

Fig. 102. A set of clavate borings in the brachiopod Leptocoelia. Oriskany sandstone.

Fig. 103. A series of these tubes beginning at the margin of the discinoid brachiopod Orbiculoidea. Lower Devonian. Sao Paulo, Brazil. 


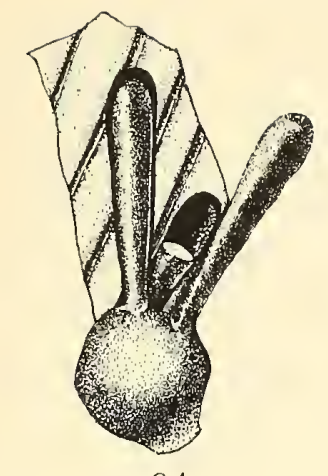

94

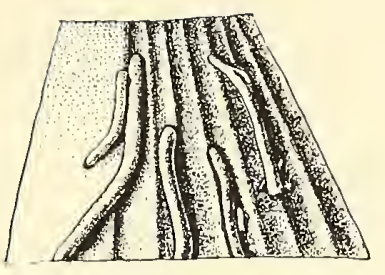

95

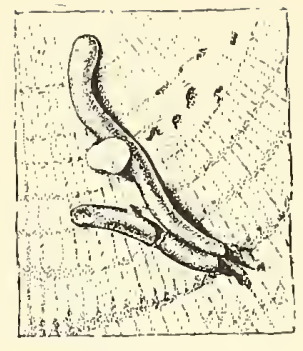

96

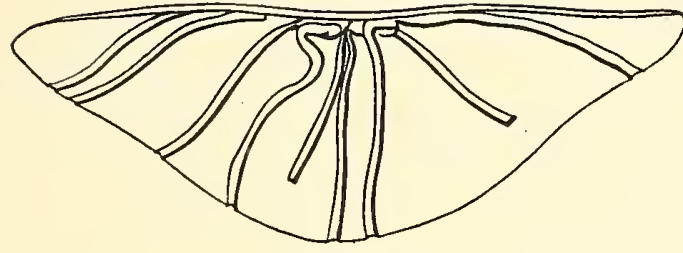

97
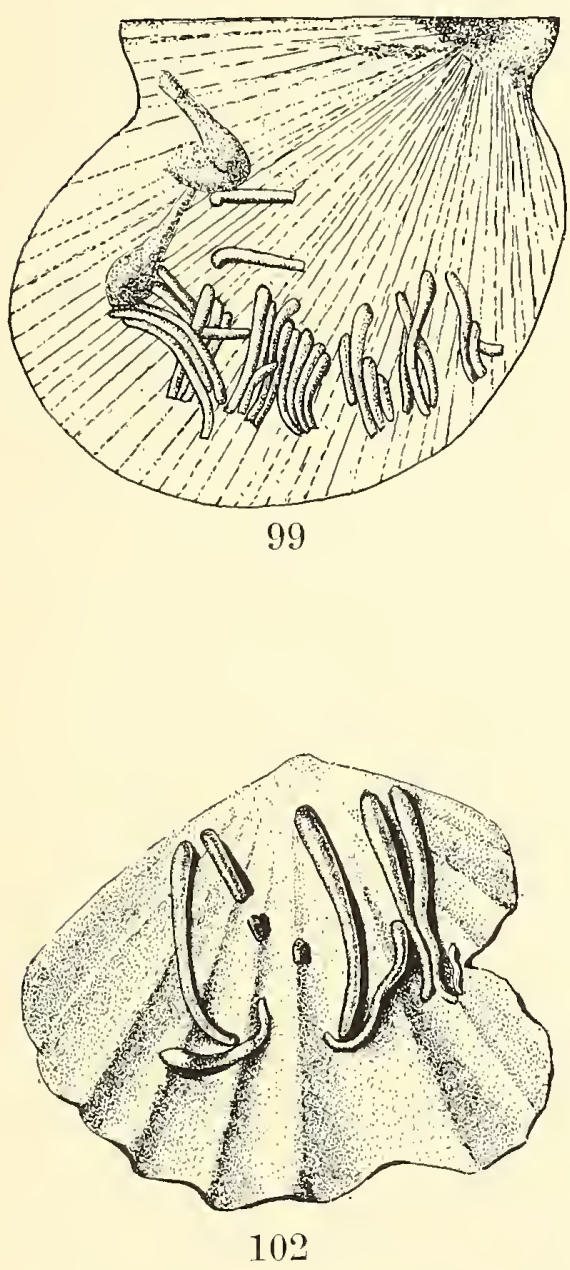
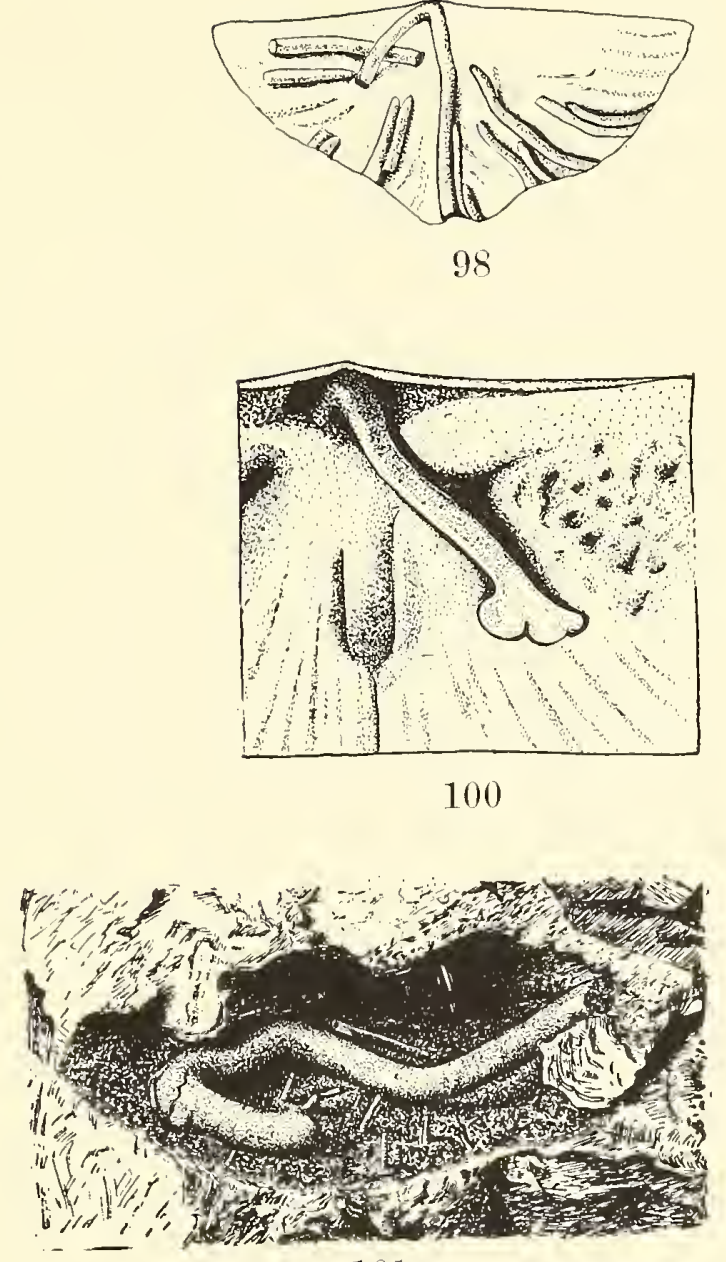

101

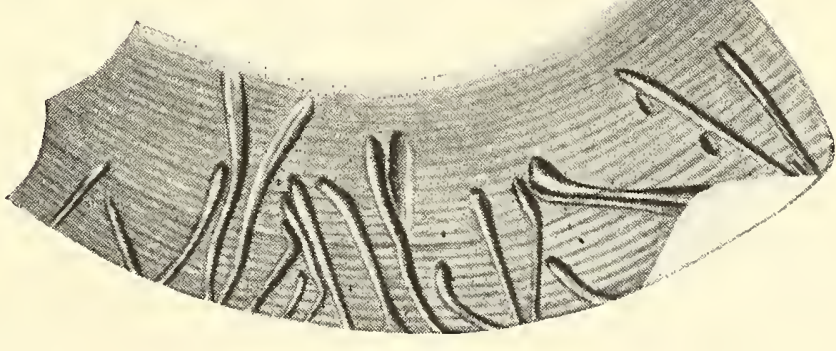

103 
that in host-shells which have been well riddled by these tubes and where the channels are closely crowded together in numbers, there is very rarely any evidence that one crosses another or even touches its neighbors.

\section{THE DISTINCTION BETWEEN PROTOZOAN AND METAZOAN PARASITISM}

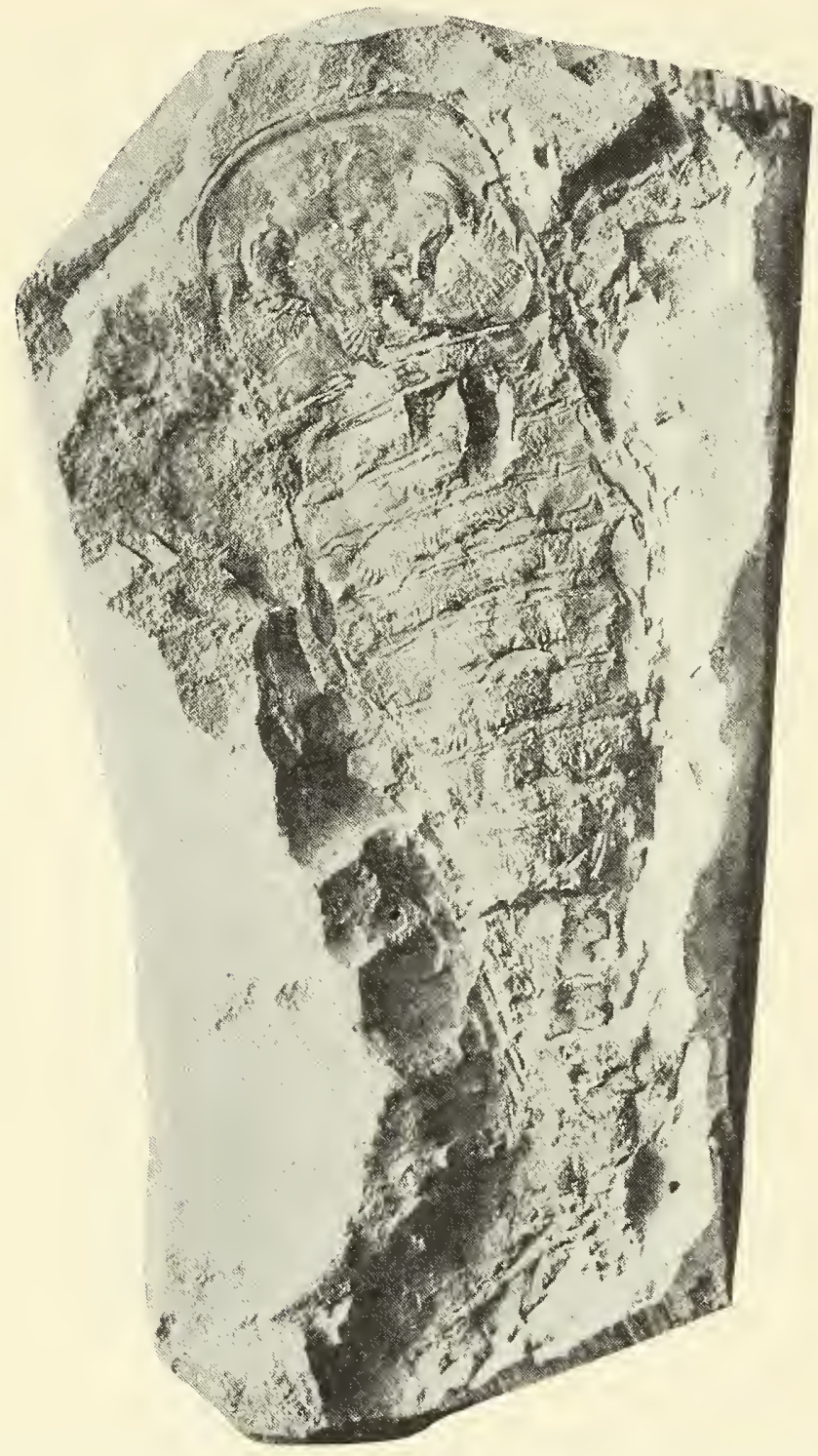

Fig. 104. The Silurian scorpioid erustacean Eurypterus fischeri from Rootzikull, Russia, showing an overgrowth of agglomerated tubules which seem to have spread from joint to joint but clear all articulating surfaces; a symbiotic and perhaps parasitic growth whose nature is not fully understood.

Modern epidemiology and germ pathology which are founded on the recognition of the play of the protozoan or protophytic parasite in disturbing the health of human beings, have at times indulged in too hasty expression as to the prevalence of protoplastic germ disease throughout the history of life on the earth. Germ infection, in the sense of protoplastic protozoan and protophytic adjustment, is universal; it enters into every phase of life and into every individual of the animal and plant world. That is, all life from highest to lowest is shot through with conditions of disorder resulting from such parasitic adjustments. There is no exception. The picture 
is that of a universal struggle to maintain existence at the cost of some other's normal physiology. It is the unremitting battle of the invisible. The fight is not hidden away from eyes that are trained to see, and its victims lie dead on every field. It is a war whose harvest, surpassing computation, is the only salvation of a crowding world.

But it is easy to forget that the picture has another side and that the attacks of the protozoan army and all the race of unicellular parasites are not by any means malign in their results. It is vice rather than virtue that ever challenges widest attention. Probably more of these adjustments are benign and helpful to the host than are harmful, and there are as many "good" germs as "bad" ones. It is reasonable that the student of germ pathology should be so profoundly impressed with the mischievous invasions as to understate the helpful activities, and thus be led to such a conviction as that expressed by Eccles, "The Path of Evolution is the Path of Past Disease." The history of such protozoan adjustments is not properly within the present scope of our subject, though we must look at certain paleontologic records which have been interpreted as devastating results of widespread germ infection.
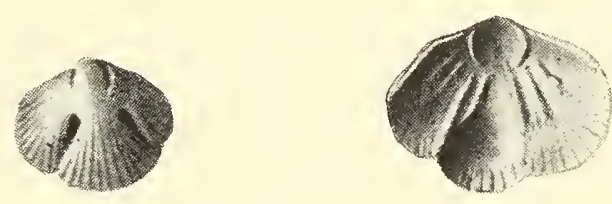

Fig. 105. Valves of the brachiopod Dalmanella testudimaria from the Lorraine shale (Upper Ordovician), in which disease in, or injury to, the mantle of the shell has produced irregular growth.

It is not to be wondered that several writers, Metchnikoff and Eccles among them, who have had under their eyes the universality of parasitism in existing nature, should be very positive in their expressed inferences that destructive pathologic parasitism has continued for vast ages. The statement is undoubtedly deductively correct within certain 
limitations of time. But we have little except inference to build on in applying this statement to those early periods of geological history in which various types of life were establishing themselves and with which we have been especially dealing.

Two reasons restrain us from attempting to ascribe such high influence to microörganic disease in the early life periods of the earth:

1. Inadequate records.

2. Protozoan parasitism functions essentially as a chemical attack upon the tissue and proteid contents of the cell of the host for purposes of nutrition, and results in injury to such tissue by exudation of active poisons. In metazoan parasitism the injury thus caused, if any, and the adjustment in any cases, are mechanical and due to the functional mechanism of the parasite.

The essential conception of germ disease is the invasion of the cell by another cell, in which the invader strikes right at the heart of the host by the attack upon the molecular constituents of the protein, inclusive of the chromosomes which are the recognized carriers of the traits which we characterize as individuality and heredity. It is, in other words, the attack of the individual cell on the individual cell, in which the invaded cell must rouse itself to its full power of opposition by the development of greater molecular strength and more resistant cell tissue.

Of such procedures we can learn only from the living world.

The conception that the progress of life by evolution is the path which germ disease has permitted and which might have been otherwise if not prevented, would seem to tear to tatters the obvious plans and purposes laid down in the scheme of nature-like a carpet that has been so eaten by moths that the pattern is gone and with it the purpose or the thought of its maker. We therefore emphasize the distinction between protozoan and metazoan parasitism and 
regard this distinction important and essential. It is not easy to ascribe to the former as we now understand it, any other force than a pulsing chemistry. In the parasitic association of metazoans that conception must be wholly put aside; here the association is a mechanical one though governed by a pulsing vitality. It is easy to say that the latter is naturally a derivative of the former, much less easy to show evidence for the assumption. The latter is probably successive in time to the former but we cannot show that it exists because of the former.

The course of protoplastic parasitism is essentially chemical and so when it is really pathologic, chemical neutralization is the accepted practice. But the procedure in destroying the bacillus of tetanus is of an altogether different code from the procedure for the destruction of chigoes, tapeworm or trichina. 'The "attack," or speaking with exactitude, the adjustment of the sporozoan parasite, is, as we have stated, an invasion of the molecular contents of the cell and an absorption of its protein; in the metazoan parasite the attack involves an ablation or readjustment of organs or organized tissue.

\section{Sporozoan and Bacterial Parasitism in Geological History}

There are pretty clear evidences of the activity of epidemic infections in geological history and there are, besides these, occurrences which have suggested such interpretation but which may be open to other construction. We have the word of such botanical specialists as Massee ${ }^{1}$ and Berry that even in Carboniferous times the plant world had become infested with parasitic fungi, a fact which of itself bespeaks a long development leading up to these adjustments.

\footnotetext{
1 Massee speaks of four hundred species of such parasitic Carboniferous fungi.
} 
Many writers on the causes of extinction among the vertebrate races of the past have predicated much of germ infestations. Perhaps no one has more effectively summarized these causes of extinction than Henry Fairfield Osborn. ${ }^{1}$ Any student who seeks suggestive evidence of an intensifying cause of race extinction which is wholly collateral to the imperious control of decline in racial vitality, will be impressed by the facts which have been set out in detail by Professor Osborn. From them, however, we can glean no conclusive deduction that any such attacks from external agencies, however devastating the records show them to be at the present time,-trypanosomiasis, rinderpest, tick fevers, sulla, uncinariasis and other such pathologic expressions which sweep away their victims in epidemics, have ever reached the climax of actual race extinction. Notwithstanding the raids by these agents and the check which they put upon reproduction, still the subject races seem to possess sufficient adaptability and surviving competence to outlive them. It is easy to understand that such might not be the case with a declining stock whose racial vitality is already departing and whose impending extinction might well be accelerated by such invasions. In phases like this it may well be conceded that, as an accessory cause, germ infection has been climacteric.

We shall have, sometime, to estimate the differential effects of such epidemic attacks of protoplastic disease according to, or in terms of, the vital phase of the race attacked; for a race at the summit of its vitality can better resist and fully survive such infestation than in its declining stages. And it goes without further statement that the growing and aspiring race which is reaching forward to its climax would sturdily resist such invasions. Finally, we may add that the discovery in the Tertiary rocks, of species of the tsetse fly whose present-day descendants are carriers

1 American Naturalist, Nov. and Dec., 1906. Lull, Lueas, Williston and Moodie have also, among others, written interestingly on this theme. 
of the trypanosomes of the deadly sleeping sickness, must not be too quickly interpreted as evidence of the same infestation in Tertiary times. It may be so, of course, but the ease and quick change of adjustment, known to every student of the lower organisms, must invoke caution in such interpretations.

In connection with these thoughts we naturally revert to Walcott's important determination of a Micrococcus from the Precambrian rocks-the earliest form of life and the simplest; yet, in the opinion of the most competent, indistinguishable from still living forms of bacteria. We touch this delectable morsel of fact with caution-it stands as yet alone and independent, but it opens the door to a new, vast and inviting field of microscopic research among the older rocks, which affords the promise of much light upon the history of bacterial functions.

\section{SUMMARY AND CONCLUSIONS}

Out of the facts and reflections here assembled it would seem that these conclusions regarding the beginnings and the progress of symbiotic dependence may safely be drawn.

1. Symbiosis was inaugurated very early in the history of life. It visibly existed in the Ordovician fauna and inferentially must have been present in the Cambrian ages.

2. In these early stages of life its occurrence must have been rare and sporadic, even if we grant that it prevailed in the soft-bodied animals or plants that have left no fossil remains.

3. Such combinations, in their inception, were innocuous and took on the primary expressions of commensalism or mutualism; partnerships which were in most instances undoubtedly of mutual helpfulness at the start, whatever the risk to progress. In the most notable of these ancient combinations, in which the highly innervated worms were 
conspicuous partners, the combination was evidently at the control of this active member which established itself on the passive member as ease or convenience may have directed; but continued such partnerships as established habits.

4. Complicated associations of three or more partners became fixed only in secondary faunas and evince predetermined procedures in selection.

5. In an early secondary fauna, casual or haphazard association which found one creature's struggle for food eased by the alimentary processes of another, led gradually to habitual association which eventually became a fixed habit and involved entire and lifelong dependence; created a parasitic state; transmitted this acquired habit from generation to generation; compelled modification of form in the parasite and unquestionably interfered with the alimentary functions of the host. This habitude of dependent parasitism lasted for millions of years and its culmination took place not at the period of the highest development of the offending organism but in the decline of the race when racial strength was failing; but it did occur at the climax of the host-species. There are evidences of a struggle on the part of the host-species to throw off the parasite by the erection of structural defenses for the obstructed function. The host-species came to a sudden end.

6. It appears to be evident that the members of the primitive fauna and flora, that is, of the first assemblage of life, were unimpaired by any "perturbation of normal activities."

7. The first and primitive division through the kingdom of life was just within the beginning, when the earthy materials breathed upon and infused with that interacting vibratory force (bion) which we call Life, became in progressive development in one part free from, and in the other part attached to the earth out of which both emerged. Thus came the chasm between the free animal and the dependent 
plant world; a division which cuts so deep it has never been bridged nor can be. Independence and dependence were established as the elemental and essential partition of the kingdom of life.

8. Individual and locomotive independence then, it would seem, has been the major function and prime determining factor in the progress of life. We find even in the plant world, fettered as it is, the effort to get free or to develop along the lines of the animals as shown in the development of specialized functions to which we have referred. But the plants never have got free. Their dependence is incurable under Nature's codex. All progress in life, as reckoned in terms of man, has come through independence and through those lines of animal life in which independence has been maintained at any cost. It is safe to say that none of the physical ancestors of man, however remote the direct line may have run, have ever surrendered their physical independence or suffered essential modification through perturbation of their normal activities.

9. Disease, then, in its broadest sense, so far as it means a disturbance of normal living, is a synonym of abnormal living; that is, of any life that has departed from the primitive impulse to a consistent, coördinated and fully competent physiology.

10. If dependence has affected and sealed the fate of one great division of the Kingdom of Life, so that it is and must remain subsidiary to the larger purposes of nature, dependence also has entered upon, invaded and degenerated a very large part, indeed, probably the major part of the other, the animal world. Here it seems to us that the dependent condition thus enforced is of a different order of quality than the aboriginal dependence of the plant world. Dependent races of animals have sought or accepted dependence as an easier mode of living, either waiting upon the unconscious forces of Nature, waves and winds, or on the normal activities of other animals. Such dependence 
has entered in some degree upon all primitive stocks of animal life and from such racial dependence there has been no escape. The lines in the animal world along which links in the chain of advancement have continued unbroken, are but few; the rest have run out into culs-de-sac where all hope is abandoned. Their expressions are about us on all sides. Neither barnacle nor brachiopod shows any tendency, after the ages, to return to its original independence.

11. It is thus emphatically true, in Nature's program, that physical salvation is of the few and is the reward only of righteous living.

12. We must not try to escape the conclusion that microbic disease is an abnormal adjustment in which the parasite lives its own dependent career at the cost of the host. The disease is of the host,-our friend suffers from tuberculosis,-but the life of the parasite though fully adjusted is still abnormal. For we have now evidence that the bacteria were in their inception free and independent. Their dependence is an acquisition of time. "Benign" or "malignant," from our point of view, there is little place for belief that either will change its adjustment.

13. For dependent races of life there has been no rescue or return. For dependent species, we are not so sure, but the present evidence is not very favorable. We have intimated for the case of the crinoid and the gastropod that the former may have exerted its comprehending defensive power to drive its parasite away. Frequently a host encysts its parasite by building up a protective wall about it. To get rid of a parasite is not, however, to cure the parasite habit.

14. Rescue of dependents is therefore not a part of the scheme of Nature, except through the exercise of intelligence. In Nature's plan of evolution dependents of all sorts are negligible and abandoned to hopelessness, save as gradually developing psychic factors intervene. 
To the thoughtful person who concedes that the physical and the intellectual functions of man can be apprehended only in the light of their historic development and through an understanding of their vast ancestry; who grants that the laws of life are uniform and effect the same governance whether in man or the insect; and who sees that the reading of the law is clearest where the tablet on which it is inscribed is least obscured, in its simplest manifestation rather than in its most complicated effects; to such as these the data and conclusions here should prove operative arguments. To those who have accustomed themselves rather to deductive thinking, who have been wont to conceive that the nature of man is to be construed from subjective and projected conceptions of what ought to be in order to conform to an introspectional standard; those who have not yet fully learned their subjection to Nature's laws, are engrossed with the passing interpretations of social problems, with expediences of the statute and the cares of the world; to these should go the assurance that in greater measure than they may have suspected the clue to human destiny and social adjustment lies concealed in the rocks beneath our feet. 
PRINTED IN THE UNITED States OF AMERICA 



